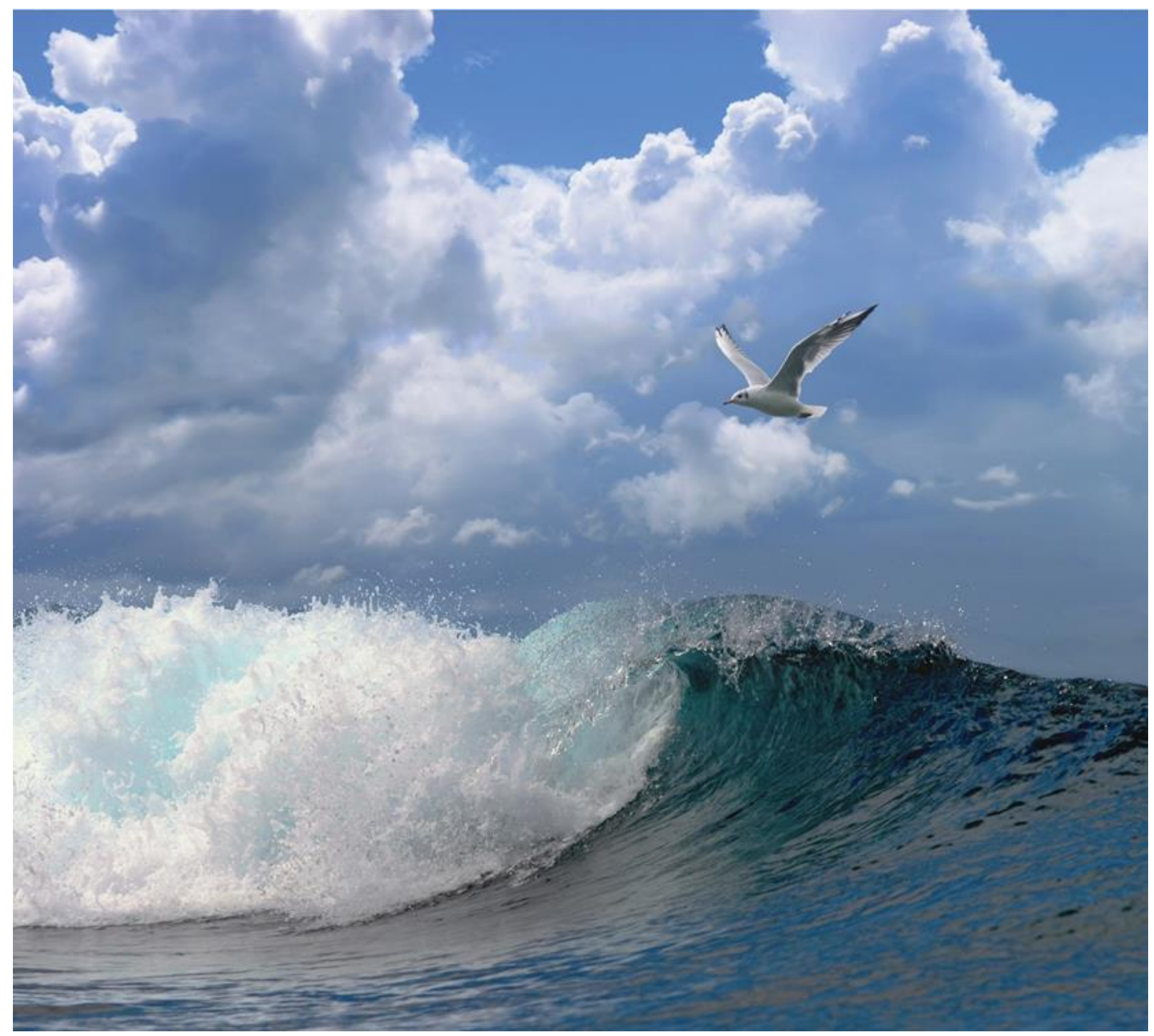

Bestandsoverzicht van snoekbaars, baars, blankvoorn en brasem in het IJssel/Markermeer 


\section{Bestandsoverzicht van snoekbaars, baars, blankvoorn en brasem in het IJ ssel-/Markermeer}

Auteurs: $\quad$ Nicola Tien, Tessa van der Hammen en J osien Steenbergen

Publicatiedatum: 19 maart 2018

Dit onderzoek is uitgevoerd door Wageningen Marine Research in opdracht van en gefinancierd door het Ministerie van Economische Zaken, in het kader van het Beleidsondersteunend onderzoekthema “Natuurinclusieve visserij” (projectnummer BO-43.023.02-002)

Wageningen Marine Research, IJ muiden maart 2018

Wageningen Marine Research rapport C018.18 
Nicola Tien, Tessa van der Hammen en J osien Steenbergen, 2018, . Bestandsoverzicht van snoekbaars, blankvoorn en brasem in het IJ ssel-/Markermeer. Wageningen Marine Research Wageningen UR (University \& Research centre), Wageningen Marine Research rapport C018/18, 63 pagina's.

Opdrachtgever: Ministerie van Landbouw, Natuur en Voedselkwaliteit

T.a.v.: Henk Offringa

Postbus 20401

2500 EK Den Haag

BAS code BO-43.023.02-002

Dit rapport is gratis te downloaden van https://doi.org/10.18174/444372

Wageningen Marine Research verstrekt geen gedrukte exemplaren van rapporten.

Wageningen Marine Research Wageningen UR is ISO 9001:2008 gecertificeerd.

\section{(c) 2016 Wageningen Marine Research Wageningen UR}

Wageningen Marine Research, onderdeel van Stichting Wageningen Research KvK nr. 09098104,

IMARES BTW nr. NL 8113.83.696.B16

Code BIC/SWIFT address: RABONL2U

IBAN code: NL 73 RABO 0373599285
De Directie van Wageningen Marine Research is niet aansprakelijk voor gevolgschade, noch voor schade welke voortvloeit uit toepassingen van de resultaten van werkzaamheden of andere gegevens verkregen van Wageningen Marine Research opdrachtgever vrijwaart Wageningen Marine Research van aanspraken van derden in verband met deze toepassing.

Dit rapport is vervaardigd op verzoek van de opdrachtgever hierboven aangegeven en is zijn eigendom. Niets uit dit rapport mag weergegeven en/of gepubliceerd worden, gefotokopieerd of op enige andere manier gebruikt worden zonder schriftelijke toestemming van de opdrachtgever. 


\section{Inhoud}

$\begin{array}{ll}\text { Samenvatting } & 5\end{array}$

$\begin{array}{lll}1 & \text { Inleiding } & 7\end{array}$

$\begin{array}{lll}1.1 & \text { Beleidsdoelstelling en vraag aan Wageningen Marine Research } & 7\end{array}$

$\begin{array}{ll}1.2 & \text { Aanpak }\end{array}$

2 Methodiek 9

2.1 Ontwikkelingen in de bestandsgrootte 9

$\begin{array}{ll}2.2 & \text { Ontwikkelingen in de bestandsopbouw } \\ & 10\end{array}$

$\begin{array}{lll}2.3 & \text { Vangstopbouw } & 10\end{array}$

$\begin{array}{lll}2.4 & \text { Stock-recruitment relatie } & 11\end{array}$

3 Baars $\quad 12$

3.1 Ontwikkelingen in de bestandsgrootte 12

3.2 Ontwikkelingen in de bestandsopbouw 13

$\begin{array}{lll}3.3 & \text { Vangstopbouw } & 14\end{array}$

$\begin{array}{lll}\text { 3.3.1 } 101 \mathrm{~mm} \text { staandwantvisserij } & 14\end{array}$

$\begin{array}{ll}\text { 3.3.2 Staandwantvisserij 130-190 mm en zegenvisserij } & 15\end{array}$

$\begin{array}{lll}3.4 & \text { Discussie } & 16\end{array}$

$\begin{array}{lll}4 & \text { Snoekbaars } & 17\end{array}$

$\begin{array}{lll}4.1 & \text { Ontwikkelingen in bestandsgrootte } & 17\end{array}$

$\begin{array}{ll}4.2 & \text { Ontwikkelingen in bestandsopbouw } \\ & 18\end{array}$

$\begin{array}{lll}4.3 & \text { Vangstopbouw } & 19\end{array}$

$\begin{array}{lll}\text { 4.3.1 Staandwant } 101 & 19\end{array}$

$\begin{array}{ll}\text { 4.3.2 Staandwant 130-190 en zegenvisserij } & 20\end{array}$

$\begin{array}{lll}4.4 & \text { Discussie } & 21\end{array}$

$5 \quad$ Blankvoorn $\quad 22$

5.1 Ontwikkelingen in bestandsgrootte 22

5.2 Ontwikkelingen in bestandsopbouw 23

5.3 Vangstopbouw 24

5.3.1 Staandwant $101 \quad 24$

$\begin{array}{ll}\text { 5.3.2 Staandwant 130-190 en zegenvisserij } & 25\end{array}$

$\begin{array}{lll}5.4 & \text { Discussie } & 26\end{array}$

6 Brasem $\quad 27$

$\begin{array}{lll}6.1 & \text { Ontwikkelingen in bestandsgrootte } & 27\end{array}$

6.2 Ontwikkelingen in bestandsopbouw 28

6.3 Vangstopbouw 29

6.3.1 Staandwant $101 \mathrm{~mm} \quad 29$

6.3.2 Staandwant 130-190 en zegenvisserij 30

$\begin{array}{lll}6.4 & \text { Discussie } & 31\end{array}$

7 Conclusies $\quad 32$

$\begin{array}{lll}7.1 & \text { Ontwikkelingen vanaf } 1992 & 32\end{array}$

7.2 Ontwikkelingen vanaf 2015

$\begin{array}{lll}7.3 & \text { Discussiepunten } & 33\end{array}$ 
7.3.3 Visserij-adviezen in de toekomst

7.3.4 Aanbevolen nader onderzoek

7.3.5 Enquête Beroepsvissers.

Literatuur

Verantwoording

Bijlage 1 Beschikbare gegevens

Bijlage 2 Opwerking gegevens openwatersurvey

Bijlage 3 Aantal gevangen vissen in de openwatersurvey

Bijlage 4 Biomassa-index-waardes

Bijlage 5 Betrouwbaarheidsintervallen van de relatie tussen het vangstsucces van de verhoogde boomkor en grote kuil 


\section{Samenvatting}

Het Ministerie van Landbouw, Natuur en Voedselkwaliteit is in het kader van de visserijwet verantwoordelijk voor duurzame visserij op snoekbaars, baars, blankvoorn en brasem en wil komen tot duurzaam visserijbeheer. Voor alle vier bestanden is de beleidsdoelstelling sinds visseizoen 2017/2018 geformuleerd in het document "Toekomstbeeld visstand IJ sselmeer/Markermeer synthesedocument". Hierin wordt gestreefd naar 'een evenwichtiger lengte-opbouw van de bestanden met meer grotere exemplaren en een groter aantal jaarklassen', als ook 'een toename van de (paai)bestanden'. Het ministerie van LNV wil de ontwikkeling van de vier bestanden nauwgezet volgen, om te kijken of de beoogde verbeteringen in de bestanden plaatsvinden.

Dit rapport geeft een overzicht van de bestandsontwikkelingen sinds 1992. De nadruk ligt op de ontwikkeling van de bestanden sinds het aangepaste beheer (bestaand uit hoofdzakelijk verminderde toegestane inspanning in staandwant- en zegenvisserij) in visseizoen 2014/2015. De vraag is, of sinds het aangepaste beheer verbeteringen in het bestand te zien zijn, in bestandsgrootte en bestandsopbouw. Daarnaast wordt de situatie in de laatste jaren vergeleken met de situatie vanaf 1992, om een indruk te krijgen van de potentie in het systeem, wat betreft 'herstel van de situatie met een visstand met een omvang en samenstelling die past bij de draagkracht van het systeem'. Er kan niet direct naar het effect van het veranderde beheer op de visbestanden worden gekeken; daarvoor zou informatie over de visserij-inspanning door de jaren heen nodig zijn. Deze informatie is niet beschikbaar. Met de momenteel beschikbare informatie kan alleen bekeken worden of sinds de verandering in visserijbeheer de bestanden positieve - of in ieder geval geen negatieve - trends laten zien. In welke mate een trend door enkel visserij of ook door andere factoren gestuurd wordt, is momenteel niet te achterhalen.

\section{Ontwikkelingen vanaf 1992}

Over de periode 1992-2017 vertonen alle vier bestanden negatieve ontwikkelingen. Voor alle bestanden lijkt ook te gelden, dat de sterkste afname waargenomen wordt bij de oudere jaarklassen. Alle vier bestanden vertonen een dieptepunt qua bestandomvang en hoeveelheid grote vis in de periode vanaf 2012. Gezien de relatief slechte situatie vanaf 2012, zou herstel dus in ieder geval gericht moeten zijn op een verbetering naar een situatie voorafgaand aan deze periode.

\section{Ontwikkelingen vanaf 2015}

Alle vier bestanden laten in 2015-2017 geen consistente achteruitgang zien ten opzichte van de jaren ervoor (2012-2014). Ten opzichte van deze (slechte) voorgaande jaren laten sommige indices in met name 2016-2017 zelfs iets hogere waarden zien. Zo is de hoeveelheid oudere baars iets hoger dan in de jaren ervoor. Ook zijn er indicaties dat de hoeveelheid 1-jarige en oudere snoekbaars iets hoger is in 2015-2017 (alhoewel de onzekerheid wat betreft de indices voor oudere snoekbaars groot is). De paaibestandsomvang van blankvoorn gaat wel achteruit tot en met 2016, maar de index-waardes in 2017 zijn weer relatief positief. Brasem vertoont geen positieve ontwikkelingen vanaf 2015. Andere positieve signalen zijn dat de recruitment van baars, snoekbaars en brasem relatief hoog is in 2016 en/of 2017. Daarentegen zijn 2015-2017 slechte jaren qua recruitment van blankvoorn, met de laagste recruitment-waarde sinds 2000 in 2017.

De doelstelling van het beheer zoals ingestoken in visseizoen 2014/2015 was 'geen verdere achteruitgang'. Deze doelstelling lijkt in lijn met de situatie in het veld. Voor de huidige beheersdoelstelling ('herstel') zijn geen consistente signalen aangetroffen in de surveygegevens. Er lijken echter wel een paar kleine positieve ontwikkelingen te zijn in met name 2016 en 2017.

\section{Ontwikkelingen in aanlandingen en aanbevolen ecologisch onderzoek}

Omdat beroepsvissers signalen afgeven dat de trends zoals aangetroffen in de survey niet overeenkomen met de trends die zij in hun aanlandingen zien, zijn de survey-indices naast de aanlandingen gelegd. Hieruit blijkt dat dezelfde temporele patronen qua toe- en afname terug te zien zijn in de aanlandingen en de surveyvangsten van baars, blankvoorn en met name van snoekbaars. Alleen voor brasem is dit niet het geval.

Momenteel is door een gebrek aan visserijgegevens weinig bekend over de visserijsterfte. Het is de intentie om de komende jaren hier meer over te weten te komen, en deze informatie mee te nemen in 
eventuele visserij-adviezen. Behalve de visserijsterfte zijn er meer factoren die een rol spelen in de bestandsontwikkelingen, zoals ecologische interacties met andere soorten en veranderingen in de draagkracht van het systeem. Ook hierover is weinig bekend. Onderzoek dat leidt tot een beter begrip van het ecosysteem is sterk aan te raden. Ook deze informatie zou dan meegenomen kunnen worden bij het definiëren van beleidsdoelstellingen en het genereren van visserij-adviezen.

\section{Enquête beroepsvissers}

Evenals vorig jaar is het beeld van de vissers over de toestanden van de bestanden middels een enquête systematisch gebundeld. Samengevat zijn de vissers over het algemeen redelijk positief over de hoeveelheid schubvis in 2017 ten opzichte van 2016. De vissers zijn het meest positief over de toestand van baars in zowel het IJ sselmeer als het Markermeer, zowel voor de maatse als de ondermaatse baarzen. Ook de survey-indices wat betreft het gehele bestand en de maatse baarzen laten een toename van 2016 naar 2017 zien. De relatief hoge recruitment van snoekbaars die is waargenomen door de survey in 2017 lijkt niet door alle vissers te zijn waargenomen. Wel komt deze in de marktbemonstering naar voren. 


\section{$1 \quad$ Inleiding}

\subsection{Beleidsdoelstelling en vraag aan Wageningen Marine Research}

Het project dat ten grondslag ligt aan dit rapport is gericht op het beheer van vier commercieel beviste vissoorten in het IJ sselmeer en Markermeer; snoekbaars (Sander lucioperca), baars (Perca fluviatilis), blankvoorn (Rutilus rutilus) en brasem (Abramis brama). Het Ministerie van Landbouw, Natuur en Voedselkwaliteit (LNV) is in het kader van de visserijwet verantwoordelijk voor duurzame visserij en wil komen tot duurzaam beheer van deze schubvisbestanden.

De belangrijkste visserijen op deze bestanden zijn de zegen- en staandwantvisserij. In visseizoen 2014/2015 is het beheer omtrent deze twee visserijen aangepast: Het ministerie van EZ heeft voor het visseizoen 2014/2015 het volgende beheerplan geïmplementeerd: (a) de staandwantvisserij is beperkt tot $15 \%$ van de beschikbare inzet (in merkjes) per visser, (b) zegenvisserij op het openwater is beperkt tot 7 dagen per jaar en het aan elkaar knopen van zegennetten is niet meer toegestaan, (c) zegenvisserij in de havens is niet meer toegestaan en (d) vissen met grote fuik met ruif op blankvoorn in de (voor aalvisserij) gesloten periode is niet meer toegestaan. De beleidsdoelstelling hierbij was het voorkomen van verdere achteruitgang in de vier bestanden. Sinds visseizoen $2017 / 2018$ is de beleidsdoelstelling zoals geformuleerd in het document 'Toekomstbeeld visstand IJ sselmeer/Markermeer - synthesedocument'. Hierin wordt het gewenste toekomstbeeld geschetst op basis van de verplichtingen die volgen uit de visserijwet en de EU Kaderrichtlijn Water. In dit document wordt voorgesteld om:

"voor de vier commercieel beviste vissoorten een situatie na te streven waarbij binnen de geschetste termijn van ca. 15 jaar wordt toegewerkt naar een situatie waarbij sprake is van een evenwichtiger lengte-opbouw van de bestanden met meer grotere exemplaren en een groter aantal jaarklassen. Met de sturing hierop wordt tegelijk gerealiseerd dat wordt toegewerkt naar een toename van de (paai)bestanden en zal sprake zijn van een natuurlijker opbouw en samenstelling van de visstand. Hiermee wordt een stap gezet van de huidige behoudsdoelstellingen, naar een inzet gericht op een herstel van de situatie met een visstand met een omvang en samenstelling die past bij de draagkracht van het systeem."

Om dit te bewerkstelligen is voor visseizoen 2017/2018 het beheer (i) instandhouding van de sinds $2014 / 2015$ toegestane visserij-inspanning en (ii) een verlaging van de totale brasem- en blankvoornvangsten met 36\% ten opzichte van 2016/2017.

Het ministerie van LNV wil de ontwikkeling van de vier bestanden nauwgezet volgen, om te kijken of de beoogde verbeteringen in de bestanden plaatsvinden. Daarom is Wageningen Marine Research (WMR) gevraagd om een overzichtsrapportage van de bestandsontwikkelingen ${ }^{1}$.

\section{$1.2 \quad$ Aanpak}

Dit rapport geeft een overzicht van de bestandsontwikkelingen van snoekbaars, baars, blankvoorn en brasem in het IJ sselmeer en Markermeer sinds 1992. De nadruk ligt op de ontwikkeling van de bestanden sinds het aangepaste beheer in visseizoen 2014/2015. De vraag is, of sinds het aangepaste beheer verbeteringen in het bestand te zien zijn, in de bestandsgrootte en in de lengte/leeftijdopbouw van het bestand (i.e., de bestandsopbouw). Om de ontwikkelingen sinds het nieuwe beheer te evalueren worden de gegevens van 2015-2017 (i.e., de nieuwe beheersituatie) afgezet tegen de gegevens van de drie jaar ervoor (i.e., de oude beheersituatie). De survey in 2014 wordt bij de oude beheerssituatie genomen, omdat de survey is uitgevoerd in een periode (oktober-november) waarin de nieuwe beheerssituatie nog (vrijwel) geen invloed heeft kunnen hebben op de visserijdruk op de

\footnotetext{
${ }^{1}$ In de afgelopen jaren heeft Wageningen Marine Research visserij-adviezen gegeven over deze bestanden. Vanaf visseizoen 2017/2018 wordt het beheer geënt op plannen die zijn opgesteld door de PO IJsselmeer. Er worden dus geen adviezen gegeven in dit rapport.
} 
vier bestanden (zie voetnoot in hoofdstuk 10.2 en bijlage 9 van Tien et al. 2015 voor de uitwerking per visserij en bestand).

Hierbij moet wel in acht worden genomen dat er niet direct naar het effect van het veranderde beheer op de visbestanden kan worden gekeken; daarvoor zou informatie over de effectieve visserijinspanning door de jaren heen nodig zijn. Deze informatie is niet beschikbaar (zie bijlage 9 van Tien et al 2017 voor een beschrijving van de missende visserij-informatie). Daarnaast is een goed functionerend theoretisch model nodig, die de populatiedynamica en de invloed van de visserij erop beschrijft (zoals een analytisch bestandsschattingsmodel, zie Tien en van der Hammen 2015). Met de momenteel beschikbare informatie kan daardoor alleen bekeken worden of sinds de verandering in visserijbeheer de bestanden positieve - of in ieder geval geen negatieve - trends laten zien. In welke mate een trend door visserij of ook door andere factoren gestuurd wordt, is momenteel niet te achterhalen.

Daarnaast wordt de situatie in de laatste jaren vergeleken met de situatie vanaf 1992, om een grove indruk te krijgen van de potentie in het systeem, wat betreft 'herstel van de situatie met een visstand met een omvang en samenstelling die past bij de draagkracht van het systeem'. Bij gebrek aan meer kwantitatieve beleidsdoelstellingen en gebrek aan ecologische kennis over de draagkracht van het systeem kan voor deze doelstelling alleen de situatie nu op grote lijnen vergeleken worden met die in de decennia hiervoor. 


\section{$2 \quad$ Methodiek}

Er wordt hoofdzakelijk gewerkt met visgegevens die verzameld zijn in visserij-onafhankelijke surveys, i.e. bemonsteringsprogramma's die elk jaar op dezelfde manier worden uitgevoerd. Door deze eenduidige bemonsteringsmethodiek kan goed naar veranderingen in een bestand over de jaren heen gekeken worden. Er wordt dus gekeken naar trends.

Het bestand wordt op verschillende manieren geëvalueerd: veranderingen in de grootte van het bestand worden gevolgd, en veranderingen in de opbouw van het bestand. Hierbij wordt op twee tijdsschalen naar de trends gekeken (hoofdstuk 1.2).

- Hoe hebben de bestanden zich over de laatste decennia ontwikkeld?

- Hoe hebben de bestanden zich sinds 2015 ontwikkeld, vergeleken met de jaren ervoor (20122014)?

Daarnaast wordt met de eerste gegevens van de marktbemonstering (gestart eind 2016) een inschatting gemaakt van de wijze waarop de visserij ingrijpt op een bestand.

\subsection{Ontwikkelingen in de bestandsgrootte}

\section{De openwatersurvey vanaf 1992}

Om de ontwikkelingen in bestandsgrootte te evalueren wordt bij voorkeur gewerkt met een survey, die een representatieve index voor de hoeveelheid biomassa vis oplevert. Voor de vier schubvissoorten in het IJ sselmeer/Markermeer is de best beschikbare survey de actieve monitoring op het open water (de 'openwatermonitoring') met de grote kuil/verhoogde boomkor en met de elektrokor (Tien et al. 2017). Zie bijlage 1 voor een beschrijving van de survey.

De berekende survey-index heeft betrekking op het vangstsucces in de survey; de gemiddelde hoeveelheid gevangen biomassa per hectare bevist oppervlak. Zie bijlage 2 voor een beschrijving van de methodiek van opwerking van de surveygegevens naar survey-indices. Er zijn twee indices wat betreft bestandsgrootte berekend:

1. survey-index voor het totale bestand, waarbij de biomassa van alle gevangen vis is meegenomen

2. survey-index voor het paaibestand, waarbij de biomassa is meegenomen van de vis die langer is dan de $L_{50 \%}$, i.e. de vis bij lengtes waarvan minimaal de helft paairijp (adult) is.

De indices worden vanaf 1992 berekend en niet vanaf het begin van de surveys (1966), omwille van twee redenen. Ten eerste was de kuilsurvey tot 1989 niet gestandaardiseerd. Hierdoor kan geen goede schatting van de index-waarde voor deze jaren worden gegeven. Ten tweede vonden tot de jaren 90 veel veranderingen in de nutriëntenhuishouding van beide meren plaats, waarbij sinds de jaren 90 een redelijk stabiel niveau is bereikt (Noordhuis et al. 2014). Veranderingen in de nutriëntenhuishouding kunnen een grote invloed hebben op de potentiële maximale bestandsomvang (de draagkracht), als ook op het doorzicht in het water (en daardoor de vangbaarheid in de survey).

\section{Een representatieve biomassa-index}

Bij het gebruik van de biomassa-index wordt aangenomen dat de trend in de survey-gevangen vis representatief is voor de ontwikkelingen in de bestandsgrootte. De openwatersurvey is echter opgezet om de kleine, jonge vis te monitoren. De grotere oudere vis wordt mogelijk minder goed gevangen in de survey maar in welke mate is onbekend. Daarom is onderzocht of de survey in staat is om een jaarklasse vis adequaat te volgen door de jaren heen (Tien et al. 2017, en een samenvatting hier in bijlage 2). Zoals verwacht was de relatie tussen de hoeveelheid 0 -jarige vis en de hoeveelheid 1 -jarige vis het jaar erop slecht, voor alle bestanden. Dit wordt verwacht omdat de sterfte van 0 -jarige vis relatief zeer hoog en variabel is. Voor de relatie tussen oudere vis (bijvoorbeeld 1-jarige vis en 2-jarige vis het jaar erop) werden wel significante relaties gevonden voor baars, brasem en blankvoorn. De survey lijkt dus een representatief beeld te geven van de ontwikkelingen in de bestandgrootte van vis van 1 jaar en ouder. Echter, voor snoekbaars werden geen significante relaties gevonden voor 1-jarige en oudere vis. Snoekbaars ouder dan 0 jaar wordt in zeer lage 
aantallen gevangen in de survey (bijlage 3), waardoor het niet mogelijk is om nauwkeurig trends in afzonderlijke jaarklassen van dit bestand te volgen. Bij de interpretatie van de trends van 1-jarige en oudere snoekbaars moet dus rekening worden gehouden met deze onnauwkeurigheid van de gegevens.

\section{De invloed van doorzicht op de biomassa-index}

Verhoogd doorzicht van het water kan betekenen dat een vis het surveytuig ziet aankomen en daardoor een grotere kans heeft om te ontkomen. Als het doorzicht verbetert door de jaren heen, kan dit vervolgens leiden tot een verlaagd vangstsucces in de survey, terwijl het bestand mogelijk niet is afgenomen. De toevoer in hoeveelheid nutriënten in het IJ sselmeer en Markermeer is afgenomen sinds de jaren 70 van de vorige eeuw. Dit zou mede geleid kunnen hebben tot verhoogd doorzicht in het water en vervolgens een negatief effect gehad kunnen hebben op het vangstsucces in de survey door de jaren heen. Binnen de vangstadviezen zoals tot nu toe opgesteld, is hier rekening mee gehouden door de jaren met de grootste afname in nutriëntentoevoer niet mee te nemen in de analyses, waardoor voor de analyses niet met gegevens van voor 1992 wordt gewerkt. Echter, ook sinds 1992 is de toevoer in nutriënten iets afgenomen (Noordhuis et al. 2014). Daarom is het effect van doorzicht op het vangstsucces van de vier soorten in de openwatersurvey in deze periode statistisch onderzocht (samen met de invloed van locatie, jaar en tuig). Deze analyse staat beschreven in Bijlage 4 van (Tien et al. 2017).

Uit deze analyse blijkt dat doorzicht inderdaad een negatief effect heeft op het vangstsucces: hoe helderder het water, hoe minder vissen je vangt. Echter, ook blijkt dat door de jaren heen het gemiddelde doorzicht tijdens de survey sinds 1992 maar heel weinig is toegenomen en verwaarloosbaar is vergeleken met de verschillen in doorzicht binnen een jaar. Er is dus een groot verschil in doorzicht tussen locaties en dagen, en relatief weinig tussen jaren. De toenemende doorzicht door de jaren heen heeft ook vrijwel geen effect op de uitkomsten van het statistisch model: als doorzicht niet zou veranderen door de jaren heen, wordt vrijwel geen andere trend in vangstsucces voorspeld.

Samengevat bleek uit de analyses (Tien et al. 2017) dat doorzicht vrijwel geen rol speelt in de temporele veranderingen in de index sinds 1992. Er wordt daarom in de verdere opwerking geen rekening gehouden met verschillen in doorzicht. Wel zijn de ontwikkelingen in doorzicht tijdens de survey bijgehouden (bijlage 1). Hieruit blijkt dat het doorzicht in 2017 lager ligt dan in de jaren ervoor. Het doorzicht neemt dus niet consistent toe door de jaren heen.

\subsection{Ontwikkelingen in de bestandsopbouw}

De openwatermonitoring geeft ook informatie over de ontwikkelingen in de bestandsopbouw van het bestand; verandert de lengte-opbouw van een bestand door de jaren heen? Hierbij geldt dat de informatie alleen gebruikt moet worden voor een beeld van de jaar-op-jaar veranderingen in de lengte-opbouw. Het is niet geschikt om naar de absolute verhouding tussen lengtes te kijken, aangezien de vangstefficiëntie van de survey waarschijnlijk verschilt tussen lengtes.

Met behulp van lengte-leeftijd-sleutels (zie bijlage 2 ) is de lengte-opbouw van de openwatermonitoring vertaald in een leeftijdsopbouw. Zodoende kunnen ontwikkelingen in de leeftijdsopbouw door de jaren heen gevolgd worden. Dit wordt op twee manieren benaderd: (i) door de survey-indices per leeftijdsklassen te volgen en (ii) door de verdeling van biomassa over leeftijden heen te volgen. Met de tweede manier kan de ontwikkeling in met name de grotere leeftijden in meer detail bekeken worden.

\subsection{Vangstopbouw}

I dealiter zou ook de ontwikkeling in de visserijsterfte bekeken worden, om de impact van de visserij op de bestanden te evalueren. Echter, het is momenteel nog niet mogelijk om de visserijsterfte te schatten. Het belangrijkste gemis hierbij is een tijdreeks van de vangst en inspanning van de visserij. Daarnaast moeten nog bestaande modellen aangepast worden, om visserijsterfte te schatten voor specifiek de visserij op het IJ ssel/-Markermeer. Voor een beschrijving van de visserij op de vier schubvissoorten, wordt verwezen naar bijlage 9 van Tien et al. (2017). 
Wel is nieuwe informatie over de lengte- en leeftijdsopbouw van de commerciële vangsten van de staandwantvisserij met $101 \mathrm{~mm}$ maaswijdte beschikbaar. Met deze informatie kan een eerste inschatting worden gemaakt van de wijze waarop de visserij ingrijpt op een bestand: welke leeftij dscategorieën worden het meeste onttrokken?

De overige visserijen (staandwantvisserij met grotere mazen en zegenvisserij) werden tot nu toe weinig bemonsterd in de marktbemonstering zodat alleen een kwalitatieve, eerste indruk van de onttrekking gegeven kan worden. Er is een vistrip met warrelnetten beschikbaar ( $130 \mathrm{~mm}$ met ladders), een vistrip met gemengde maaswijdte (130 en $190 \mathrm{~mm}$ ) en een vistrip met de zegenvisserij.

\section{$2.4 \quad$ Stock-recruitment relatie}

Naast de analyses in hoofdstukken 3-6, is in bijlage 6 een analyse van de stock-recruitment relatie opgenomen. Hiermee wordt onderzocht of er signalen in de surveygegevens zijn, voor het risico op recruitment impairment; een situatie waarbij de aanwezige adulten niet de maximale hoeveelheid aanwas kunnen produceren. Dit zou betekenen dat herstel van het bestand belemmerd zou kunnen zijn. 


\section{$3 \quad$ Baars}

\subsection{Ontwikkelingen in de bestandsgrootte}

De index voor het paaibestand (figuur 3.1a) laat over de tijdreeks heen een dalende trend zien. Het dieptepunt ligt in 2011-2015. Het jaar 2015 heeft de laagste index-waarde van de gehele tijdreeks, gevolgd in 2016 door de hoogste index-waarde sinds 2004. Samengevat is na een langdurige afname in paaibiomassa, sinds 2015 een sterk fluctuerende trend te zien, nog zonder consistente toe- of afname.

De index van het gehele bestand laat over de gehele tijdreeks geen duidelijke trend zien, maar wel een relatief lage bestandsgrootte tussen 2004-2012 zien. Deze wordt gevolgd door een toename in bestandsgrootte vanaf 2013 (figuur 3.1b). Dit valt samen met de tuigwisseling, (van grote kuil naar verhoogde boomkor), waarvan de effecten onzeker zijn (bijlage 5). Om deze onzekerheid buiten beschouwing te laten, wordt de trend vanaf 2015 vergeleken met de jaren 2013-2014, waarin ook al met de boomkor werd gevist. De index sinds 2015 verschilt niet sterk van de index in 2013-2014. Wel is de index in 2017 de hoogste sinds 2013. Dit wordt niet veroorzaakt door toegenomen paaibiomassa (zie figuur 3.1a), maar door toegenomen juveniele biomassa.

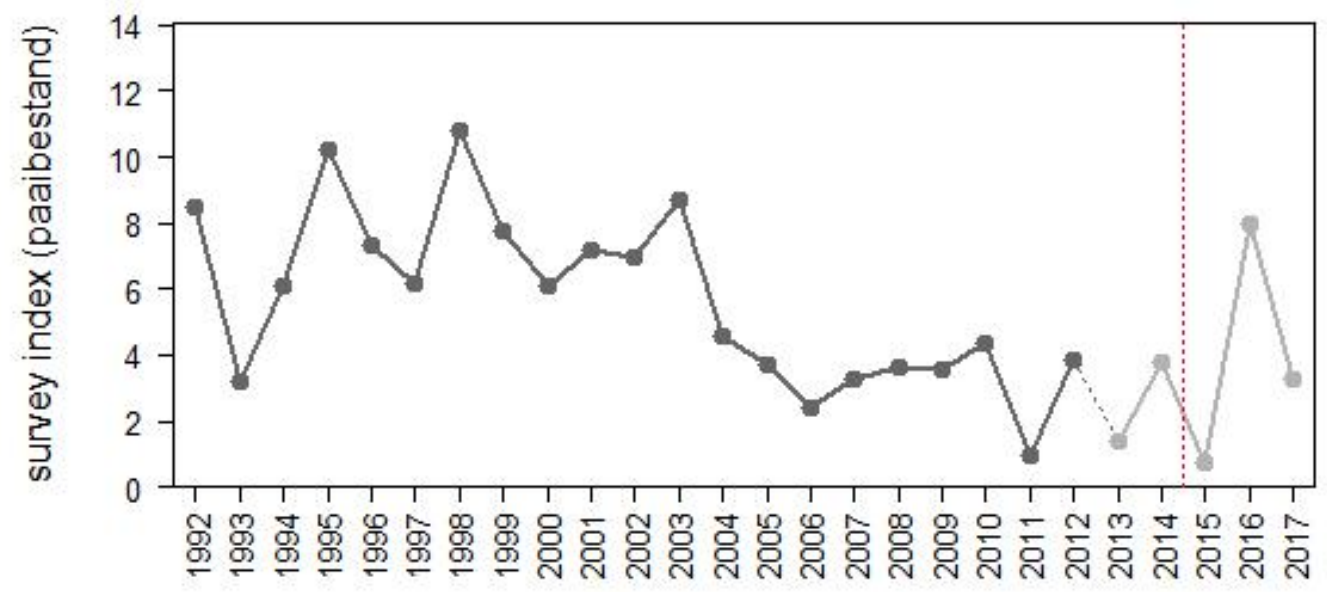

(a)

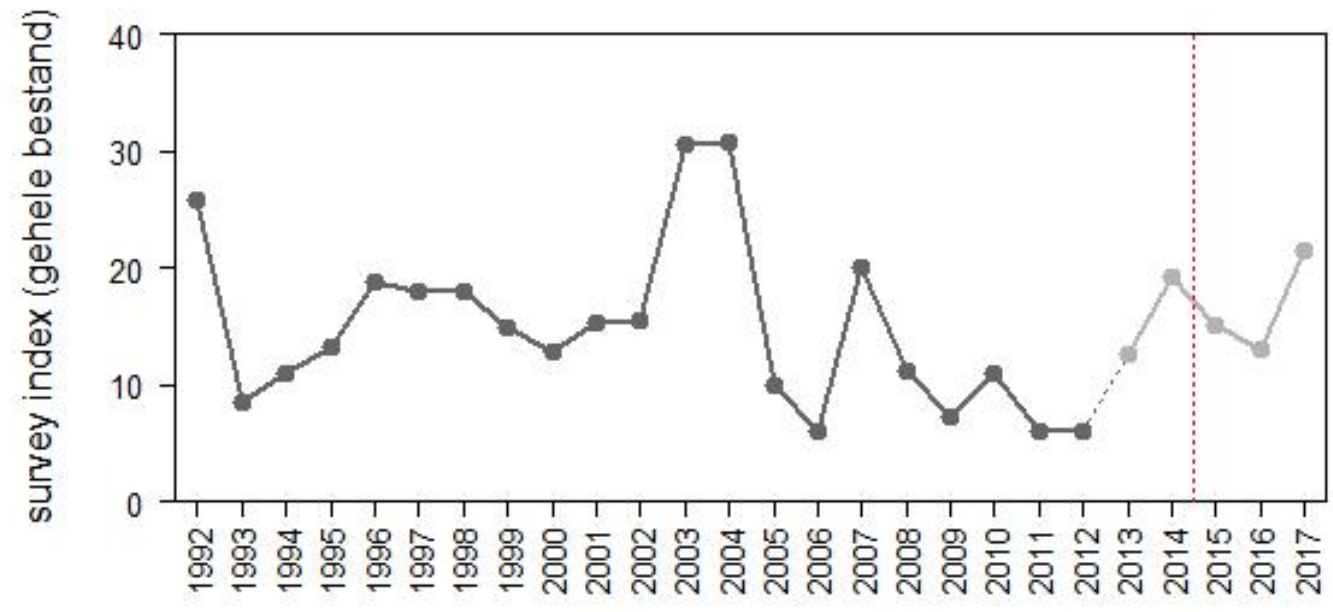

(b)

Figuur 3.1 Biomassa-index voor baars, boven (a) voor het paaibestand, en beneden (b) voor het gehele bestand. Trend voor het IJ sselmeer en Markermeer gecombineerd. De biomassa-indices betreffen de gemiddelde biomassa-dichtheid (kilogram per hectare) van de openwatersurvey (kuil/boomkor en elektrokor survey in de verhouding 0.7:0.3). De rode lijn geeft de start van het huidige visserijbeheer weer. Van 2012 op 2013 is in de kuil/boomkor survey gewisseld van tuig, van grote kuil naar verhoogde boomkor. De achterliggende getallen staan in bijlage 4 . 


\subsection{Ontwikkelingen in de bestandsopbouw}

Er worden door de tijdserie heen minder grote baarzen gevangen in de survey (figuur 3.2). Waar in het begin van de tijdreeks nog veel baarzen van 30-31 cm worden aangetroffen, zijn er vanaf 2011 bijna geen baarzen groter dan $25 \mathrm{~cm}$ gevangen. Het minste aandeel grotere vissen wordt aangetroffen in 2015. Echter, in 2016 en 2017 worden er weer meer grote baarzen gevangen.

De recruitment (0-jarige vis) fluctueert sterk tussen jaren zonder duidelijke trend (figuur 3.3). Vanaf 2013 is de recruitment relatief hoog, met uitzondering van 2016. Zoals in hoofdstuk 3.1 besproken is een invloed van de tuigwissel niet uitgesloten. Ook de index van 1-jarigen fluctueert sterk. Tussen 2006-2017 lijkt de index rond een lager niveau te fluctueren, met een sterke piek in 2016. De hoeveelheid oudere vis (de 2-jarige en de 3-jarige en oudere vis) neemt sinds de eeuwwisseling zeer sterk af. Sinds 2016 lijkt de hoeveelheid 2-jarigen iets hoger te liggen. Hoe ouder de vis, hoe eerder en sterker de afname is.

De relatieve biomassaverdeling over de leeftijden (alles behalve de 0 -jarigen, figuur 3.4) laat zien dat voor de eeuwwisseling grofweg de helft van de biomassa, uit baars van minimaal 2 jaar oud bestond. Dit aandeel oudere baars is afgenomen na de eeuwwisseling.

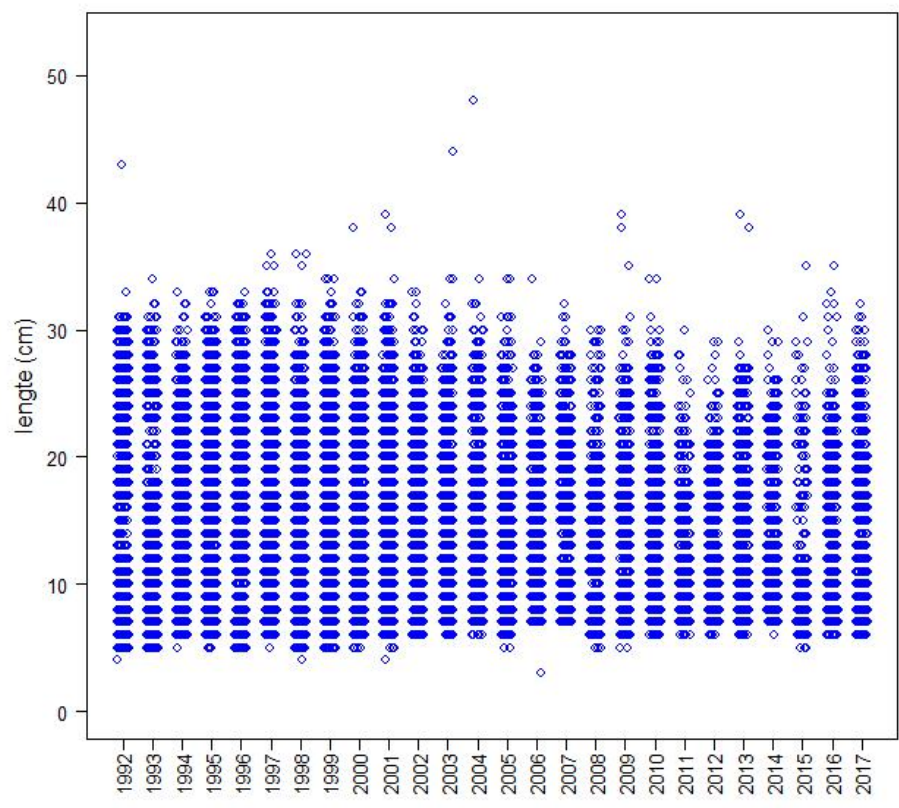

Figuur 3.2 Plot van de lengtes van alle baarzen (blauwe cirkels) gevangen in de openwatersurvey met kuil/ boomkor/ elektrokor door de jaren heen. Eén blauwe cirkel kan meerdere vissen representeren. 

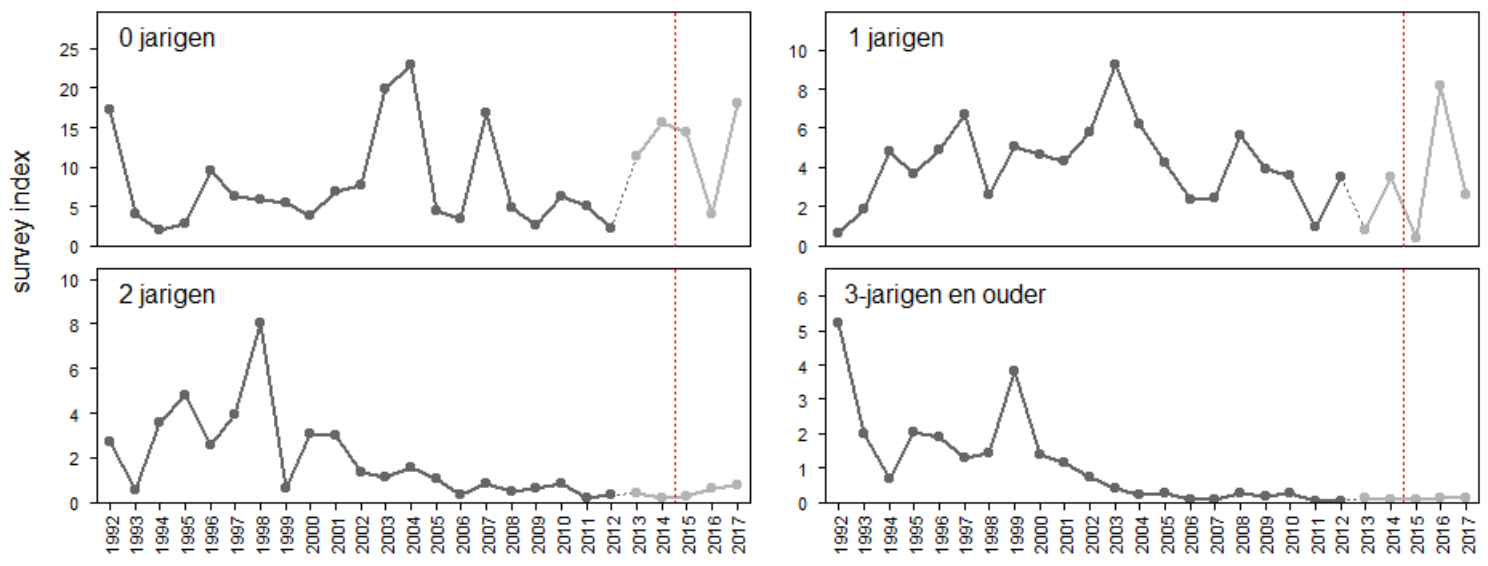

Figuur 3.3 Biomassa-index voor baars, opgesplitst in leeftijden. Trend voor het IJ sselmeer en Markermeer gecombineerd. De biomassa-index betreft de gemiddelde biomassa-dichtheid ( $\mathrm{kg}$ per hectare) van de openwatersurvey (kuil/boomkor en elektrokor survey in de verhouding 0.7:0.3). De rode lijn is de start van het nieuwe visserijbeheer. Van 2012 op 2013 is in de kuil/boomkor survey gewisseld van tuig, van grote kuil naar verhoogde boomkor.

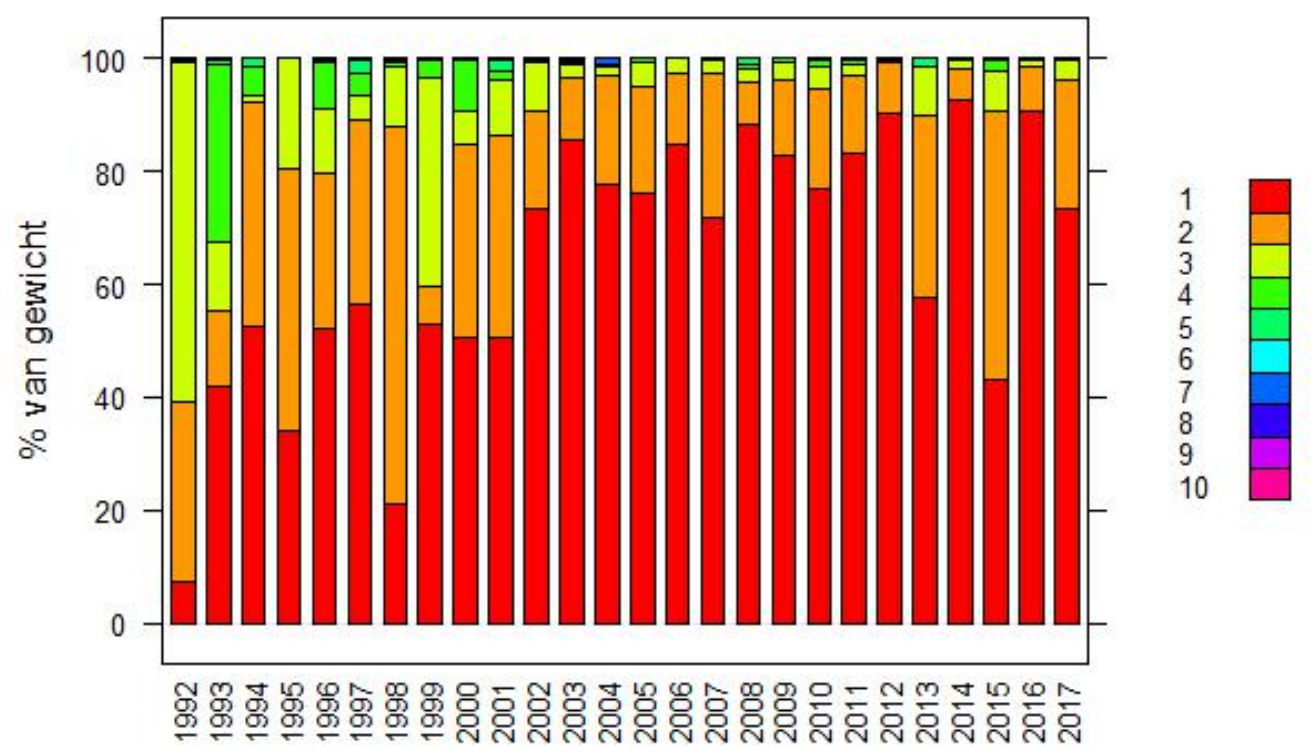

Figuur 3.4 Leeftijdsopbouw van baars (zonder de 0 -jarige) gevangen in de openwatersurvey met de kuil/ boomkor en de elektrokor door de jaren heen. Het percentage van het gewicht per leeftijdsklasse. Van 2012 op 2013 is gewisseld van tuig, van grote kuil naar verhoogde boomkor.

\subsection{Vangstopbouw}

\subsection{1 $101 \mathrm{~mm}$ staandwantvisserij}

De lengte-opbouw van de vangsten van commerciële staandwantnetten met $101 \mathrm{~mm}$ in de marktbemonstering van september-december 2016 en 2017 toont weinig ondermaatse baars (figuur 3.5): 4-6\% van het aantal gevangen baars is ondermaats. Bijna alle vangst van de 101-netten is bovenmaats. Alhoewel de minimum aanlandingsmaat $22 \mathrm{~cm}$ is, wordt baars pas vanaf $27 \mathrm{~cm}$ beduidend gevangen in deze visserij. Er worden hoofdzakelijk baarzen van 2-3 jaar oud gevangen (figuur 3.6). Dit zijn leeftijdsklassen die een sterke afname in bestandsomvang hebben laten zien in de tijdreeks. Wel heeft vrijwel alle baars van 2-3 jaar al gepaaid. 


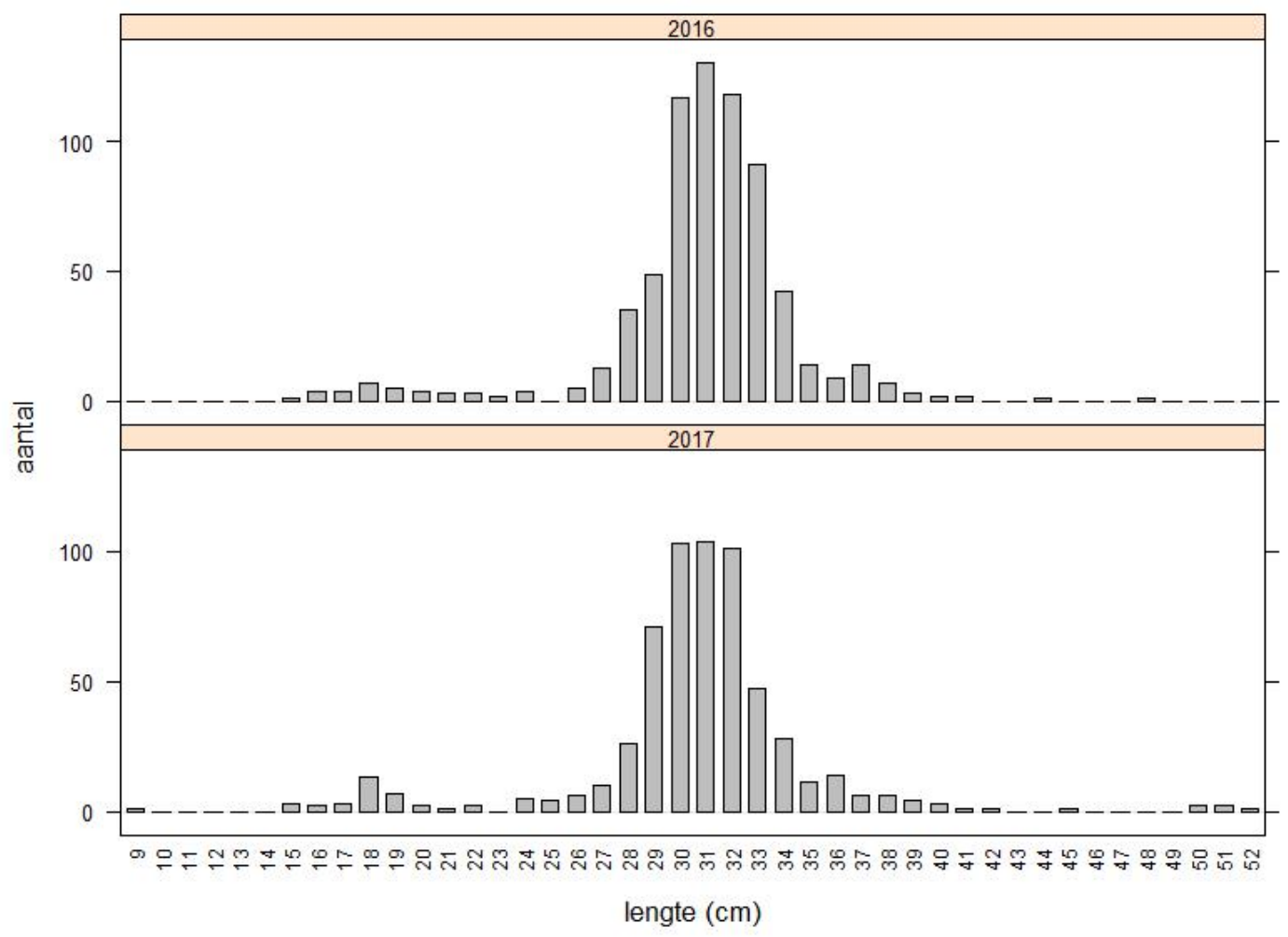

Figuur 3.5 Lengteopbouw van de commerciële baarsvangsten met staandwantnetten 101 $\mathbf{m m}$, bemonsterd in de marktbemonstering in september-december van 2016 en 2017. Baars mag worden aangeland vanaf $22 \mathrm{~cm}$.

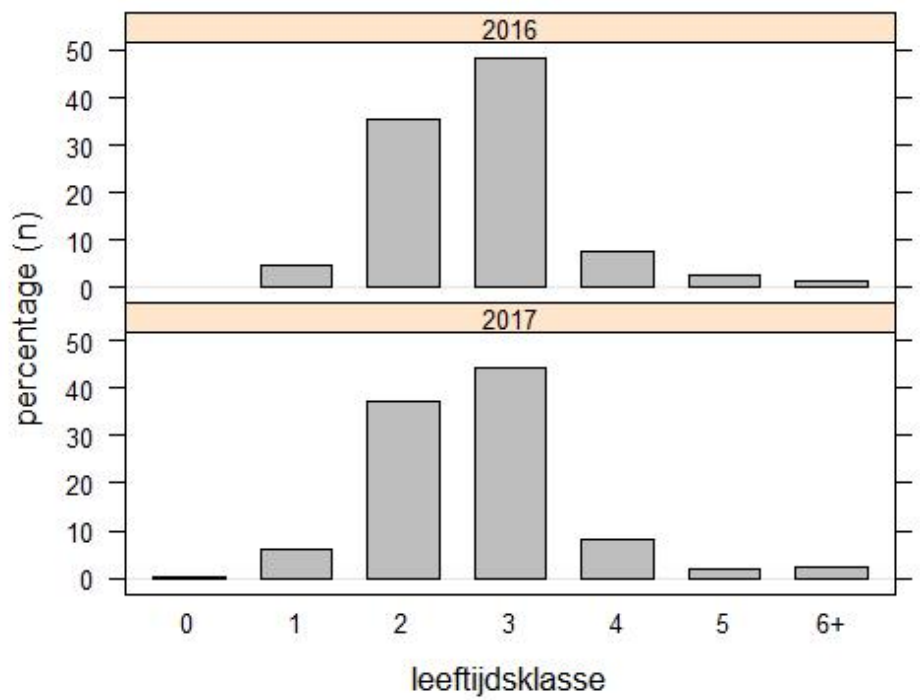

Figuur 3.6 Geschatte leeftijdsopbouw van de commerciële baarsvangsten met staandwantnetten $101 \mathrm{~mm}$, bemonsterd in de marktbemonstering in september-december van 2016 en 2017. De y-as geeft het geschatte percentage van het totaal aantal vissen weer.

\subsubsection{Staandwantvisserij $130-190 \mathrm{~mm}$ en zegenvisserij}

In de twee visreizen met grotere maaswijdtes zijn maar 11 baarzen gevangen. Het betrof vooral baars van 4 jaar en ouder. In de visreis met zegenvisserij is geen baars gevangen. 


\subsection{Discussie}

De index voor de gehele bestandsgrootte vertoont geen consistente afname over de tijdreeks heen, maar is wel tussen 2004 en 2013 relatief laag. De hoeveelheid paairijpe baars neemt wel over de gehele tijdreeks heen af, met het dieptepunt in 2015. 2016 was bij uitzondering een jaar met relatief veel adulten (dit waren voornamelijk 1-jarigen), maar 2017 is terug op het niveau van de jaren ervoor. De grote groep 1-jarigen is maar voor een klein deel 2-jaar geworden in 2016. De afname in bestandsomvang lijkt hoofdzakelijk plaats te vinden bij de grotere baarzen; hoe groter/ouder de baars, hoe sterker de afname door de tijdreeks heen.

De situatie vanaf 2015, na de veranderingen in het visserijbeheer, toont geen consistente verbetering ten opzichte van 2013-2014: de index voor de paaibiomassa is, na een relatief sterk jaar in 2016, in 2017 weer gedaald tot het niveau van de jaren ervoor. Ook wat betreft de totale bestandsgrootte lijkt de situatie vanaf 2015 niet erg verschillend ten opzichte van 2013-2014. De bestandsopbouw lijkt in 2016 en 2017 uit relatief meer 2-jarigen te bestaan. Ook is de hoeveelheid recruitment relatief hoog in 2017.

Ter conclusie, de bestandsgrootte lijkt weinig veranderd sinds 2015. Echter, de bestandopbouw lijkt iets te verbeteren, met enigszins meer oudere, grotere vis in 2016 en 2017 in vergelijking met de jaren er direct voor. 


\section{$4 \quad$ Snoekbaars}

\subsection{Ontwikkelingen in bestandsgrootte}

De index voor het paaibestand (figuur 4.1a) laat in de gehele tijdreeks lage waardes zien, omdat er weinig grote snoekbaarzen worden gevangen in de survey. Er zijn echter wel uitschieters naar boven tot en met 2002. Zulke pieken worden vanaf 2003 niet meer aangetroffen. In 2011-2014 wordt vrijwel geen paairijpe snoekbaars meer aangetroffen in de survey (bijlage 3). In 2015-2017 ligt de paaibestandsindex weer wat hoger dan de drie jaren ervoor.

De survey-index voor het gehele bestand neemt vanaf de eeuwwisseling af, met de laagste indexwaarde in de gehele tijdreeks in 2012 (figuur 4.1b). Vanaf 2013 wordt weer een toename waargenomen. Dit valt samen met de tuigwisseling in de survey van grote kuil naar verhoogde boomkor. De relatie tussen de dichtheden gevangen met de twee tuigen heeft een grote onzekerheidsmarge (bijlage 5). In hoeverre de toename sinds 2013 dus door de tuigwissel is veroorzaakt is niet te achterhalen. Om deze onzekerheid buiten beschouwing te laten, wordt de bestandsgrootte sinds 2015 alleen vergeleken met de jaren 20132014. De bestandsgrootte sinds 2015 fluctueert sterk en verschilt gemiddeld niet sterk met de twee jaren ervoor (2013-2014); 2015 en 2016 tonen een lagere index-waarde en 2017 een hogere.

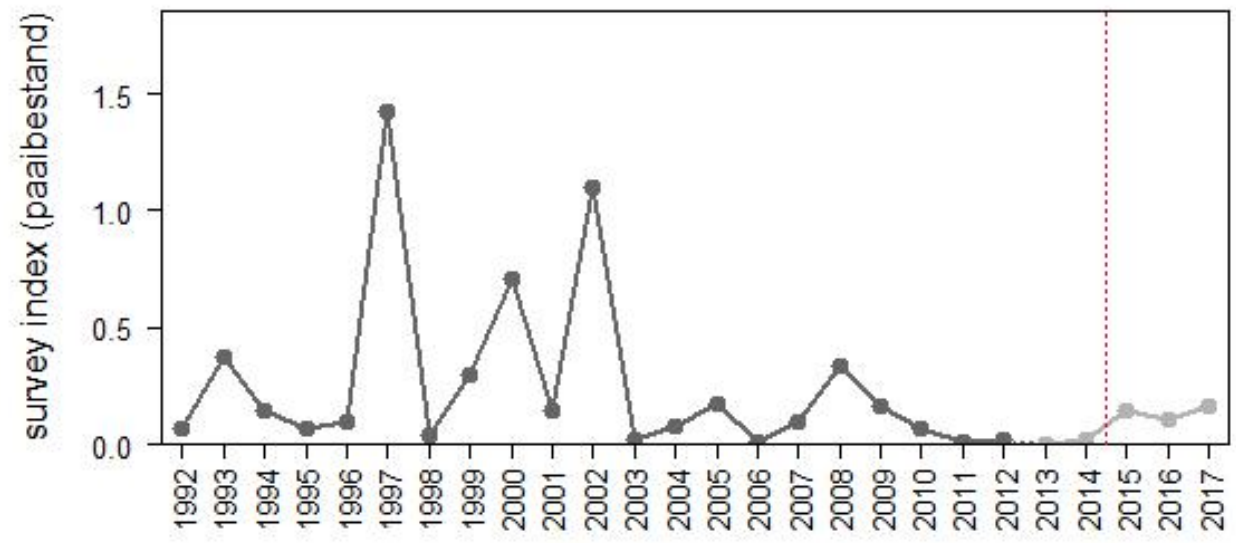

(a)

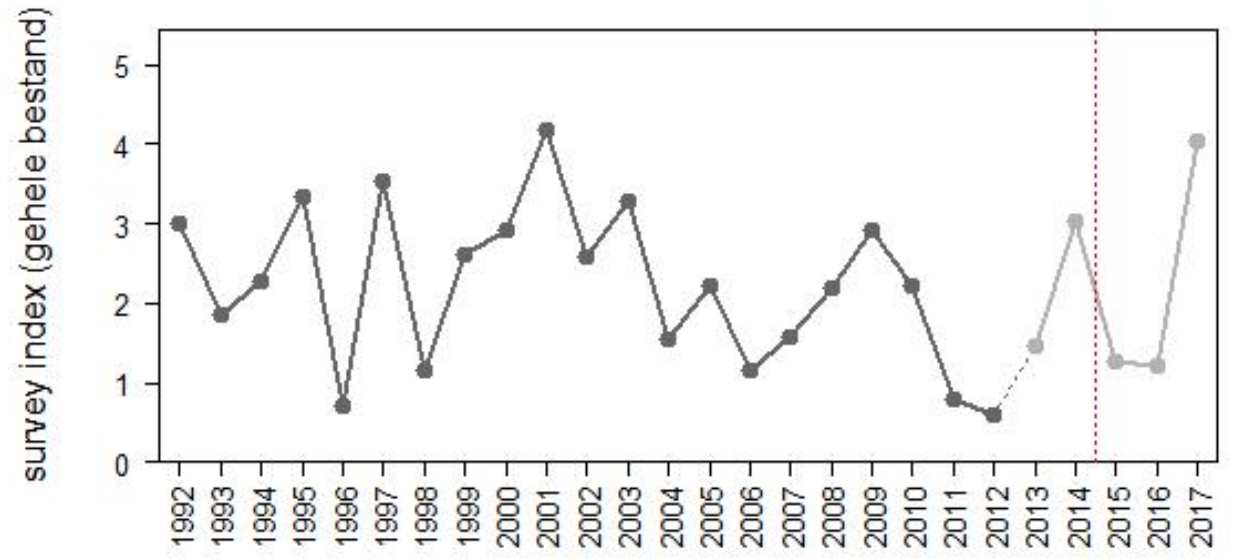

(b)

Figuur 4.1 Biomassa-index voor snoekbaars, boven (a) voor het paaibestand, en beneden (b) voor het gehele bestand. Trend voor het IJ sselmeer en Markermeer gecombineerd. De biomassa-indices betreffen de gemiddelde biomassa-dichtheid (kilogram per hectare) van de openwatersurvey (kuil/boomkor en elektrokor survey in de verhouding 0.7:0.3). De rode lijn is de start van het huidige visserijbeheer. Van 2012 op 2013 is in de kuil/boomkor survey gewisseld van tuig, van grote kuil naar verhoogde boomkor. De achterliggende getallen staan in bijlage 4. 


\subsection{Ontwikkelingen in bestandsopbouw}

Er worden door de tijdserie heen minder grote snoekbaarzen gevangen in de survey (figuur 4.2). De maximale lengte van 0-jarige snoekbaars is grofweg $25 \mathrm{~cm}$, en grotere snoekbaars wordt steeds minder aangetroffen door de tijdreeks heen. Snoekbaarzen groter dan $60 \mathrm{~cm}$ worden vrijwel alleen voor 2003 aangetroffen. Dieptepunt is in 2011, wanneer er maar 1 snoekbaars groter dan $25 \mathrm{~cm}$ werd gevangen. $\mathrm{Na}$ 2011 neemt de hoeveelheid grotere vis weer iets toe.

De index voor de hoeveelheid 0-jarigen fluctueert heel sterk en vertoont geen trend door de tijdreeks heen (figuur 4.3). In 2017 zijn veel 0-jarigen gevangen, de hoogste waarde in de tijdsserie. De index voor de bestandsomvang van 1-jarigen varieert sterk door de tijdreeks heen tot aan 2009, met hoge pieken, die daarna niet meer voorkomen. De jaren 2010-2014 zijn de slechtste jaren van de tijdreeks, maar sinds 2015 ligt de index-waarde weer hoger. De index-waarde voor de hoeveelheid 2-jarigen neemt ook door de tijdreeks heen sterk af, met meerdere pieken tot aan 2008-2009 maar zeer lage waardes sinds 2010.

Vanaf 2015 ligt de index weer iets hoger, in vergelijking met 2010-2014, zoals ook bij de 1-jarigen. De index voor de 3-jarige en oudere vis is in de hele tijdsserie laag, omdat er erg weinig grote vis wordt gevangen. Tot en met 2002 zijn er nog uitschieters omhoog, maar in 2012-2015 werd helemaal geen vis ouder dan 2 jaar gevangen. Van 2015 tot 2017 wordt er weer wat oude vis gevangen. Samengevat lijkt de bestandsomvang van snoekbaars ouder dan 0 jaar een dieptepunt te bereiken in 2010-2014 maar is deze iets verbeterd sinds 2015. Er wordt echter erg weinig grote snoekbaars gevangen in de survey en de onzekerheid van deze indices is groot.

Wat betreft de relatieve biomassaverdeling over de leeftijden (figuur 4.4): Het biomassa-aandeel snoekbaars ouder dan 1 jaar is vrijwel verdwenen in 2012-2014 maar na 2014 lijkt het aandeel 2/3-jarige vis weer iets hoger te liggen.

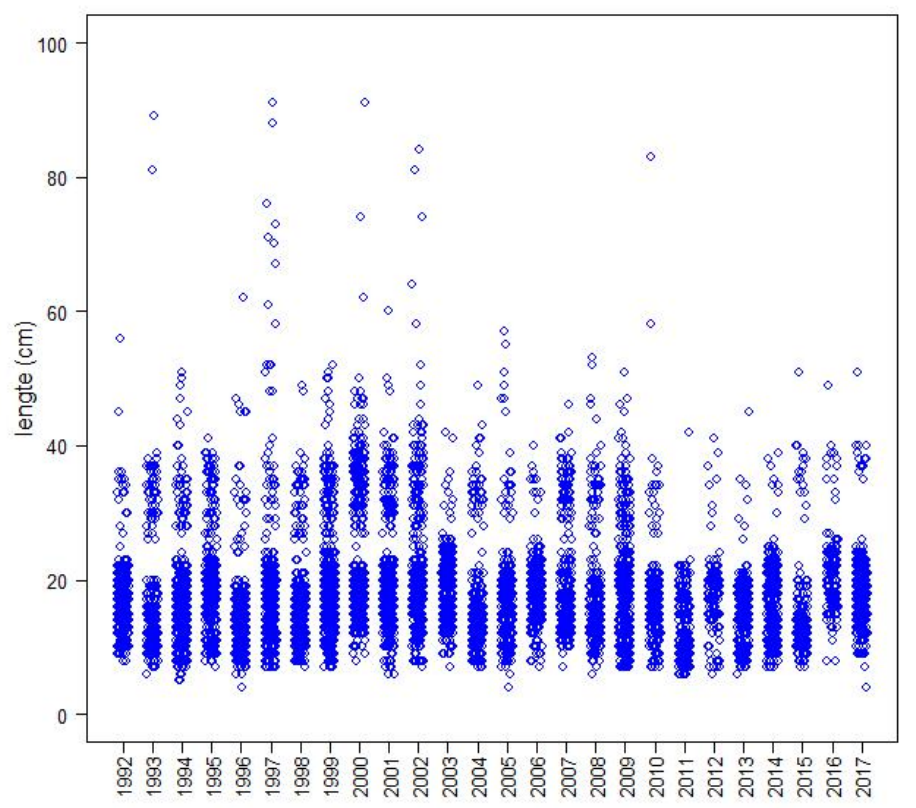

Figuur 4.2 Plot van de lengtes van alle snoekbaarzen (blauwe cirkels) gevangen in de openwatersurvey met kuil/ boomkor/ elektrokor door de jaren heen. Eén blauwe cirkel kan meerdere vissen representeren. 

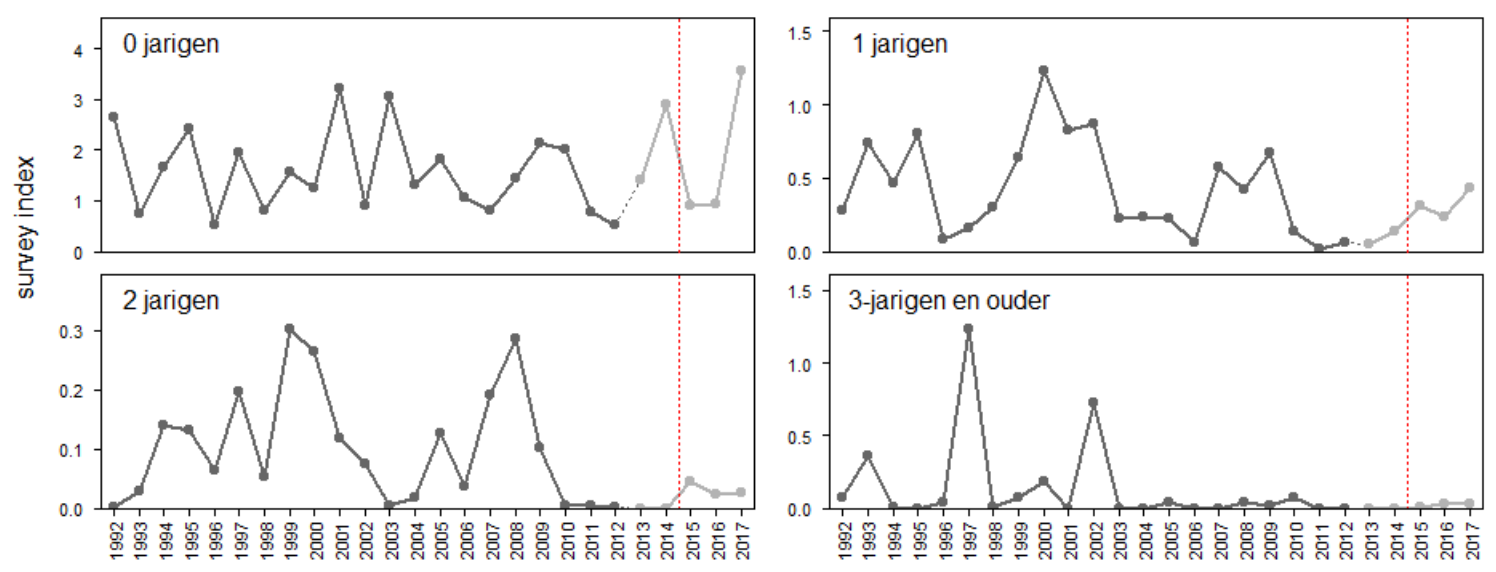

Figuur 4.3 Biomassa-index voor snoekbaars, opgesplitst in leeftijden. Trend voor het IJ sselmeer en Markermeer gecombineerd. De biomassa-index betreft de gemiddelde biomassadichtheid ( kg per hectare) van de openwatersurvey (kuil/boomkor en elektrokor survey in de verhouding 0.7:0.3). De rode lijn is de start van het visserijbeheer. Van 2012 op 2013 is in de kuil/boomkor survey gewisseld van tuig, van grote kuil naar verhoogde boomkor.

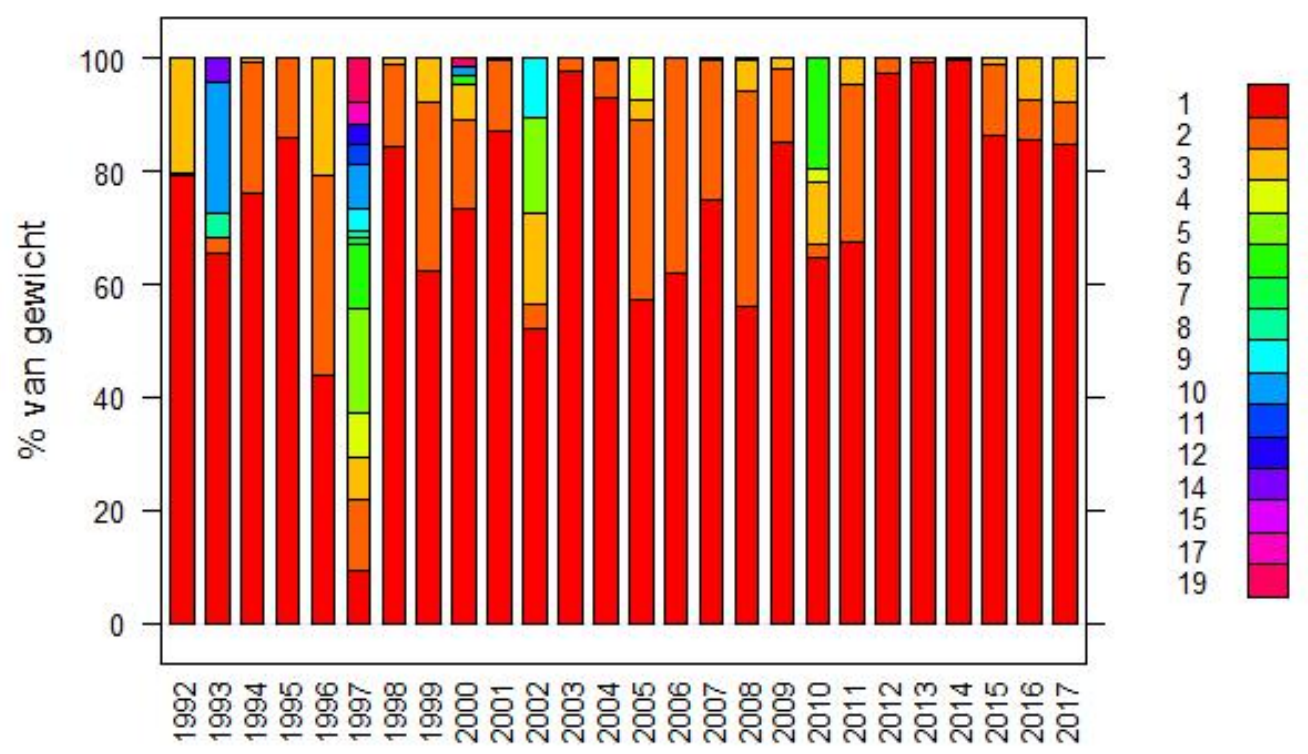

Figuur 4.4 Leeftijdsopbouw van snoekbaars (zonder de 0 -jarige) gevangen in de openwatersurvey met de kuil/ boomkor en de elektrokor door de jaren heen. Het percentage van het gewicht per leeftijdsklasse. Van 2012 op 2013 is gewisseld van tuig, van grote kuil naar verhoogde boomkor.

\subsection{Vangstopbouw}

\subsubsection{Staandwant 101}

De lengte-opbouw van de vangsten van commerciële staandwantnetten met $101 \mathrm{~mm}$ zoals bemonsterd in de marktbemonstering in september-december toont dat er veel ondermaatse snoekbaars wordt gevangen (figuur 4.5): in 2016 is $19 \%$ van het aantal gevangen baars ondermaats en in 2017 bijna de helft; 48\%. In de openwatermonitoring is een piek in hoeveelheid 0-jaar snoekbaars te zien in 2017; wellicht wordt veel ondermaatse snoekbaars in de visserij gevangen in jaren van sterke recruitment. In 2016 worden met name snoekbaarzen van 2-3 jaar oud gevangen, maar in 2017 worden ook 0- en 1-jarigen veel gevangen, met meer 0-jarige dan 3-jarige snoekbaars in de vangst. 


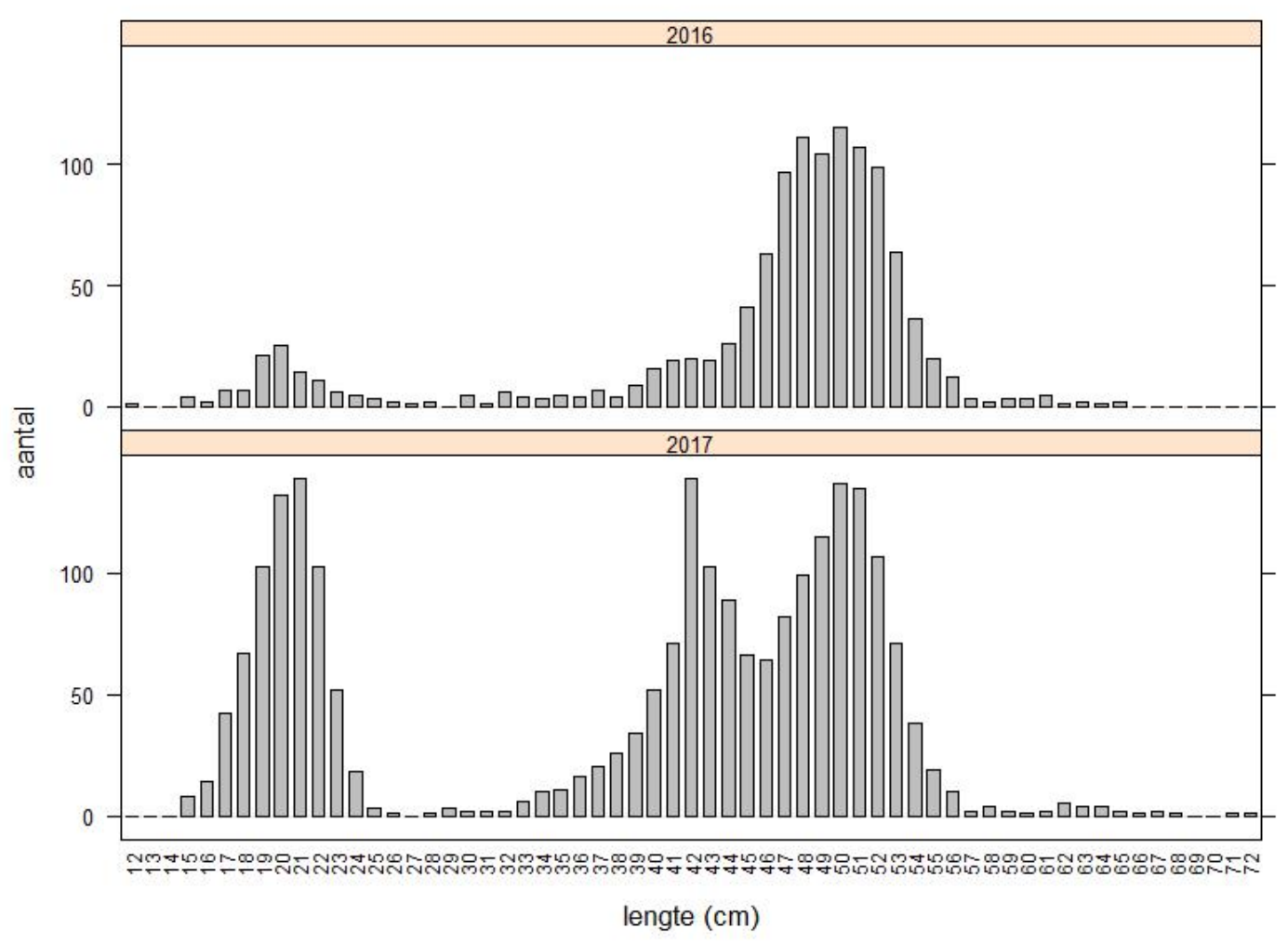

Figuur 4.5 Lengteopbouw van de commerciële snoekbaarsvangsten met staandwantnetten $101 \mathrm{~mm}$, bemonsterd in de marktbemonstering in september-december van 2016 en 2017. Snoekbaars mag worden aangeland vanaf $42 \mathrm{~cm}$.

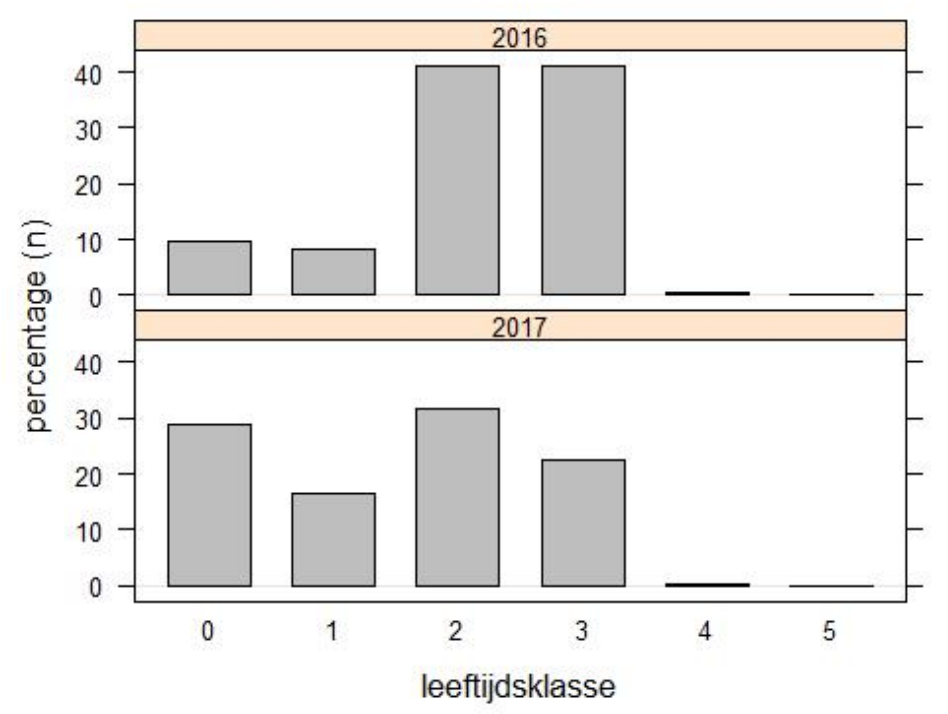

Figuur 4.6 Geschatte leeftijdsopbouw van de commerciële baarsvangsten met staandwantnetten $101 \mathrm{~mm}$, bemonsterd in de marktbemonstering in september-december van 2016 en 2017. De y-as geeft het geschatte percentage van het totaal aantal vissen weer.

\subsubsection{Staandwant 130-190 en zegenvisserij}

Een eerste indruk, op basis van twee vistrips in 2017, over staandwantvisserij met grotere mazen ( 130 en $190 \mathrm{~mm}$ ) is dat in deze visserij de leeftijdsopbouw van gevangen snoekbaars sterk kan variëren. Wanneer er met warrelnetten (130 mm en ladders) werd gevist werden vrijwel alleen maar 0 -jarige snoekbaarzen gevangen (van de in totaal 33 snoekbaarzen), en in de gecombineerde reis 
( 130 en $190 \mathrm{~mm}$ ) hoofdzakelijk snoekbaarzen van 2 jaar en ouder (van de in totaal 31 snoekbaarzen). Er is geen snoekbaars in de zegentrip gevangen.

\subsection{Discussie}

De index voor de totale bestandsomvang vertoont sinds de eeuwwisseling een afname, tot aan het dieptepunt in 2012. Na 2012 is de index weer hoger, maar mogelijk heeft de tuigwissel in de survey in 2013 hier een rol gespeeld. De hoeveelheid paairijpe snoekbaars gevangen in de survey is in de hele tijdreeks laag. Echter, binnen de gemiddeld lage index-waardes in de tijdreeks zijn meerdere relatief sterke jaren te zien tot en met 2002, maar daarna niet meer. Het dieptepunt qua paaibestandsomvang ligt tussen 2011-2014, waarna de index weer iets hoger ligt. Opgesplitst in leeftijden is in alle snoekbaars ouder dan 0 jaar een afname over de tijdreeks te zien met het dieptepunt rond 2012. Alleen de 0-jarigen fluctueren zonder duidelijke trend. 2017 was een goed jaar voor 0 -jarigen, met de hoogste waarde sinds het begin van de tijdreeks.

De situatie vanaf 2015, na de veranderingen in het visserijbeheer, lijkt enigszins verbetering te tonen in vergelijking met 2013 en 2014: na vier jaar van zeer lage paaibiomassa, is vanaf 2015 de paaibiomassa-index weer iets hoger. Er wordt echter heel erg weinig grote snoekbaars gevangen in de survey en de onzekerheid om deze index heen is groot. De index van het totale bestand lijkt vanaf 2015 niet erg verschillend in vergelijking met 2013 en 2014. Dit komt met name doordat er geen trend is in 0 -jarige snoekbaars. 


\section{$5 \quad$ Blankvoorn}

\section{$5.1 \quad$ Ontwikkelingen in bestandsgrootte}

De index voor het paaibestand (figuur 5.1a) neemt sinds het begin van de tijdreeks vrij consistent en sterk af, met zeer lage waardes vanaf 2011 en het dieptepunt in 2016. In 2017 is echter een sterke toename te zien, met de hoogste waarde sinds 2007.

De survey index voor het gehele bestand neemt ook door de hele tijdreeks vrij consistent en sterk af, met de laagste waardes tussen 2011-2016. Ook hierbij is een opleving in 2017 te zien.

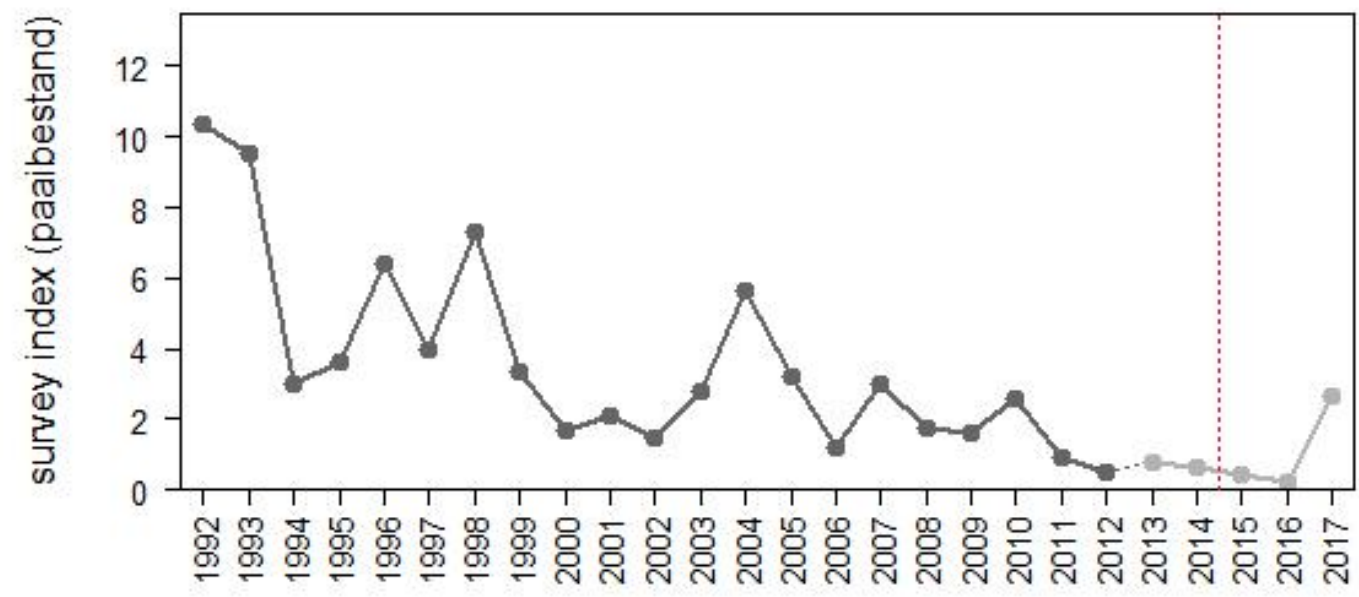

(a)

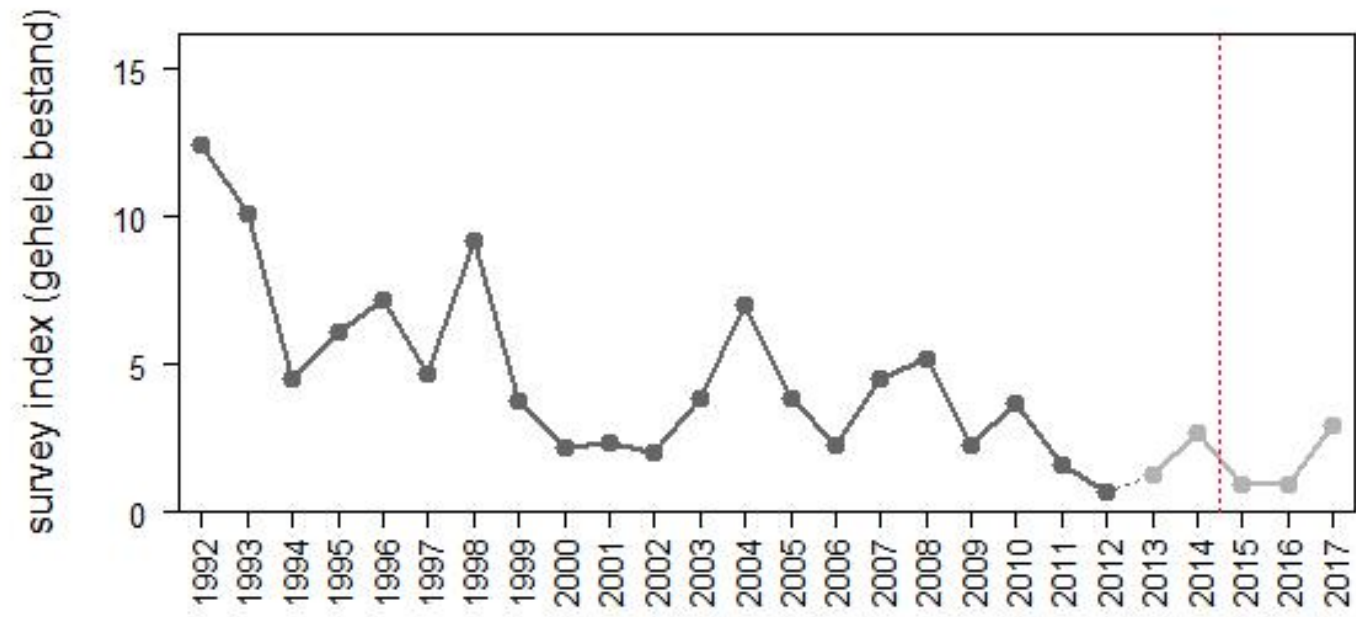

(b)

Figuur 5.1 Biomassa-index voor blankvoorn, boven (a) voor het paaibestand, en beneden (b) voor het gehele bestand. Trend voor het IJ sselmeer en Markermeer gecombineerd. De biomassa-indices betreffen de gemiddelde biomassa-dichtheid (kilogram per hectare) van de openwatersurvey (kuil/boomkor en elektrokor survey in de verhouding 0.7:0.3). De rode lijn is de start van het visserijbeheer. Van 2012 op 2013 is in de kuil/boomkor survey gewisseld van tuig, van grote kuil naar verhoogde boomkor. De achterliggende getallen staan in bijlage 4 


\subsection{Ontwikkelingen in bestandsopbouw}

Er worden door de tijdserie heen steeds minder grote blankvoorns gevangen in de survey (figuur 5.2), met 2016 als dieptepunt. Echter, in 2017 wordt relatief veel grote blankvoorn gevangen, gelijk aan de betere jaren van de tijdreeks. In 2017 is daarentegen de 0 -jarige index erg laag.

De survey-index voor de hoeveelheid 0-jarigen fluctueert sterk en vertoont geen duidelijke trend door de tijdreeks heen (figuur 5.3). Vanaf 2015 neemt de hoeveelheid recruiten wel elk jaar af en recruitment in 2017 is het slechtste jaar na 2000. Het aantal 1-jarigen vertoont een aantal pieken in 2004, 2007 en 2008. De andere jaren fluctueert de index op een lager niveau, zonder duidelijke trend. 2012-2016 waren hierbij wel allemaal slechte jaren, met een dieptepunt in 2015, maar vanaf 2016 lijkt dit zich weer licht te verbeteren. Het aantal 2-jarige blankvoorn neemt door de tijdreeks heen consistent af. Dieptepunt qua index-waardes loopt vanaf 2011 tot en met 2016. In 2017 is er meer gevangen dan de jaren ervoor. De meest duidelijke afname in omvang is te zien in de hoeveelheid 3-jarige en oudere blankvoorn. Deze neemt geleidelijk maar sterk af vanaf het begin van de tijdreeks tot aan 2016, met ook weer een toename in 2017.

In de relatieve biomassaverdeling over de leeftijden ( 1 jaar en ouder, figuur 5.4 ) is te zien dat het aandeel blankvoorn ouder dan 1 jaar (alle kleuren behalve rood) is afgenomen door de tijdreeks heen. Verder is er geen duidelijke trend waar te nemen in de leeftijdsopbouw.

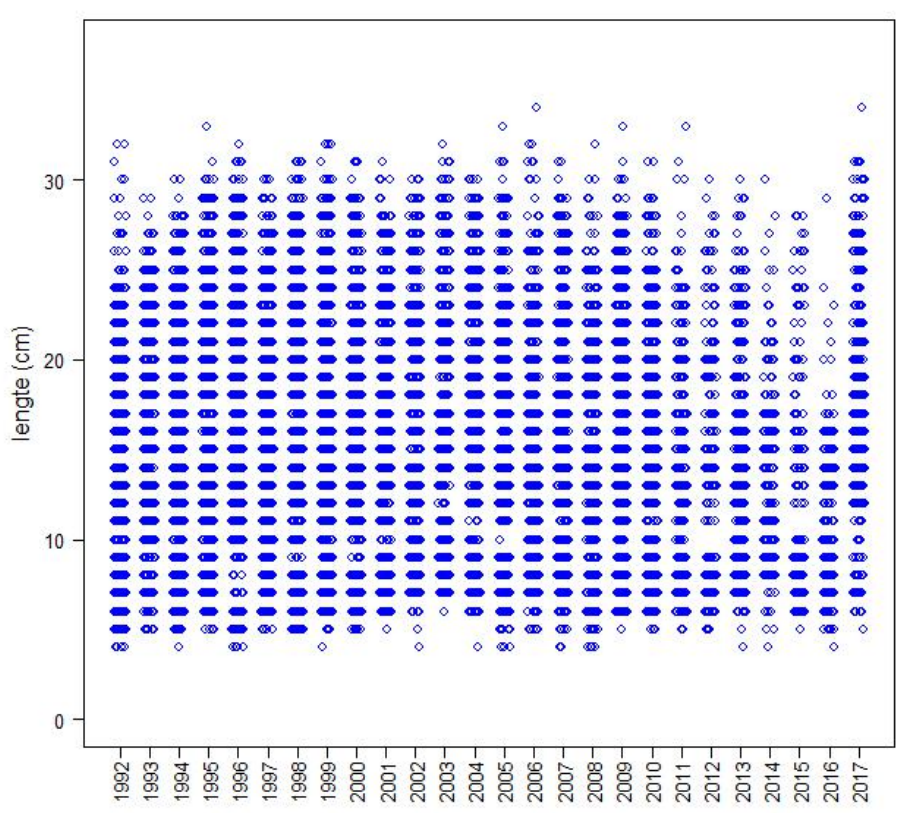

Figuur 5.2 Plot van de lengtes van alle blankvoorn (blauwe cirkels) gevangen in de openwatersurvey met kuil/ boomkor/ elektrokor door de jaren heen. Eén blauwe cirkel kan meerdere vissen representeren. 

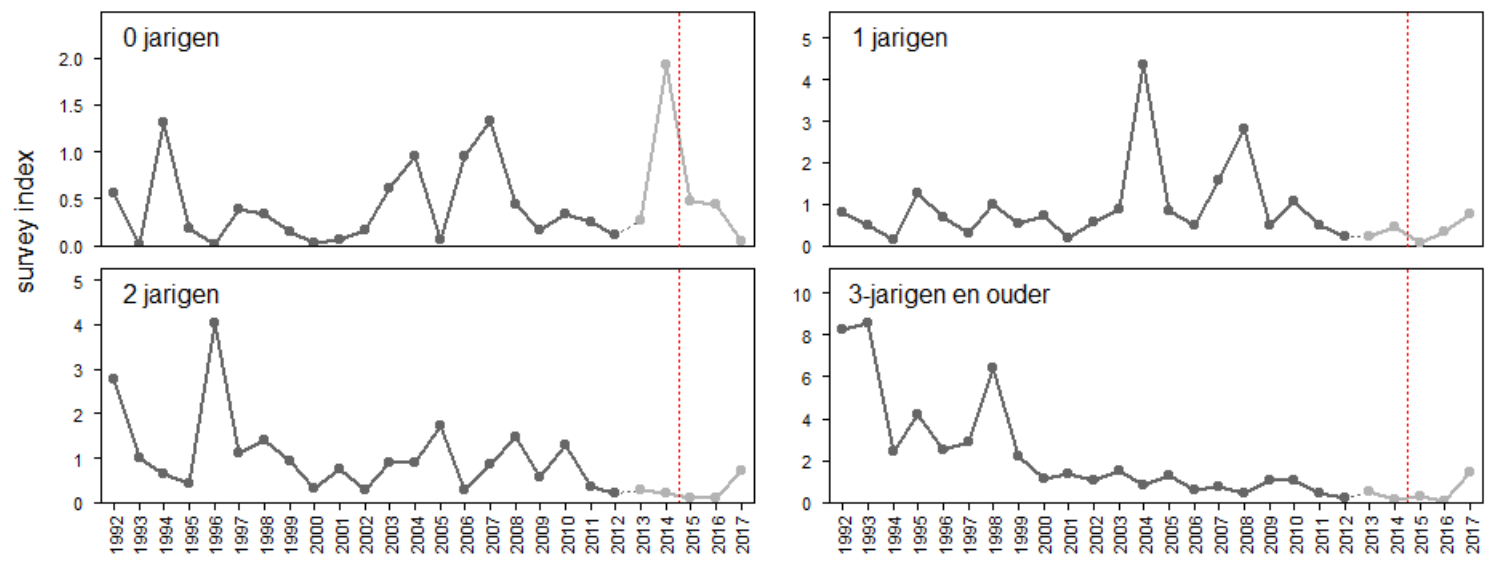

Figuur 5.3 Biomassa-index voor blankvoorn, opgesplitst in leeftijden. Trend voor het IJ sselmeer en Markermeer gecombineerd. De biomassa-index betreft de gemiddelde biomassadichtheid ( kg per hectare) van de openwatersurvey (kuil/boomkor en elektrokor survey in de verhouding 0.7:0.3). De rode lijn is de start van het visserijbeheer. Van 2012 op 2013 is in de kuil/boomkor survey gewisseld van tuig, van grote kuil naar verhoogde boomkor.

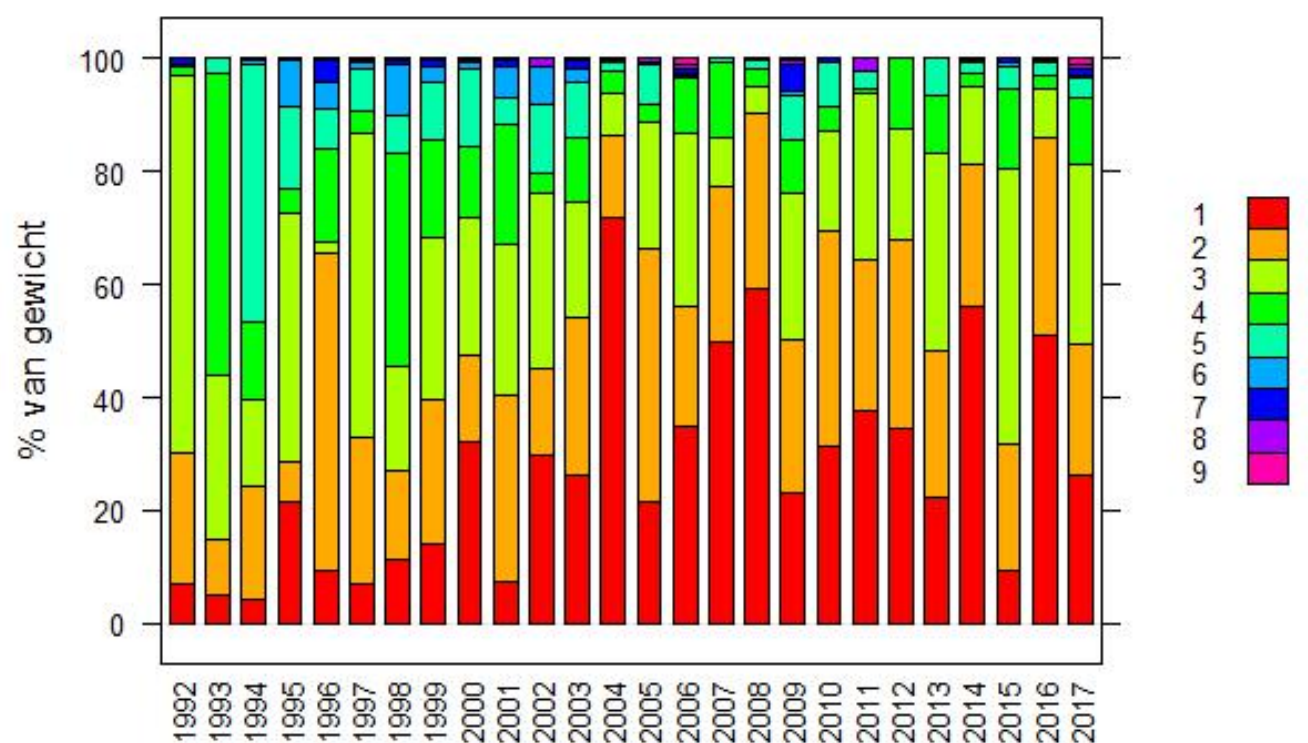

Figuur 5.4 Leeftijdsopbouw van blankvoorn (zonder de 0 -jarige) gevangen in de openwatersurvey met de kuil/ boomkor en de elektrokor door de jaren heen. Het percentage van het gewicht per leeftijdsklasse. Van 2012 op 2013 is gewisseld van tuig, van grote kuil naar verhoogde boomkor.

\subsection{Vangstopbouw}

\subsubsection{Staandwant 101}

De lengteverdeling van blankvoorn van de vangsten van commerciële staandwantnetten met $101 \mathrm{~mm}$ (marktbemonstering in september-december) is vrij smal: er wordt vrijwel uitsluitend blankvoorn van 27-33 cm gevangen (figuur 5.5). De vangsten bestaan vooral uit blankvoorn van 3 jaar en ouder (figuur 5.6). Dit is ook de leeftijdsgroep die het hardst achteruit is gegaan qua bestandsomvang. Vrijwel alle blankvoorn van deze leeftijden zal wel al gepaaid hebben (bijlage 2).

Blankvoorn wordt veel gevangen in deze visserij: over alle bemonsterde 101-visreizen was blankvoorn in 2016 de meest gevangen soort en in 2017 na snoekbaars de meest gevangen soort. 


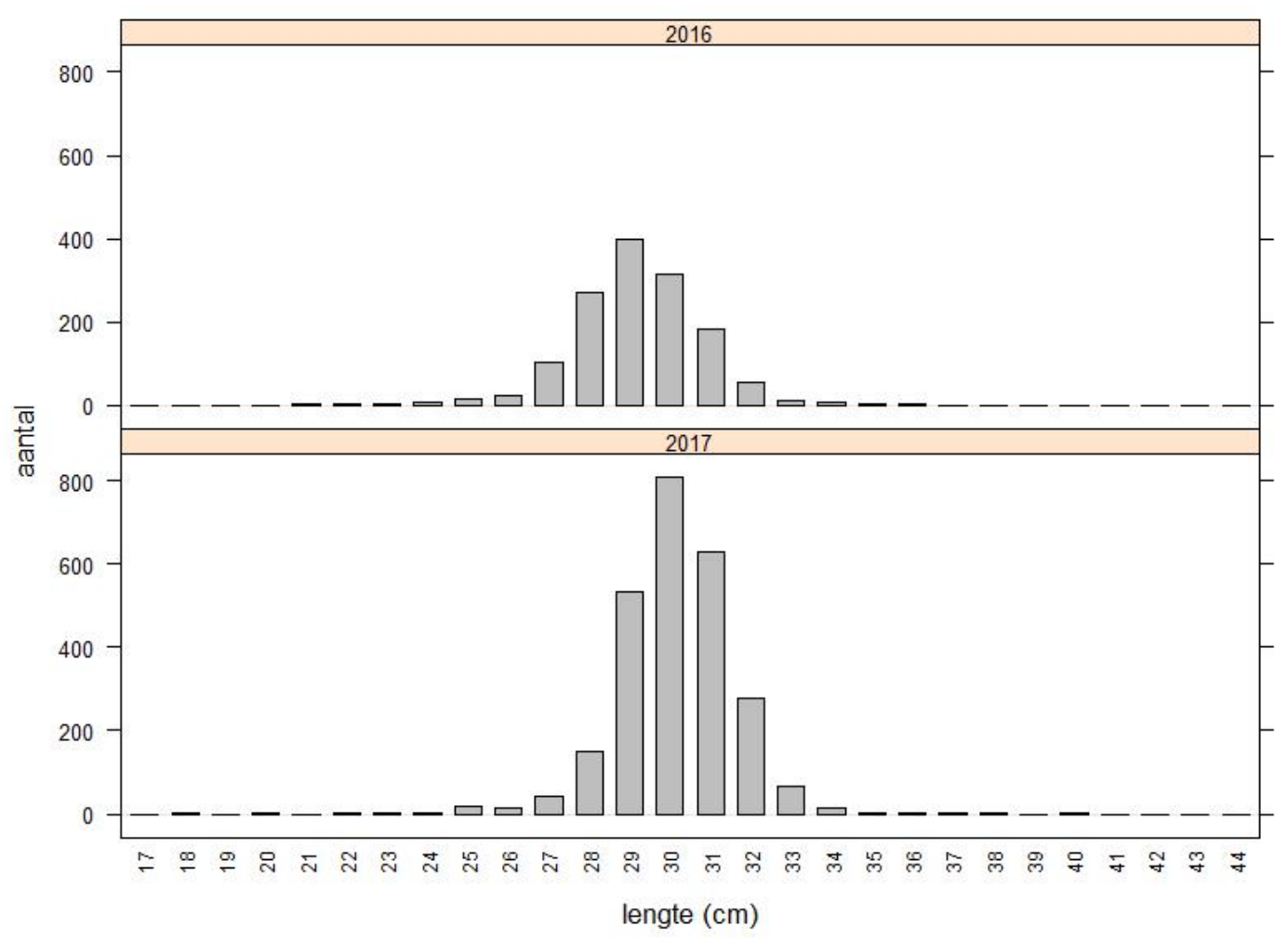

Figuur 5.5 Lengteopbouw van de commerciële snoekbaarsvangsten met staandwantnetten $101 \mathrm{~mm}$, bemonsterd in de marktbemonstering in september-december van 2016 en 2017.

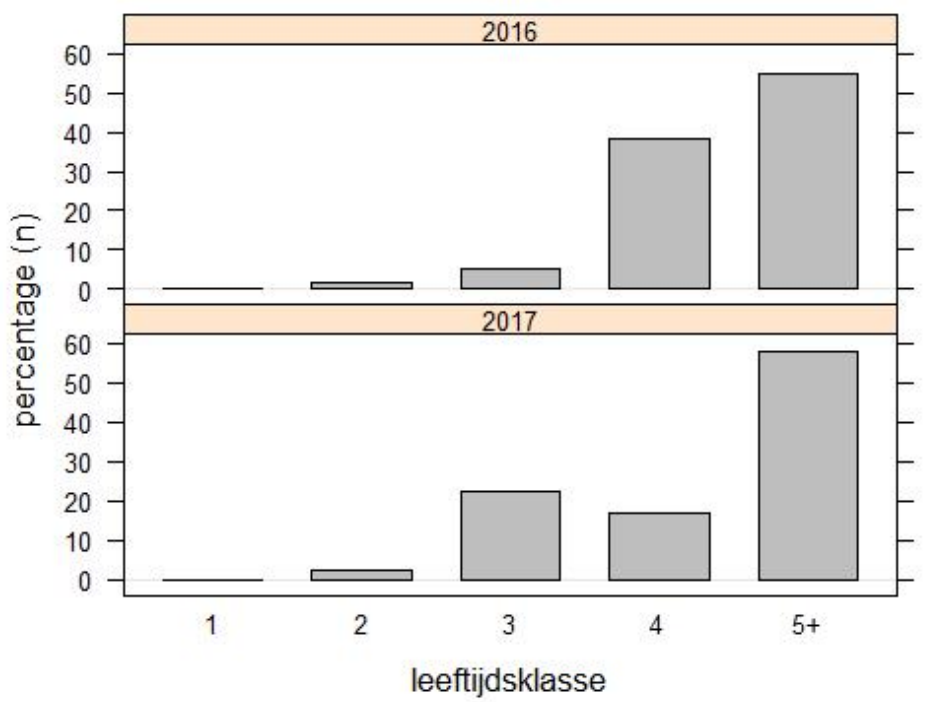

Figuur 5.6 Geschatte leeftijdsopbouw van de commerciële blankvoornvangsten met staandwantnetten $101 \mathrm{~mm}$, bemonsterd in de marktbemonstering in september-december van 2016 en 2017. De $y$-as geeft het geschatte percentage van het totaal aantal vissen weer.

\subsubsection{Staandwant 130-190 en zegenvisserij}

In de twee visreizen met grotere maaswijdtes is maar 1 blankvoorn gevangen, en in de zegentrip geen. 


\subsection{Discussie}

De omvang van het totale blankvoornbestand neemt consistent af door de tijdreeks heen, met de laagste waardes tussen 2011-2016. De hoeveelheid paairijpe blankvoorn neemt ook consistent af door de tijdreeks, met het dieptepunt in 2016. In 2017 is een toename te zien in totale biomassa en paaibiomassa. Dit wordt veroorzaakt door een toename in de hoeveelheid vis ouder dan 0 jaar; de hoeveelheid 0-jarige blankvoorn zit juist op een dieptepunt in 2017. Qua bestandsopbouw is te zien dat de afname in het bestand het eerst waarneembaar is in de oudere jaarklassen. Er lijkt geen trend in recruitment (0-jarige), alleen is wel sprake van zeer slechte recruitment in 2017.

De situatie vanaf 2015, na de veranderingen in het visserijbeheer, lijkt geen verbetering te tonen. De bestandsomvang (geheel en paai) vertoont een afnemende trend die doorzet tot aan 2016. Alleen in 2017 lijkt de bestandomvang weer iets toe te nemen, in vergelijking met de jaren 20112016. Dit betreft een toename van alle leeftijden ouder dan 0 jaar. Of hier sprake is van een robuuste bestandsverbetering is met 1 jaar niet te zeggen. Gezien de zeer lage recruitment in 2017, is het aannemelijk dat dit geen stabiele verbetering in het bestand weergeeft. 


\section{Brasem}

\subsection{Ontwikkelingen in bestandsgrootte}

De index voor het paaibestand (figuur 6.1a) neemt door de tijdreeks heen sterk en consistent af. Sinds 2007 wordt vrijwel geen paairijpe brasem gevangen, met als dieptepunt 2014-2016 toen er helemaal geen volwassen brasem werd gevangen.

De survey index voor het gehele bestand neemt ook door de hele tijdreeks sterk en vrij consistent af, met de laagste index-waarde in de gehele tijdreeks in 2015 (figuur 6.1b). In 2016-2017 is de indexwaarde iets hoger dan 2015, maar nog steeds heel erg laag.

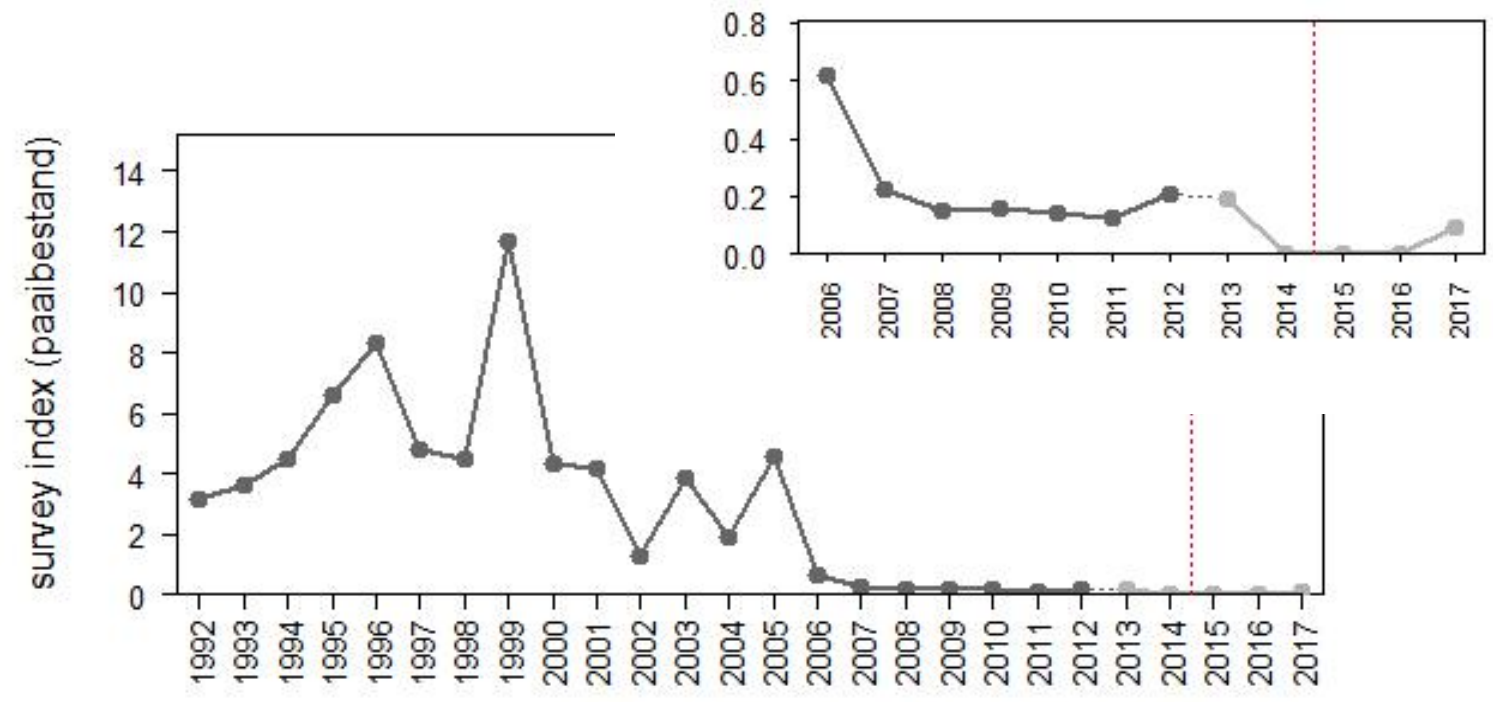

(a)

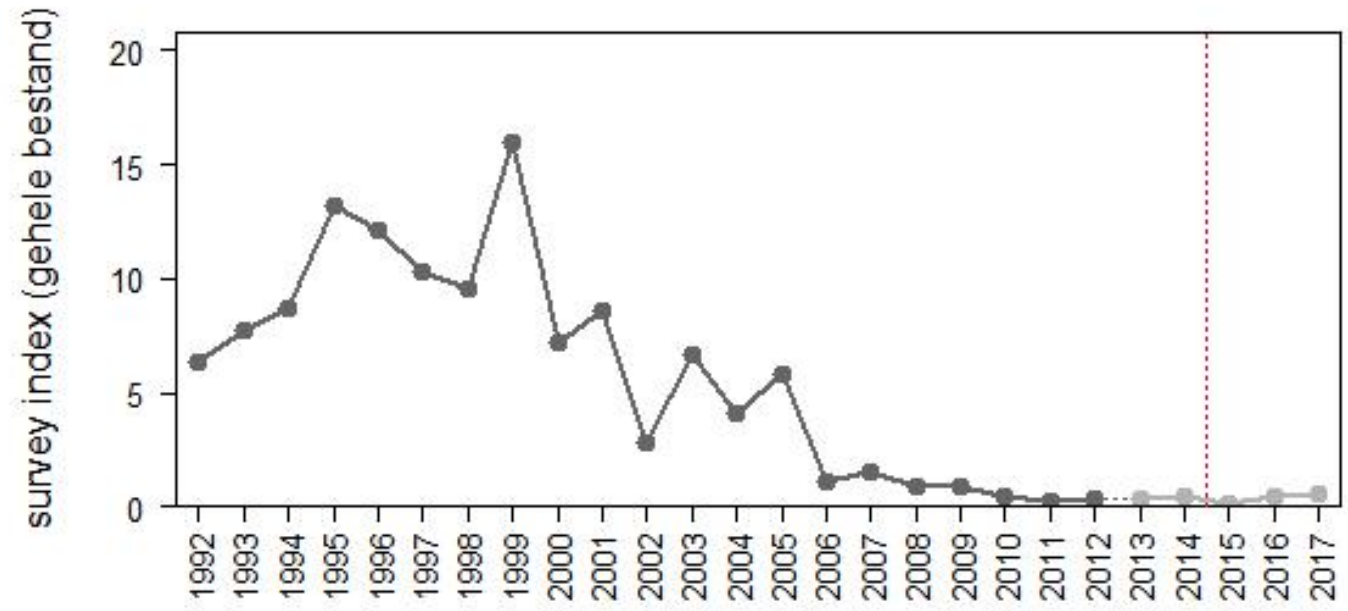

(b)

Figuur 6.1 Biomassa-index voor brasem, boven (a) voor het paaibestand (met een vergroting voor 2006-2017), en beneden (b) voor het gehele bestand. Trend voor het IJ sselmeer en Markermeer gecombineerd. De biomassa-indices betreffen de gemiddelde biomassadichtheid (kilogram per hectare) van de openwatersurvey (kuil/boomkor en elektrokor survey in de verhouding 0.7:0.3). De rode lijn is de start van het visserijbeheer. Van 2012 op 2013 is in de kuil/boomkor survey gewisseld van tuig, van grote kuil naar verhoogde boomkor. De achterliggende getallen staan in bijlage 4 . 


\subsection{Ontwikkelingen in bestandsopbouw}

Er worden door de tijdserie heen steeds minder grote brasems gevangen in de survey (figuur 6.2), tot aan het dieptepunt in 2014-2015. In 2017 worden meer middelgrote brasems gevangen dan de drie jaar ervoor. Echter, de echt grote brasem (groter dan $\sim 45 \mathrm{~cm}$ ), zoals die voor 2007 regelmatig werden gevangen, ontbreken vooralsnog in de vangsten.

De survey-index van 0-jarige brasem liet tot aan de eeuwwisseling nog sterke jaren zien, maar daarna niet meer (figuur 6.3). Sinds de eeuwwisseling is verder geen duidelijke trend te zien in de recruitment. Het dieptepunt van de 0 -jarig index ligt in 2015, met zeer weinig nieuwe recruiten. In 2016 en 2017 is de recruitment index weer relatief goed. Het aantal 1-jarigen nam door de tijdreeks heen af, met zeer slechte index-waarden vanaf 2008. De laagste punten waren in 2011/2012 en in 2015. In 2016 en 2017 is een lichte verbetering te zien in de hoeveelheid 1-jarigen ten opzichte van 2015, maar deze waardes zijn niet beter dan de jaren voor 2015. Het aantal 2-jarigen is ook door de tijdreeks heen sterk afgenomen, met hele lage waarden vanaf 2009 tot aan 2017. Het aantal 3-jarige en oudere vis is ook door de tijdreeks heen sterk afgenomen, met hele lage waarden vanaf 2006.

In de relatieve biomassaverdeling over de leeftijden (1-jarig en oud, figuur 6.4) is te zien dat tot aan 2006 een grote diversiteit aan leeftijden werd gevangen. Daarna wordt jaarlijks zeer weinig oudere vis gevangen.

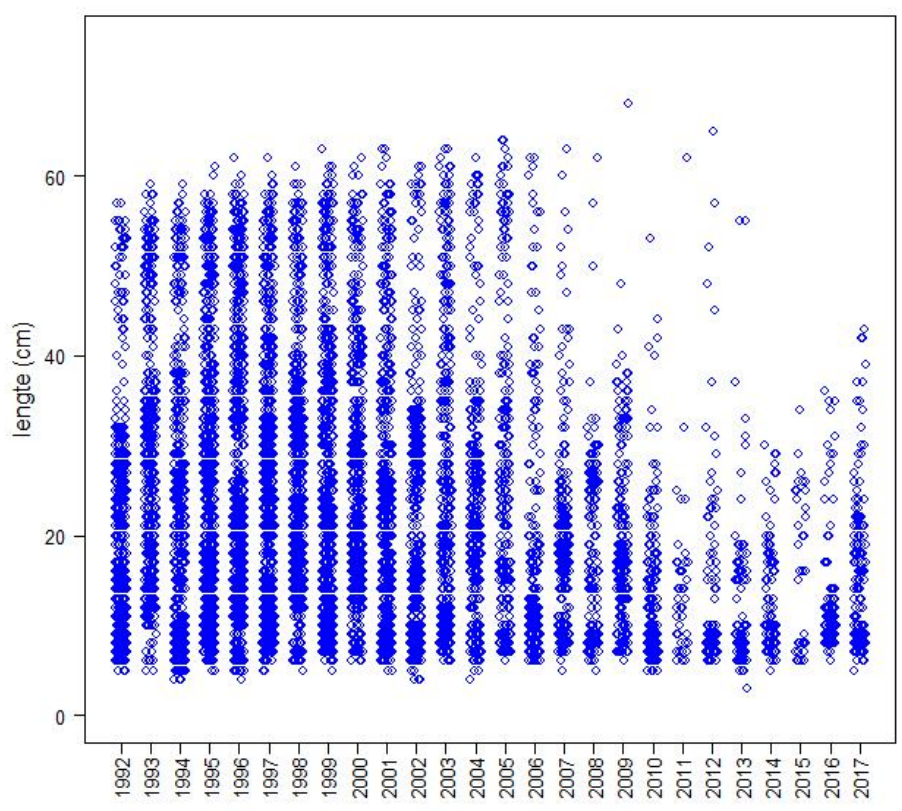

Figuur 6.2 Plot van de lengtes van alle brasem (blauwe cirkels) gevangen in de openwatersurvey met kuil/ boomkor/ elektrokor door de jaren heen. Eén blauwe cirkel kan meerdere vissen representeren. 

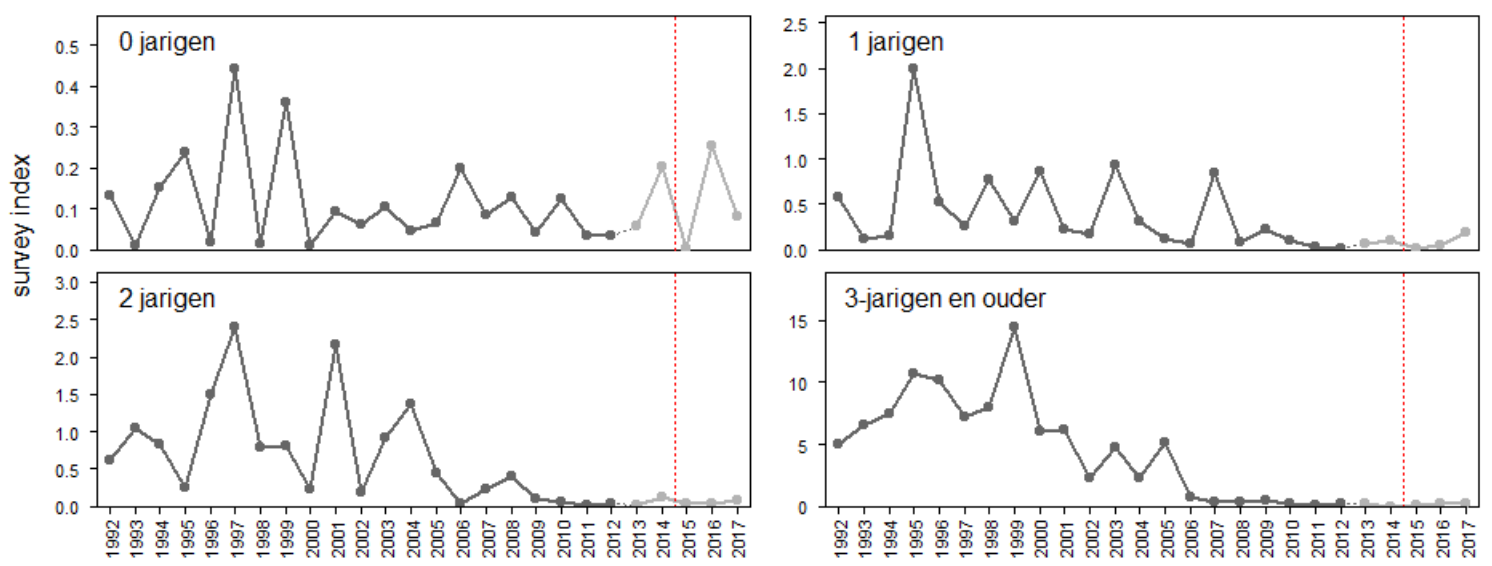

Figuur 6.3 Biomassa-index voor brasem, opgesplitst in leeftijden. Trend voor het IJ sselmeer en Markermeer gecombineerd. De biomassa-index betreft de gemiddelde biomassa-dichtheid ( $\mathrm{kg}$ per hectare) van de openwatersurvey (kuil/boomkor en elektrokor survey in de verhouding 0.7:0.3). De rode lijn is de start van het visserijbeheer. Van 2012 op 2013 is in de kuil/boomkor survey gewisseld van tuig, van grote kuil naar verhoogde boomkor.
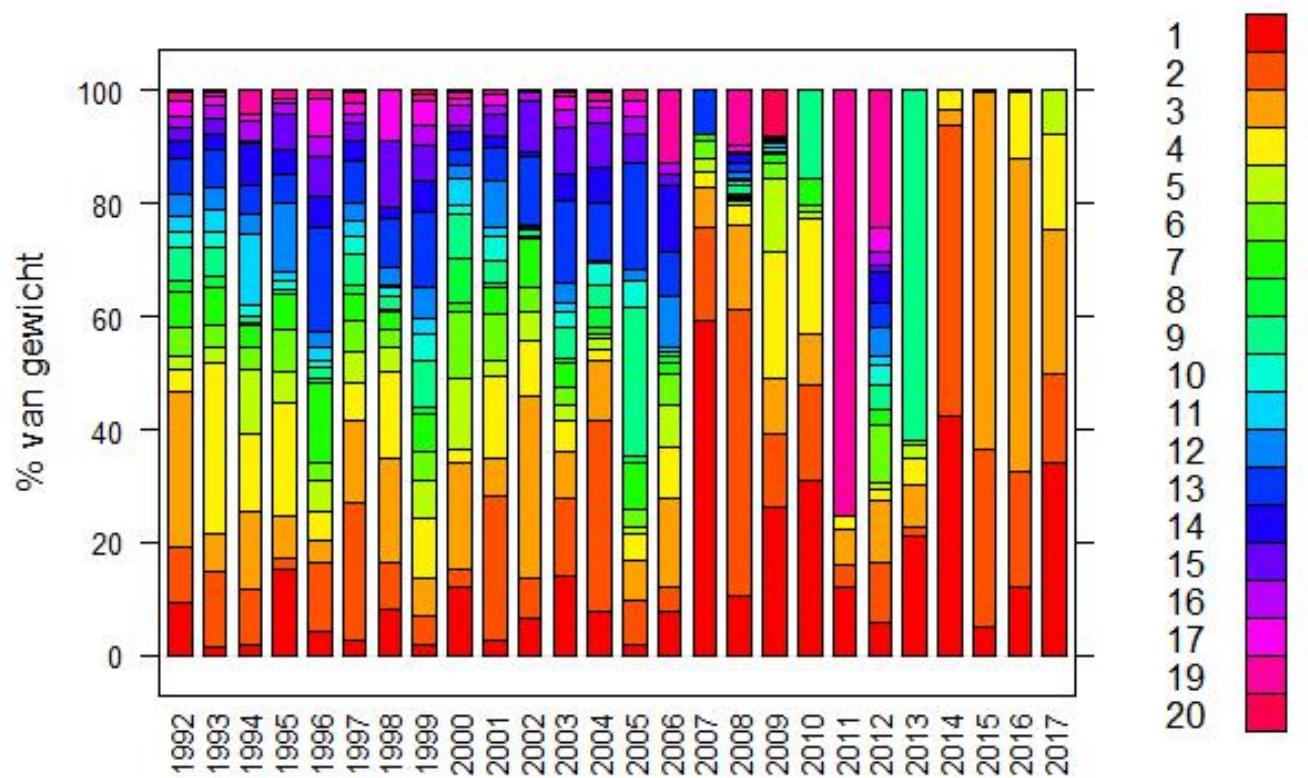

Figuur 6.4 Leeftijdsopbouw van brasem (zonder de 0 -jarige) gevangen in de openwatersurvey met de kuil/ boomkor en de elektrokor door de jaren heen. Het percentage van het gewicht per leeftijdsklasse. Van 2012 op 2013 is gewisseld van tuig, van grote kuil naar verhoogde boomkor.

\subsection{Vangstopbouw}

\subsubsection{Staandwant $101 \mathrm{~mm}$}

De commerciële staandwantvisserij met $101 \mathrm{~mm}$ zoals bemonsterd in de marktbemonstering in september-december vangt voornamelijk brasem van $\sim 26-45 \mathrm{~cm}$. Dit betreft hoofdzakelijk brasem van 2-3 jaar oud. Dit is vooral juveniele brasem: pas op 5-jarige leeftijd is $50 \%$ van de brasem adult (bijlage 2). Brasem wordt dus in de staandwantvisserij voornamelijk gevangen voordat deze heeft kunnen paaien. 


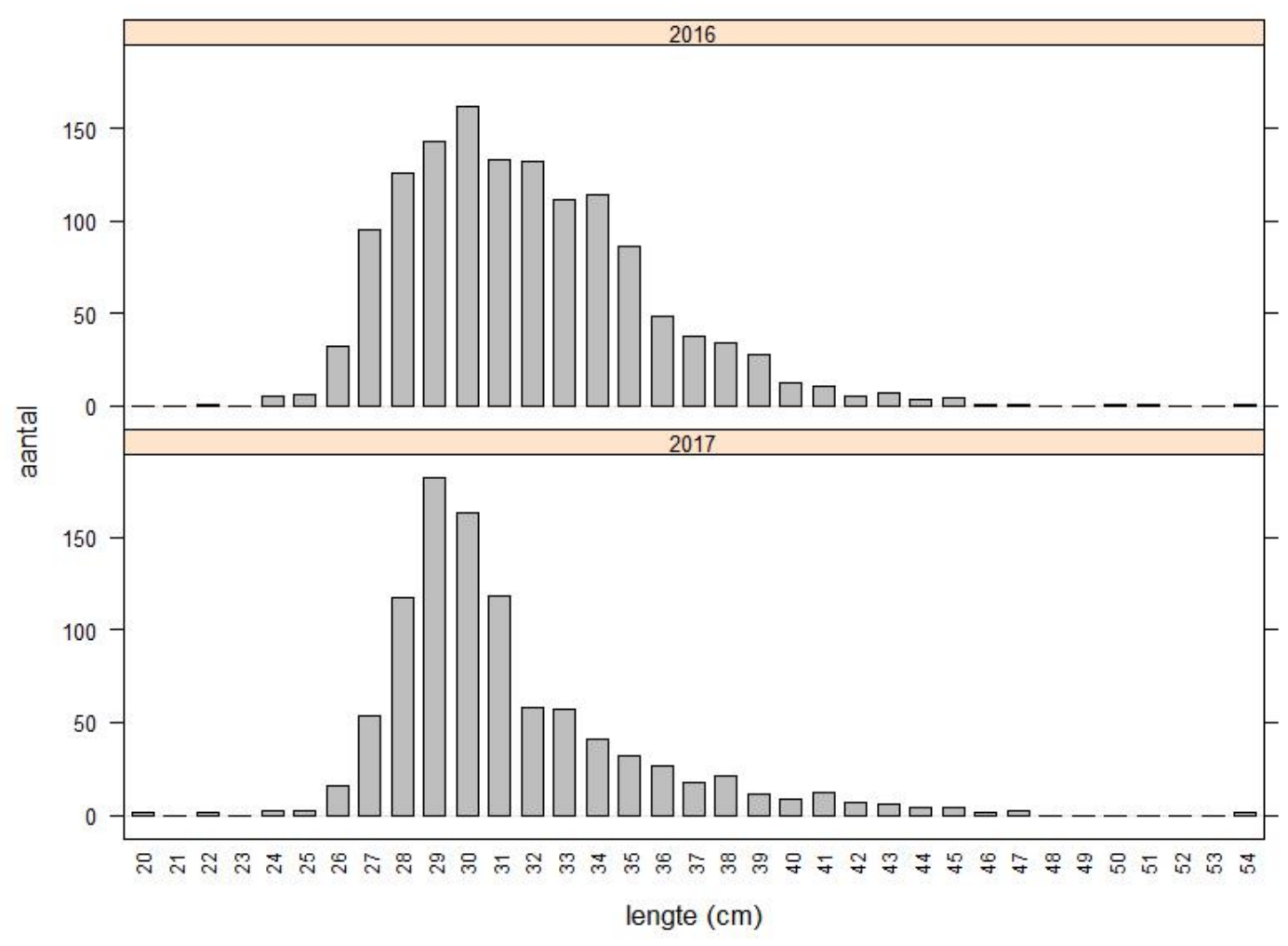

Figuur 6.5 Lengteopbouw van de commerciële snoekbaarsvangsten met staandwantnetten $101 \mathrm{~mm}$, bemonsterd in de marktbemonstering in september-december van 2016 en 2017.

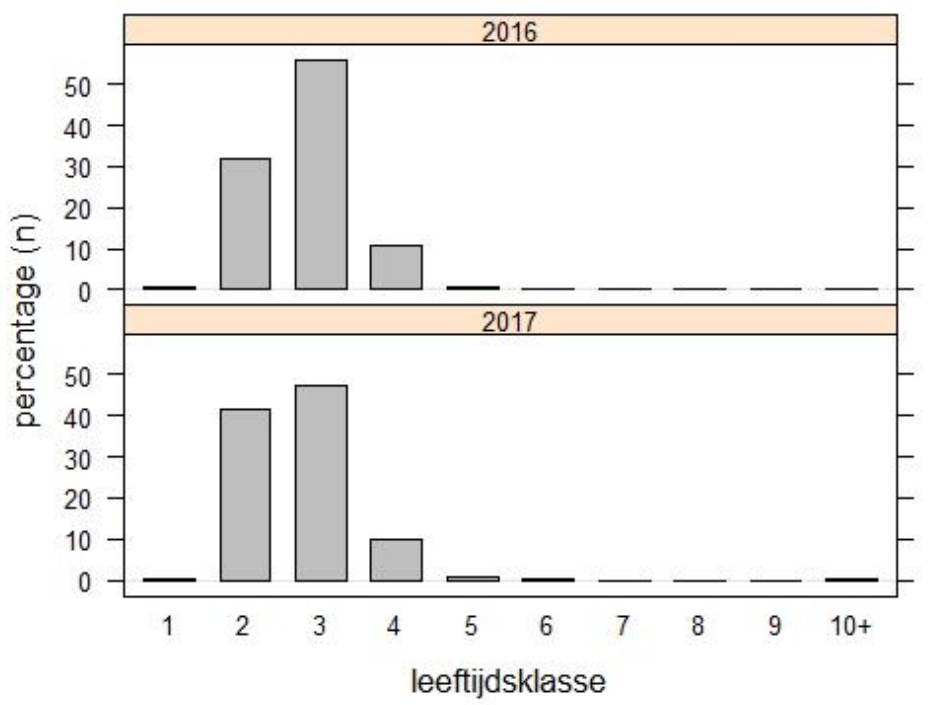

Figuur 6.6 Geschatte leeftijdsopbouw van de commerciële baarsvangsten met staandwantnetten $101 \mathrm{~mm}$, bemonsterd in de marktbemonstering in september-december van 2016 en 2017. De $y$-as geeft het geschatte percentage van het totaal aantal vissen weer.

\subsubsection{Staandwant 130-190 en zegenvisserij}

In de marktbemonstering van de grotere maaswijdtes in 2017 is alleen brasem gevangen in de reis met 130-190 mm (180 brasems). Hierbij zijn oudere brasems gevangen dan in de $101 \mathrm{~mm}$, namelijk vooral brasem van 4 jaar en ouder. De vistrip met zegenvisserij ving vrijwel uitsluitend brasem (95\%). Hierbij is een veel breder spectrum aan lengtes gevangen dan bij een staandwantreis; brasem van 16 tot en met $64 \mathrm{~cm}$ is gevangen, zonder een duidelijke focus qua lengte. 


\subsection{Discussie}

De index voor de gehele bestandsgrootte is sterk en consistent afgenomen in de tijdreeks. Ook de hoeveelheid paairijpe brasem in de survey neemt consistent en sterk af door de tijdreeks. Het dieptepunt wat betreft beide survey-indices ligt in 2014-2015. Sinds 2007 wordt vrijwel geen paairijpe brasem aangetroffen, terwijl deze in de vroegere jaren in grote aantallen werd gevangen. Opgesplitst in leeftijdsklassen zijn sterke afnames in de omvang van alle leeftijden vanaf 1 jaar te zien. Tot aan 2006 werd een grote diversiteit aan leeftijden gevangen, maar daarna niet meer.

De situatie vanaf 2015 , na de veranderingen in het visserijbeheer, toont geen consistente verbetering in bestandsomvang ten opzichte van de jaren ervoor. Wel wordt wat meer 1-jarige vis gevangen in 2016/2017 dan in 2015 maar deze waardes zijn niet hoger dan de jaren voor 2015.

Samengevat is de bestandsopbouw van brasem sterk verslechterd, met zeer slechte index waardes voor alle leeftijden vis vanaf 2007. 2015 was een dieptepunt qua bestandsomvang en opbouw, met in de jaren erna geen verbetering ten opzichte van de jaren voor 2015. 


\section{$7 \quad$ Conclusies}

\subsection{Ontwikkelingen vanaf 1992}

Over de periode 1992-2017 vertonen alle vier bestanden negatieve ontwikkelingen. Voor alle bestanden lijkt ook te gelden dat bij oudere leeftijdsgroepen de afname in hoeveelheid vis eerder en/of sterker is geweest. Alle vier bestanden vertonen een dieptepunt qua bestandomvang en hoeveelheid grote vis in de periode vanaf 2012.

- Baars: het paaibestand van baars neemt door de tijdreeks heen af, met de laagste indexwaardes in 2015. Ook de omvang van gehele bestand is tussen 2004-2013 relatief laag.

- Snoekbaars: Het totale bestand van snoekbaars neemt door de tijdreeks af, met de laagste index-waarde in 2012. Het paaibestand laat geen positieve signalen in de survey-indices zien, waarbij het paaibestand tussen 2011-2014 relatief laag lijkt te zijn. Wel is de recruitment in 2017 relatief hoog.

- Blankvoorn: De index-waarde voor het paaibestand van blankvoorn neemt door de tijdreeks heen consistent af, met de laagste index-waardes in 2016. Het dieptepunt van de bestandomvang van de 1- en 2- jarige en de 3-jarige en oudere blankvoorn ligt in alle gevallen na 2011. De laagste index-waarde wat betreft 0-jarigen is aangetroffen in 2017. Daar staat tegenover dat de andere leeftijden juist lijken toegenomen qua bestandsomvang in 2017.

- Brasem: Het paaibestand en het totale bestand van brasem nemen zeer sterk en consistent af door de tijdreeks heen, met het dieptepunt qua index-waardes rond 2014-2016. Het dieptepunt wat betreft recruitment ligt in 2016.

Gezien de relatief slechte situatie vanaf 2012 in alle vier bestanden, zou herstel dus gericht moeten zijn op een verbetering naar een situatie voorafgaand aan deze periode.

Er is ook onderzocht of er signalen in de surveygegevens zijn voor recruitment impairment (bijlage 6): een situatie waarbij de aanwezige adulten niet de maximale hoeveelheid aanwas kunnen produceren. Dit zou betekenen dat herstel van het bestand belemmerd zou kunnen worden, door een tekort aan adulten. Voor snoekbaars, brasem en blankvoorn zijn de surveygegevens niet goed genoeg om uitspraken hierover te doen; het verband tussen de paaibiomassa en de aantallen juvenielen is niet duidelijk. Voor baars lijkt dit verband wel aanwezig; er zijn dus signalen dat een risico op recruitment impairment bestaat.

\subsection{Ontwikkelingen vanaf 2015}

Alle vier bestanden laten in 2015-2017 geen consistente achteruitgang zien ten opzichte van de jaren ervoor (2012-2014). Ten opzichte van deze (slechte) jaren gaat het in met name 2016-2017 in sommige opzichten iets beter. Zo is de hoeveelheid oudere baars (2-jarig) iets hoger dan in de jaren ervoor. De bestandsomvang van blankvoorn gaat achteruit tot en met 2016, maar de index-waardes in 2017 zijn weer relatief positief. Brasem vertoont geen positieve ontwikkelingen. Van brasem kan ook verwacht worden dat herstel veel langer duurt, gezien de late leeftijd waarop deze soort volwassen wordt: pas op 5-jarige leeftijd is $50 \%$ van de brasem paairijp (bijlage 2 ). De surveyvangsten van oudere snoekbaars (1-2 jaar) zijn consistent iets hoger in 2015-2017 dan in de jaren voor 2015. Echter, de onzekerheid om deze survey-indices voor snoekbaars heen is erg groot. Andere positieve signalen zijn dat de recruitment van baars, snoekbaars en brasem relatief hoog is in 2016 en/of 2017. Daarentegen is de recruitment van blankvoorn juist lager in 2015-2017, met de laagste recruitment sinds 2000 in 2017. Hierbij moet wel in acht worden genomen dat variatie in recruitment een normaal verschijnsel is en vaak afhangt van temperatuurontwikkelingen in voorjaar en zomer. Hierdoor kan het sterk aan toeval onderhevig zijn. Effecten van veranderd beheer op veranderingen in recruitment kunnen daarom niet per jaar beoordeeld worden, alleen over een tijdsbestek van een aantal jaren. 
De doelstelling van het beheer zoals ingezet in 2014 was 'geen verdere achteruitgang'. Deze doelstelling lijkt in lijn met de situatie in het veld. Voor de huidige beheersdoelstelling ('herstel', zie hoofdstuk 1.1) zijn geen consistente signalen aangetroffen in de surveygegevens. Er lijken echter wel een paar kleine positieve ontwikkelingen te zijn in met name 2016 en 2017.

\subsection{Discussiepunten}

\subsubsection{Survey versus commerciële aanlandingen}

Van beroepsvissers komen signalen dat de trends zoals aangetroffen in de survey niet stroken met de trends die zij in hun aanlandingen zien. Daarom worden in bijlage 7 de trends in de survey vergeleken met die in de aanlandingen. Als de paai-indices naast de PO-aanlandingen worden gelegd, zijn voor snoekbaars, baars en blankvoorn grofweg dezelfde ontwikkelingen door de tijd te zien. Met name snoekbaars laat vrijwel identieke trends in de survey en in de aanlandingen zien. Voor blankvoorn en baars zijn de overeenkomsten minder precies, maar alsnog zijn vrijwel dezelfde patronen van afname te zien. Alleen de surveytrend van brasem komt niet goed overeen met de aanlandingen, maar dit kan verklaard worden doordat de onzekerheden in de PO-

aanlandingsgegevens voor brasem groot zijn.

Er zijn meerdere onzekerheden in zowel de PO-aanlandingsregistratie (bijlage 7) als de survey-indices (hoofdstuk 2.1). Wat betreft de survey-indices zijn met name de vangsten van oudere snoekbaars zeer laag, wat de gegenereerde indices voor oudere snoekbaars onzeker maakt. Daarnaast geldt in principe, dat ook wanneer er wel zeer betrouwbare survey- en aanlandingsgegevens zouden zijn, de trends alsnog niet overeen hoeven te komen. Immers, vissers zijn zeer flexibel in hoeveel en waar ze vissen. Zo kan een visser bij een lage bestandsgrootte zijn inspanning erop verhogen, zodat de vangsten gelijk blijven - of verlagen en overstappen op een andere type visserij. Daarnaast kan het veranderde visserijbeheer in 2014 een invloed hebben gehad op de hoeveelheid inspanning, en dus op de hoeveelheid aanlandingen. Ook de visprijs zal grote invloed op de hoeveelheid inspanning per bestand hebben, en dus op de hoeveelheid aanlandingen. Zo kan bijvoorbeeld een visser bij een goede garnalenprijs zich vooral richten op de garnalenvisserij in de Waddenzee, en niet op staandwantvisserij in de meren. Daarnaast kan bij bestanden die in scholen leven en in voorspelbare habitats, zeer gericht gevist worden op de marktwaardige vis; hierbij kan dus in weerwil van afnemende bestandsgroottes de vangst gelijk blijven.

Hoewel dus (a) zowel de survey-indices als de PO-aanlandingen onzekerheden bevatten, en (b) trends in aanlandingen niet perse representatief zijn voor de trends in bestandgrootte, zijn voor snoekbaars, baars en blankvoorn dezelfde trends door de tijd te zien in de paai-index en in de POaanlandingen. Dit versterkt vooral het vertrouwen in de voorzichtige signalen zoals aangetroffen in de survey, dat de hoeveelheid oudere snoekbaars sinds 2015 iets lijkt toe te nemen.

\subsubsection{Oorzaak-gevolg}

In welke mate het aangepaste beheer sinds visseizoen 2014/2015 verantwoordelijk is voor de situatie in de meren sinds 2015 kan niet onderzocht worden. Door een gebrek aan visserijgegevens, is onbekend hoeveel de totale visserij-inspanning is afgenomen door het verscherpte visserijbeheer. Aangezien informatie over de inspanning pas sinds eind 2016 verzameld wordt in logboeken, is deze vraag ook niet meer te beantwoorden. Ook is onbekend of het beheer geleid heeft tot een afname in visserijsterfte. Om een eerste indruk van de visserijsterfte te krijgen zijn meerdere jaren aan informatie over de vangstopbouw van de visserij nodig. Voor een nauwkeurigere schatting van de visserijsterfte is daarnaast in ieder geval ook 5-7 jaar aan betrouwbare informatie over de hoeveelheid aanlandingen noodzakelijk.

\subsubsection{Visserij-adviezen in de toekomst}

Zoals besproken in hoofdstuk 7.1 en 7.2 hebben alle vier bestanden een dieptepunt qua bestandsomvang vanaf 2012, en zijn er wat signalen voor lichte verbetering in met name 2016-2017. De vangstadviezen zoals gegeven in de afgelopen jaren zijn berekend via ICES-methodiek categorie 
3.2 (Tien et al. 2017). De basis van deze adviezen is de verhouding tussen de bestandstoestand in de laatste drie jaar en in de vijf jaar ervoor. De doelstelling hierbij, is dat de bestanden niet moeten afnemen ten opzichte van de situatie in die vijf voorgaande jaren. Als er volgend jaar een visserijadvies wordt gegeven op basis van deze methodiek, dan wordt in de vangstadviezen dus gestreefd naar een situatie welke een dieptepunt behelst qua bestandsgrootte (namelijk zoals in 2011-2015).

Het ministerie van LNV streeft echter naar herstel van de bestanden (hoofdstuk 1.1). Afgelopen jaar zijn daarom verregaande aanvullende adviezen gegeven. De komende jaren is de intentie om over te stappen op een ICES-methodiek in categorie $3.1^{2}$. In deze categorie is de doelstelling maximale, duurzame vangsten. Deze doelstelling sluit beter aan bij de doelstelling van het ministerie.

\subsubsection{Aanbevolen nader onderzoek}

\section{Meer ecologisch onderzoek}

Behalve de visserijsterfte zijn er meer factoren die een rol spelen in de bestandsontwikkelingen. Natuurlijke sterfte verschilt per jaar, door bijvoorbeeld verschillen in predatiedruk door andere vissoorten of vogels, door kannibalisme of door competitie. Vooral bij 0-jarige vis is de natuurlijke sterfte groot, waarbij veranderingen of natuurlijke fluctuaties in abiotische omstandigheden tot grote verschillen tussen de jaren kan leiden. De sterke opkomst van grondels in de meren zou tot meer predatie op schubvis geleid kunnen hebben - of juist tot een nieuwe voedselbron voor de schubvis. Ook sterfte van discards kan van grote invloed zijn. Verder kan de draagkracht van het systeem veranderd zijn, bijvoorbeeld door veranderingen in de nutriëntenhuishouding. Zoals in hoofdstuk 2 uiteengezet, is de periode met de grootste verandering in de nutriëntenhuishouding (de jaren 70 en 80 ) buiten beschouwing gelaten in de analyses. Echter, kleine veranderingen in de nutriëntenhuishouding sindsdien kunnen ook nog effecten op de bestanden hebben. Tevens kunnen historisch grote veranderingen in de nutriëntenhuishouding nu nog doorwerken op het ecosysteem. Over al deze potentiële factoren en hun relatieve invloed is weinig bekend. Onderzoek dat leidt tot een beter begrip van veranderingen in de onderlinge relaties in het ecosysteem is sterk aan te raden.

Als er meer bekend wordt over de ecologische interacties tussen soorten en tussen trofische niveaus, kan deze informatie ook meegenomen worden bij het definiëren van de beleidsdoelstellingen en het genereren van de visserij-adviezen. Een ecosysteembenadering draagt ook bij aan het eerder bereiken van een duurzame visserij op de meren.

\section{Verschil tussen IJ sselmeer en Markermeer}

Het IJ sselmeer en het Markermeer worden gescheiden door de Houtribdijk. Door de (spui)sluizen in de dijk, zijn de meren echter niet volledig gescheiden en is er uitwisseling van vis. Deze dijk zal wel zorgen voor een beperking van deze uitwisseling. Ook verschillen het IJsselmeer en Markermeer in ecologie; het Markermeer is kleiner en ondieper dan het IJ sselmeer en heeft een ander bodemprofiel. Wanneer de uitwisseling van vissen tussen de meren beperkt is, is de verwachting dat de bestandsontwikkelingen niet synchroon lopen bij beide meren. Dit valt ook terug te zien in de indexwaarden, waarbij het IJ sselmeer en het Markermeer niet altijd hetzelfde patroon vertonen. Ook de visserijdruk kan sterk verschillen tussen de meren. Het wordt daarom aanbevolen om de ontwikkelingen in de meren apart te volgen, en eventueel in het beheer rekening te houden met het verschil in dynamica tussen de twee meren.

\subsubsection{Enquête Beroepsvissers.}

In het najaar van 2016 heeft WMR het initiatief genomen om een enquête te laten uitvoeren onder de beroepsvissers. Doel van deze enquête was om de praktijkkennis van beroepsvissers in het IJ sselmeergebied systematisch te bundelen. De enquête is geïnspireerd op de zogenaamde North Sea Stock Survey (NSSS; Napier, 2014). Op verzoek van het ministerie is deze enquête in december 2017 herhaald. De resultaten van deze enquête zullen apart worden gepubliceerd, hieronder volgen de eerste (voorlopige) resultaten van de vier schubvissoorten.

\footnotetext{
${ }^{2}$ De methodieken in categorie 3.1 zijn nog in ontwikkeling. Ook voor de IJsselmeerbestanden zullen bestaande methodieken nog aangepast en getest moeten worden. Dit zal in 2018 plaatsvinden.
} 
De enquête is naar 56 beroepsvissers verstuurd, . In totaal zijn 25 enquêtes teruggestuurd, waarvan alle 25 bruikbaar zijn voor de analyse. Hiermee is een 'response rate' van $45 \%$ gehaald. Deze response rate is iets lager dan vorig jaar (48\%).

In de enquête is de respondenten gevraagd om een inschatting te maken van de bestandsontwikkelingen, op basis van eigen inzicht, in relatieve veranderingen - aanwezigheid in het jaar 2017 ten opzichte van 2016 - van acht soorten waarop commercieel wordt gevist. In deze sectie geven we de resultaten van de geschatte veranderingen in hoeveelheid marktwaardige en nietmarktwaardige baars, snoekbaars, blankvoorn en brasem. Dit jaar is daarbij aan de vissers gevraagd om, indien ze verschillen waarnamen, hun waarnemingen voor het IJ sselmeer en het Markemeer afzonderlijk in te vullen.

Baars - Een groot deel van de respondenten geeft aan meer of veel meer maatse baars waar te hebben genomen op het IJsselmeer in 2017 ten opzichte van 2016 (78\%), 6\% zag minder maatse baars en volgens $11 \%$ was de hoeveelheid onveranderd. Op het Markermeer zagen $44 \%$ van de respondenten meer maatse baarzen, volgens $31 \%$ was de situatie onveranderd en $25 \%$ gaf aan minder maatse baars te hebben gezien in 2017.

De hoeveelheid ondermaatse baars op het IJ sselmeer was volgens $44 \%$ meer, volgens $11 \%$ veel meer en volgens 44\% onveranderd ten opzichte van 2016. Op het Markermeer is sprake van een wisselend beeld; minder volgens $13 \%$, onveranderd volgens 38\% en meer volgens $50 \%$ ( $31 \%$ meer en $19 \%$ veel meer gezien).

Snoekbaars - De hoeveelheid maatse snoekbaars in 2017 in het IJ sselmeer was volgens iets minder dan de helft van de respondenten onveranderd (45\%). 45\% gaf aan meer maatse snoekbaars te hebben gezien en $10 \%$ zag juist minder maatse snoekbaars op het IJ sselmeer in 2017 . Op het Markermeer gaf $61 \%$ aan evenveel maatse snoekbaars te hebben waargenomen in 2017. Op datzelfde meer zag 28\% meer maatse snoekbaars en 11\% zag minder maatse snoekbaars in 2017.

Niet-marktwaardige hoeveelheid snoekbaars in 2017 in het IJ sselmeer was ook volgens $45 \%$ van de respondenten onveranderd. Een even groot deel gaf aan meer of veel meer ondermaatse snoekbaars te hebben gezien ( $\operatorname{resp} 35 \%$ en $10 \%$ ) en $10 \%$ zag juist minder ondermaatse snoekbaars op het IJ sselmeer in 2017. Op het Markermeer gaf 56\% aan evenveel ondermaatse snoekbaars te hebben waargenomen in 2017. Een deel zag meer of veel meer ondermaatse snoekbaars (resp $28 \%$ en $6 \%$ ) en $11 \%$ zag minder ondermaatse snoekbaars in 2017.

Blankvoorn - De hoeveelheid marktwaardige blankvoorn op het IJsselmeer in 2017 was volgens 39\% van de respondenten onveranderd. De rest zag juist meer tot veel meer marktwaardige blankvoorn (resp 44\% en 11\%), terwijl 6\% veel minder marktwaardige blankvoorn zag. Het beeld op het Markermeer was wisselend; $13 \%$ zag er minder maatse blankvoorn in 2017, volgens $27 \%$ was de situatie onveranderd en de rest zag meer tot veel meer blankvoorn (resp 47\% en 13\%).

De hoeveelheid niet-marktwaardige blankvoorn op het IJsselmeer was volgens $61 \%$ van de respondenten op deze vraag onveranderd. De rest (33\%) gaf aan meer blankvoorn te zien in 2017, of juist veel minder (6\%). Op het Markermeer zag 7\% minder niet markt-waardige blankvoorn en was volgens de rest van de respondenten de situatie onveranderd $(47 \%)$ of meer $(47 \%)$

Brasem - De hoeveelheid marktwaardige brasem op het IJsselmeer in 2017 was volgens de respondenten gelijk (50\%) of meer (43\%), 7\% geeft aan minder marktwaardige brasem te hebben gezien. Op het markermeer was het beeld grofweg gelijk; $45 \%$ zag er evenveel en volgens $55 \%$ van de respondenten was er in 2017 meer brasem dan in 2016.

Op het IJ sselmeer was het beeld van de niet-marktwaardige brasem als volgt: $8 \%$ zag minder in 2017 dan in 2016, 46\% zag evenveel, eveneens 38\% zag er meer en $8 \%$ zag veel meer. Op het Markermeer zag 56\% van de respondenten evenveel niet-marktwaardige brasem in 2017 ten opzichte van 2016 en 44\% zag er meer.

Samengevat zijn de vissers over het algemeen redelijk positief over de hoeveelheid schubvis in 2017 ten opzichte van 2016. De vissers zijn het meest positief over de toestand van baars in zowel het I) sselmeer als het Markermeer, zowel voor de maatse als de ondermaatse baarzen. Ook de surveyvangsten wat betreft het gehele bestand (figuur 3.1b) en specifiek de maatse baarzen (ongepubliceerde gegevens) laten een toename van 2016 naar 2017 zien. De relatief hoge recruitment 
van snoekbaars die is waargenomen in de survey in 2017 lijkt niet door alle vissers te zijn waargenomen. Wel komt deze in de marktbemonstering naar voren (figuur 4.5). 


\section{$8 \quad$ Kwaliteitsborging}

Wageningen Marine Research beschikt over een ISO 9001:2008 gecertificeerd kwaliteitsmanagementsysteem (certificaatnummer: 187378-2015-AQ-NLD-RvA). Dit certificaat is geldig tot 15 september 2018. De organisatie is gecertificeerd sinds 27 februari 2001. De certificering is uitgevoerd door DNV Certification B.V.

Het chemisch laboratorium te IJ muiden beschikt over een NEN-EN-ISO/IEC 17025:2005 accreditatie voor testlaboratoria met nummer L097. Deze accreditatie is geldig tot 1 april 2021 en is voor het eerst verleend op 27 maart 1997; deze accreditatie is verleend door de Raad voor Accreditatie. Het chemisch laboratorium heeft hierdoor aangetoond in staat te zijn op technisch bekwame wijze valide resultaten te leveren en te werken volgens de ISO17025 norm. De scope (L097) met de geaccrediteerde analysemethoden is te vinden op de website van de Raad voor Accreditatie (www.rva.nl).

Op grond van deze accreditatie is het kwaliteitskenmerk Q toegekend aan de resultaten van die componenten die op de scope staan vermeld, mits aan alle kwaliteitseisen is voldaan.. Het kwaliteitskenmerk Q staat vermeld in de tabellen met de onderzoeksresultaten. Indien het kwaliteitskenmerk $\mathrm{Q}$ niet staat vermeld is de reden hiervan vermeld.

De kwaliteit van de analysemethoden wordt op verschillende manieren gewaarborgd. De juistheid van de analysemethoden wordt regelmatig getoetst door deelname aan ringonderzoeken waaronder die georganiseerd door QUASIMEME. Indien geen ringonderzoek voorhanden is, wordt een tweede lijnscontrole uitgevoerd. Tevens wordt bij iedere meetserie een eerstelijnscontrole uitgevoerd. Naast de lijnscontroles wordende volgende algemene kwaliteitscontroles uitgevoerd:

- Blanco onderzoek.

- Terugvinding (recovery).

- Interne standaard voor borging opwerkmethode.

- Injectie standard.

- Gevoeligheid.

Bovenstaande controles staan beschreven in Wageningen Marine Research werkvoorschrift ISW 2.10.2.105.

Indien gewenst kunnen gegevens met betrekking tot de prestatiekenmerken van de analysemethoden bij het chemisch laboratorium worden opgevraagd.

Indien sprake is van onbeheerste kwaliteit worden passende maatregelen genomen. 


\section{Literatuur}

- Beverton, R. J. H., Holt, S. J., (1992) Recruitment and egg-production, in: On the Dynamics of

- Exploited Fish Populations (Chapman \& Hall, London, 1993) pp. 44-67.

- ICES, 2017. Advice Technical Guidelines. 12.4.3.1 ICES fisheries management reference points for category 1 and 2 stocks. DOI : 10.17895/ices.pub. 3036

- Napier 2014. Fishers' North Sea Stock Survey 2014. NAFC Marine Centre. 98pp.

- Noordhuis, Los, Groot en Platteeuw, 2014. Wetenschappelijk eindadvies ANTIjsselmeergebied. Vijf jaar studie naar kansen voor het ecosysteem van het IJ sselmeer, Markermeer en Ijmeer met het oog op de Nature-2000 doelen. Deltares rapport

- Ricker W.E., (1954). Journal of the Fisheries Research Board of Canada, 11(5): 559-623, https: //doi.org/10.1139/f54-039

- Schram et al. (in prep). De volledigheid van de aanlandings- en inspanningsregistraties voor de schubvisvisserij op het IJ sselmeer en Markermeer. WMR-rapport in prep.

- Tien, van der Hammen en van Hal, 2015. Vangstadviezen voor snoekbaars, baars, blankvoorn en brasem in het IJ sselmeer en Markermeer. IMARES rapport C045/15.

- Tien en van der Hammen, 2015. Langetermijn opties voor het visserij-advies over schubvis op het IJ sselmeer en Markermeer. I MARES rapport C163/15

- Tien, van der Hammen, de Vries, Schram en Steenbergen, 2017. Inspanningsadviezen voor snoekbaars, baars, blankvoorn en brasem in het IJssel-/Markermeer. IMARES rapport c018/17. 


\section{Verantwoording}

Rapportnummer:

$\mathrm{C} 018 / 18$

Projectnummer:

4318100214

Dit rapport is met grote zorgvuldigheid tot stand gekomen. De wetenschappelijke kwaliteit is intern getoetst door een collega-onderzoeker en het verantwoordelijk lid van het managementteam van Wageningen Marine Research

Akkoord:

Dr. E.U. Beier

Onderzoeker

Handtekening:

Datum:
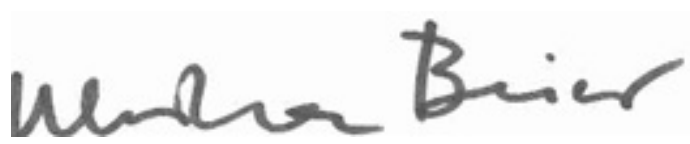

19 maart 2018

Akkoord:

Dr. Ir. T.P. Bult

Handtekening:

Datum:

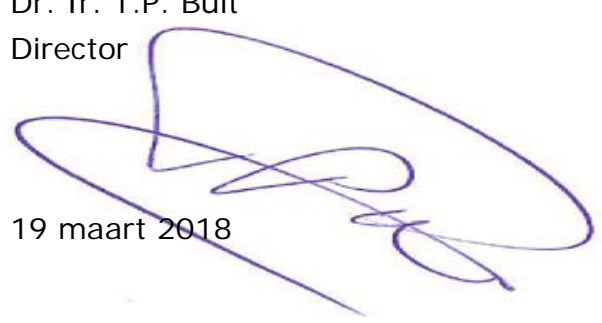




\section{Bijlage 1 Beschikbare gegevens}

De door Wageningen Marine Research uitgevoerde monitoring op het IJ sselmeer en Markermeer bevat een aantal voor dit onderzoek relevante onderdelen: een in 2011 beëindigde marktbemonstering en een visserij-onafhankelijke bemonstering van de open wateren met grote kuil/verhoogde boomkor en met de elektrokor. Daarnaast is gewerkt met de gegevens van de in 2016 gestarte marktbemonstering.

\section{Historische marktbemonstering van snoekbaars en baars}

De marktbemonstering betrof de bemonstering van commercieel aangelande baars en snoekbaars. Brasem en blankvoorn werden niet bemonsterd. Vanaf 1966 werden lengte, leeftijd, gewicht en geslacht bepaald van snoekbaars en baars. De bemonstering vond plaats in het 1e en $4 \mathrm{e}$ kwartaal, in de laatste jaren voornamelijk op Urk (in eerdere jaren ook op andere visafslagen). Door gebrek aan beschikbare vis op de afslagen werd de laatste jaren daarnaast door een visserijfirma 3x per jaar $100 \mathrm{~kg}$ snoekbaars en $50 \mathrm{~kg}$ baars van zowel het IJ sselmeer als het Markermeer geleverd aan Wageningen Marine Research. Deze vis werd in de marktbemonstering op dezelfde manier behandeld als de vis verkregen via de afslagen. De marktbemonstering is beëindigd in januari 2011.

\section{Nieuwe marktbemonstering:}

Winter 2016/2017: staand want $101 \mathrm{~mm}$

In het najaar van 2016 is een pilot marktbemonstering schubvis gestart. Medewerkers van Wageningen Marine Research zijn, verdeeld over de maanden september - december van 2017 en maart van 2018, in totaal bij 17 vaartrips te gast geweest op commerciële vissersschepen waarbij gevist werd met $101 \mathrm{~mm}$ staand want. Tijdens deze vaartrips is de gehele vangst op soort gebracht en zijn alle vissen op lengte gemeten. In oktober-december is een representatief deel van de vangst opgekocht voor biologische metingen. Het betrof hier de toenmalige doelsoorten brasem en snoekbaars waarbij de lengte, het gewicht, het geslacht, de rijpheid en de leeftijd wordt vastgesteld. Het zogenaamde snijden en meten van deze vissen vond plaats in 2017.

\section{Winter 2017/2018: zegen + staand want $101 \&$ grotere maaswijdte}

In september-december 2017 is de marktbemonstering weer uitgevoerd, maar dit jaar is de bemonstering uitgebreid: Ook is geprobeerd zegenvisserij en de visserij met staand want met grotere maaswijdtes te bemonsteren, en ook blankvoorn en baars zijn opgekocht voor biologische metingen. In totaal zijn de vangsten bemonsterd van 18 vaartrips met staandwantvisserij. Hiervan waren 16 trips met $101 \mathrm{~mm}$ maaswijdte, 1 trip met $130 \mathrm{~mm}$ en ladders (een warrelnet), en 1 met een combinatie van 130 en $190 \mathrm{~mm}$. De biologische metingen van deze reizen zijn voor de analyses van dit rapport nog niet beschikbaar. Het is in 2017 niet gelukt om mee te varen met een zegenvisser, maar begin 2018 is wel een zegenreis bemonsterd.

\footnotetext{
Visserij-onafhankelijke survey met actieve tuigen in het open water (openwatermonitoring) Grote kuil/Verhoogde boomkor

De survey is begonnen in 1966 en sinds 1989 gestandaardiseerd (van der Sluis et al. 2016). Sinds de standaardisering in 1989 vindt de bemonstering plaats in week 42-47 met 25 trekken in het IJ sselmeer en 20 trekken in het Markermeer. De bemonstering is opgezet voor het bepalen van de nieuwe aanwas van schubvis. De methodiek van de survey is daarom met name gericht op het vangen van jonge vis. De opzet van de bemonstering is zodanig dat over alle bemonsterde locaties een beeld van het bestand aan jonge vis in het IJ sselmeer en Markermeer gegeven kan worden.

De bemonstering vond tot en met 2012 plaats met een grote kuil (7.4-meter). Deze is in 2013 vervangen door een verhoogde 4-meter boomkor. Voor het koppelen van de gegevens van de twee tuigtypen is in 2012 een vergelijkend experiment uitgevoerd. Er werd geen statistisch verschil in vangstsucces tussen de twee tuigen worden aangetoond voor de vier schubvissoorten. Daarop is aangenomen dat het vangstsucces van de twee tuigen gelijk is voor alle vier soorten. Echter, de gekozen relaties tussen de twee tuigen (i.e., een 1-op-1 relatie van de vangsten) zijn met grote
} 
onzekerheid omgeven. Zo waren voor blankvoorn en brasem geen gegevens beschikbaar om een soort-specifieke relatie te bepalen. Daarom is de relatie van een grotere groep vissen gebruikt, namelijk van alle demersale (voor brasem) en alle pelagische (voor blankvoorn) vissoorten. Voor deze grotere groep vissen werd ook geen statistisch significant verschil in vangstsucces tussen de twee tuigen aangetoond. Daarom moeten de periodes voor en vanaf 2013 met grote voorzichtigheid met elkaar vergeleken worden (bijlage II van Van der Sluis et al., 2016). Een overzicht van de betrouwbaarheidsintervallen van de relatie tussen het vangstsucces van de twee tuigen van de vier soorten staat hier in bijlage 5.

\section{Elektrokor}

Naast de grote kuil/verhoogde boomkor bemonstering vindt gelijktijdige bemonstering met een elektrokor plaats. Sinds 1989 wordt met de elektrokor bemonsterd om de aal te monitoren. Met de elektrokor wordt er gestreefd om 20 stations in duplo op het IJsselmeer en 10 stations in duplo op het Markermeer te bemonsteren. Vanaf 1995 wordt er in 1 trek per station naast de aal ook de overige soorten in de vangst gesorteerd, geteld en gemeten. In 1992, 1993 en 1994 gebeurde dit slechts in een paar trekken (2, 5 en 3 respectievelijk).

In de survey wordt na elke trek van alle vissen het aantal en de lengte genoteerd. Tevens zijn in een aantal jaren ook leeftijd, gewicht en geslacht bepaald van een (lengte-gestratificeerde) selectie van de soorten. De vangstefficiëntie van de survey is niet voor alle individuen gelijk: kleine individuen worden beter gevangen dan grote individuen. 


\section{Bijlage 2 Opwerking gegevens openwatersurvey}

\section{Samenvoegen kuil/ boomkor survey met elektrokor survey}

Tot 2015 werd de index alleen aan de hand van de kuil/boomkor-survey berekend. Omdat deze survey ontwikkeld is voor juveniele vis en de vangsten van met name snoekbaars en brasem vrij laag zijn, is besloten ook de vangstgegevens van de elektrokor mee te nemen in de trendberekening. Op deze manier is de index gebaseerd op meer trekken en meer gevangen vis.

Bovenstaande opwerkingen zijn uitgevoerd met de kuil/boomkor survey en met de elektrokor survey apart, waaruit twee indices per jaar zijn gekomen. Deze twee indices zijn vervolgens bij elkaar gevoegd, met een zwaardere weging voor de kuil/boomkor survey (70\%) dan de elektrokor survey (30\%). Deze weging is gelijk aan de verhouding van de gemiddelde inspanning (bevist oppervlakte) tussen de boomkor en de elektrokor in 2013-2016. De kuil (die tot 2012 gebruikt werd) had een grotere inspanning dan de boomkor ( $\sim 0.6$ vs. 0.4$)$. Hier is geen rekening mee gehouden en de verhouding van de boomkor vs. de elektrokor is voor de hele tijdsserie aangehouden (0.7:0.3).

\section{Opwerking naar biomassa-index van gehele beviste bestand}

De gegevens van de openwatersurvey met de grote kuil/verhoogde boomkor en met de elektrokor worden opgewerkt naar aantallen per lengte per trek en per soort vanaf 1992. Gewichten worden per soort, trek en lengte berekend aan de hand van lengte-gewicht relaties zoals in de reguliere zoetwaterrapportages (van der Sluis et al., 2016). Vervolgens wordt per soort en trek het vangstgewicht over alle lengtes opgeteld. Hierna worden de vangsten per trek op basis van beviste afstand en breedte van het tuig gestandaardiseerd naar kilogram per hectare. Daarna wordt de gemiddelde bemonsterde dichtheid per meer berekend, door eerst een gemiddelde dichtheid per station te berekenen (soms wordt een station meer dan eens bemonsterd) en vervolgens de dichtheid over alle stations te middelen. Deze methode is gelijk aan de methode die in de zoetwater rapportage wordt gebruikt (van der Sluis et al., 2016) en die gebruikt is in de vorige rapportage (Tien en van der Hammen, 2016).

\section{Opwerking naar biomassa-index van paaibestand}

De relatie tussen lengte en paairijpheid is geschat, op basis van (1) gegevens uit de openwatermonitoring in de jaren 1992-2016, (2) voor snoekbaars en baars zijn gegevens uit de historische marktbemonstering, van 1992-2010 en (3) voor brasem en snoekbaars gegevens van de nieuwe marktbemonstering uit 2016. Uit de marktbemonsteringen zijn alleen de gegevens van september-december gebruikt. Deze gegevens zijn samengenomen per bestand en logistische regressie is toegepast op paairijpheid (wel/niet) per lengteklasse. Vervolgens wordt het paaibestand gedefinieerd als de vissen die groter zijn dan $L_{50 \%}$; de lengte waarbij $50 \%$ van de vissen paairijp is (Tabel B.2.1, Figuur B.2.1). De opwerking is verder identiek aan de opwerking van alle lengtes zoals hierboven beschreven.

Tabel B.2.1 De lengte waarbij 50\% van de vissen paairijp zijn.

\begin{tabular}{|l|l|}
\hline Soort & L50\% \\
\hline Baars & 15.5 \\
\hline Snoekbaars & 38.8 \\
\hline Brasem & 39.4 \\
\hline Blankvoorn & 14.6 \\
\hline
\end{tabular}



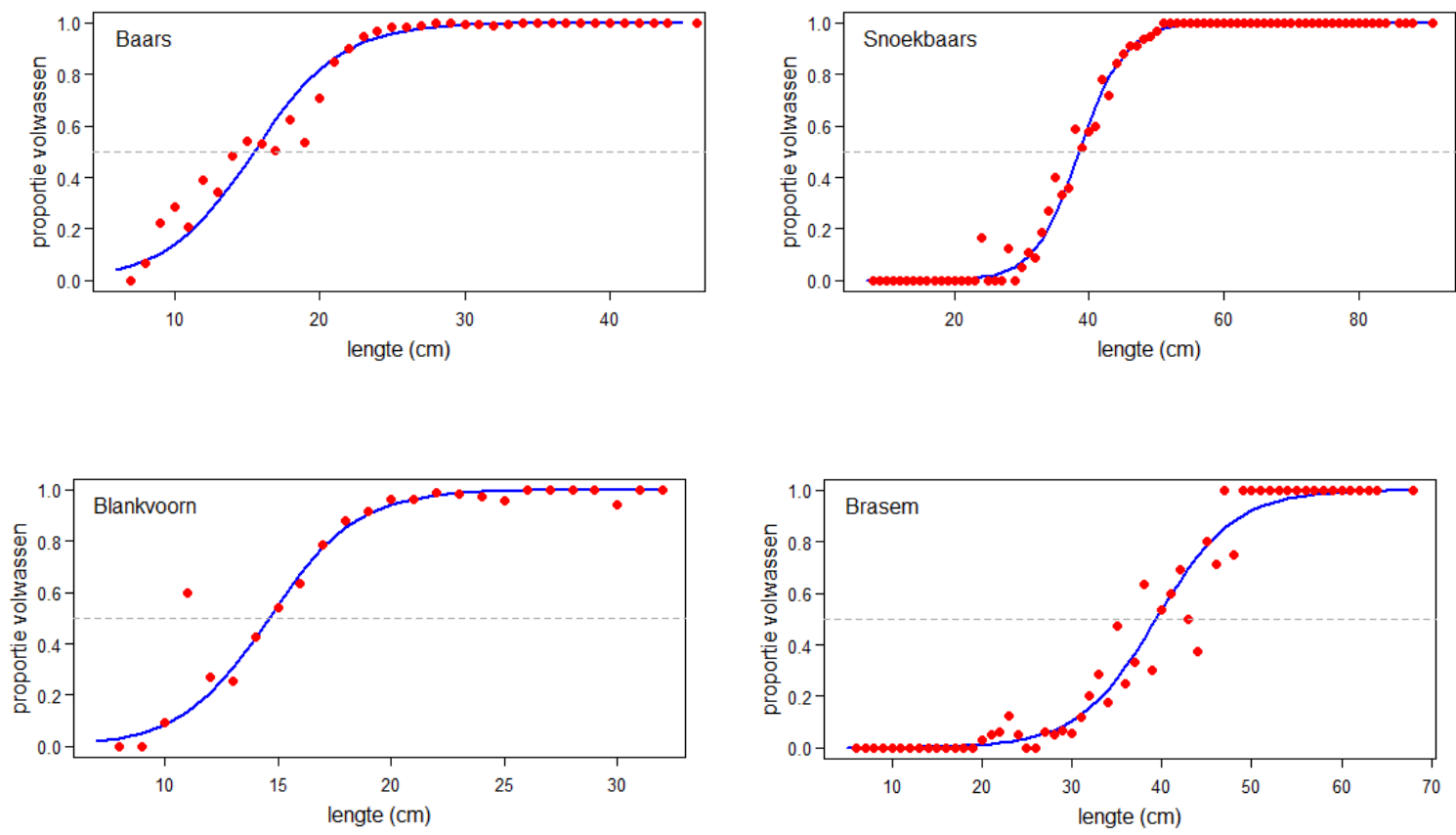

Figuur B.2.1 De gemiddelde proportie vis die volwassen (paairijp) is per lengteklasse. Gegevens van de openwatersurvey (zowel kuil/boomkor als elektrokor, van 1992-2016), de marktbemonstering voor snoekbaars en baars (1992-2010) en de marktbemonstering voor snoekbaars en brasem (2016) Rode stippen = de gemiddelde waardes per lengteklasse, blauwe lijn = de gefitte relatie door alle individuele waardes (logistische regressie). Grijze lijn $=L_{50 \%}$.

\section{Opwerking naar biomassa-index per leeftijd}

De opdeling van de surveyvangsten in vangsten van verschillende leeftijden wordt gedaan via lengteleeftijdsleutels. Hierbij zijn gegevens per soort uit dezelfde surveys beschikbaar als wat betreft de paairijpheid (vorige alinea ${ }^{3}$ ).

I dealiter wordt voor elk jaar een lengte-leeftijdsleutel gemaakt: per jaar wordt voor elke lengteklasse berekend hoeveel elke leeftijd relatief voorkomt. Voor de laatste survey (2017) zijn de leeftijden nog niet bepaald. Er is daarom voor gekozen om voor de lengte-leeftijdsleutel van 2017 een gemiddelde van de 3 jaar ervoor (2014-2016) te nemen. Daarnaast speelt mee dat niet alle andere jaren leeftijdgegevens van alle lengtes bevatten. Voor de missende lengtes in deze jaren is een gemiddelde sleutel van de hele tijdsserie genomen (1992-2016).

Vervolgens worden de gegevens van de openwatersurvey opgewerkt naar aantallen per lengte per trek en per soort voor de vier schubvissoorten vanaf 1992. Gewichten worden per soort, trek en lengte berekend aan de hand van soort-specifieke lengte-gewicht relaties zoals in de reguliere zoetwaterrapportages (van der Sluis et al., 2016). Per lengte wordt vervolgens de lengteleeftijdsleutel gebruikt om te bepalen uit welke leeftijden het gewicht van die lengte bestaat. De opwerking is verder identiek aan de opwerking zoals hierboven beschreven.

In figuur B.2.2 staan de relaties tussen paairijpheid en leeftijd.

\footnotetext{
${ }^{3}$ Hierbij geldt wel, dat de geschatte leeftijdsleutels voor brasem en snoekbaars waarschijnlijk nauwkeuriger zijn dan voor baars en blankvoorn: alleen voor de eerste twee is veel recente leeftijdsinformatie over de marktwaardige vissen beschikbaar vanuit de marktbemonstering (2016). Ook geldt voor alle soorten dat de leeftijdsleutels in 2016 nauwkeuriger zijn dan in 2017, omdat de 2017 leeftijdsgegevens nog niet beschikbaar waren bij het verschijnen van dit rapport en gebruik gemaakt werd van een gemiddelde sleutel over de jaren 2014-2016.
} 

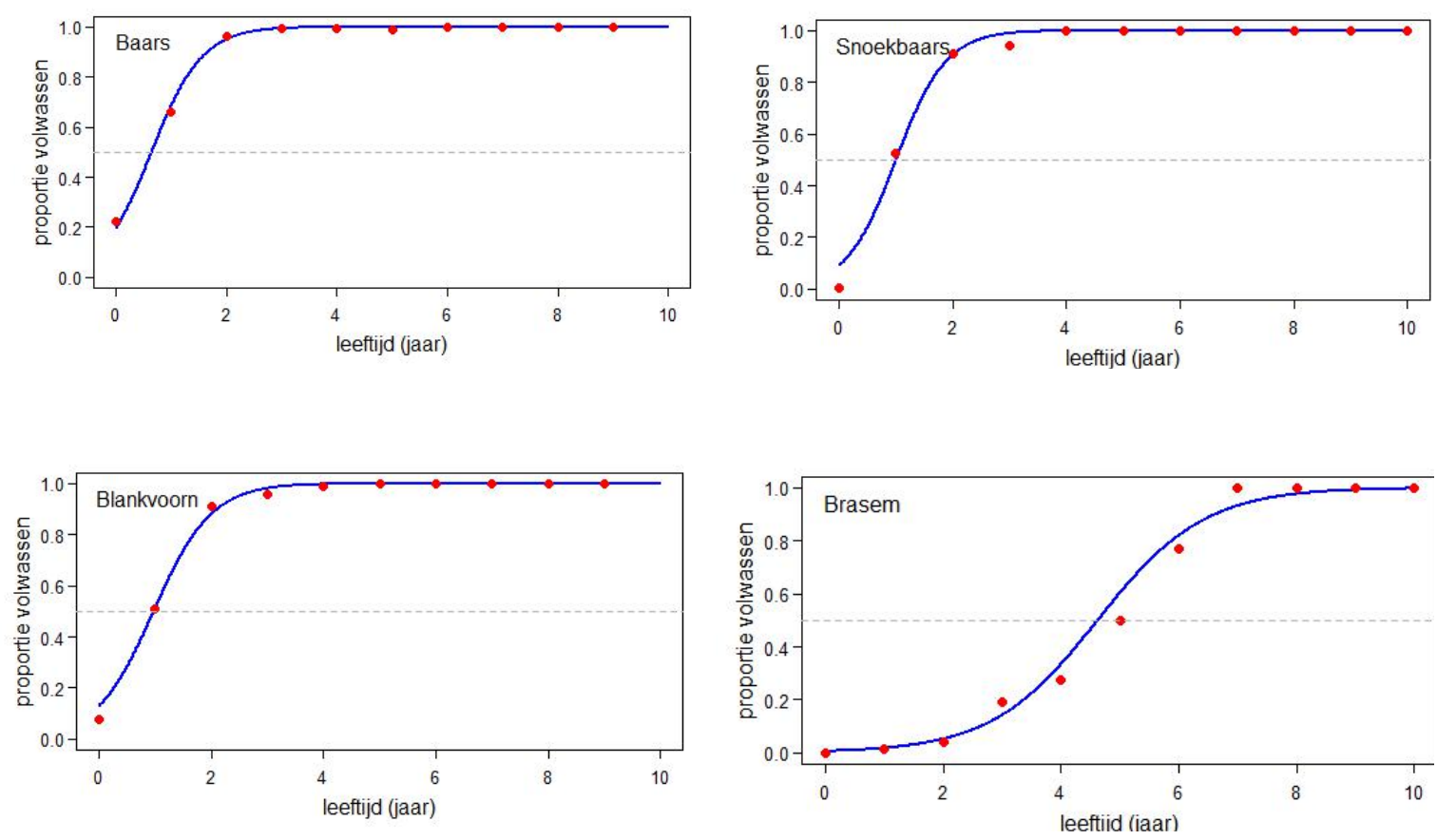

Figuur B.2.2 De gemiddelde proportie vis die volwassen (paairijp) is per leeftijdsklasse. Gegevens van de openwatersurvey (zowel kuil/boomkor als elektrokor, van 1992-2016), de marktbemonstering voor snoekbaars en baars (1992-2010) en de marktbemonstering voor snoekbaars en brasem (2016) Rode stippen = de gemiddelde waardes per leeftijdsklasse, blauwe lijn $=$ de gefitte relatie door alle individuele waardes (logistische regressie). Grijze lijn $=L_{50 \%}$.

\section{Analyse cohortontwikkelingen}

In (Tien and van der Hammen 2016) is onderzocht in hoeverre jaarklassen door de tijd heen gevolgd kunnen worden met de gegevens van de openwatersurvey: (1) Zijn jaarklassen door de jaren heen te volgen met de surveyvangsten? Dit zegt iets over de kwaliteit van de gegevens, namelijk of er voldoende vissen worden gevangen om jaarklassen te kunnen volgen. (2) Hoe representatief is een nieuwe jaarklasse voor de rest van het bestand? Met andere woorden, is er een relatie tussen de hoeveelheid nul-jarige vis en de rest van het bestand?

Uit deze analyses blijkt voor baars, blankvoorn en brasem dat jaarklassen ouder dan 0 jaar goed door de jaren heen te volgen zijn. Er is vrijwel altijd een significante correlatie tussen het gemiddelde vangstsucces in twee opeenvolgende jaren. Bijvoorbeeld, het vangstsucces van 2-jarige vis correleert goed met het vangstsucces van 3-jarige vis in het jaar erna. Echter, dit geldt niet voor snoekbaars: geen enkele leeftijdscombinatie correleert significant. Ook geldt dit niet voor de relatie tussen 0 -jarige vis en 1-jarige vis van baars, snoekbaars of blankvoorn: de hoeveelheid gevangen nieuwe aanwas toont geen relatie met de hoeveelheid 1 -jarige vis het daaropvolgende jaar. Dit is zoals verwacht voor 0 -jarige vis (zie hierboven).

Deze resultaten onderschrijven voor baars, blankvoorn en brasem (a) dat de survey een representatief beeld van de ontwikkelingen in de 1-jarige en oudere vis lijkt te geven, maar (b) dat de relatie tussen 0-jarige vis en de rest van het bestand zwak lijkt voor baars en blankvoorn, maar niet voor brasem. Samengevat zijn jaarklassen in het algemeen goed te volgen, maar heeft de hoeveelheid 0 -jarige vis weinig voorspellende waarde voor de hoeveelheid 1-jarige vis het jaar erop volgend. Echter, (c) voor snoekbaars geldt dit niet: voor geen enkele combinatie van leeftijden worden significante relaties gevonden in de consistentie-indices. Snoekbaars ouder dan 0 jaar wordt waarschijnlijk in te lage aantallen gevangen om nauwkeurig trends in afzonderlijke jaarklassen te volgen. De vangbaarheid van 1-jarige en oudere snoekbaars in de survey lijkt dus erg laag te zijn.

\section{Ontwikkelingen in doorzicht ten tijde van de openwatermonitoring}

In de vorige rapportage is naar effecten van doorzicht gekeken (Tien et al. 2017, en een samenvatting in hoofdstuk 2.1 van dit rapport). Hieruit bleek dat voor alle vier bestanden doorzicht een rol speelt in het verklaren van het vangstsucces van een trek. Maar voor de trend bleek het nauwelijks een rol te 
spelen doordat de variatie in doorzicht binnen een jaar vele malen groter was dan tussen jaren. Het is echter wel van belang om de trends in doorzicht te blijven volgen.

Tijdens de survey wordt het doorzicht gemeten direct na een trek. Uit de doorzichtgegevens van de survey, blijkt dat het doorzicht erg fluctueert binnen een surveyjaar, maar nauwelijks toeneemt door de jaren heen. 2014-2016 waren jaren met relatief hoge doorzicht, maar in 2017 is dit gemiddelde doorzicht weer sterk afgenomen (figuur B.2.3), terug naar het niveau van de jaren ervoor.

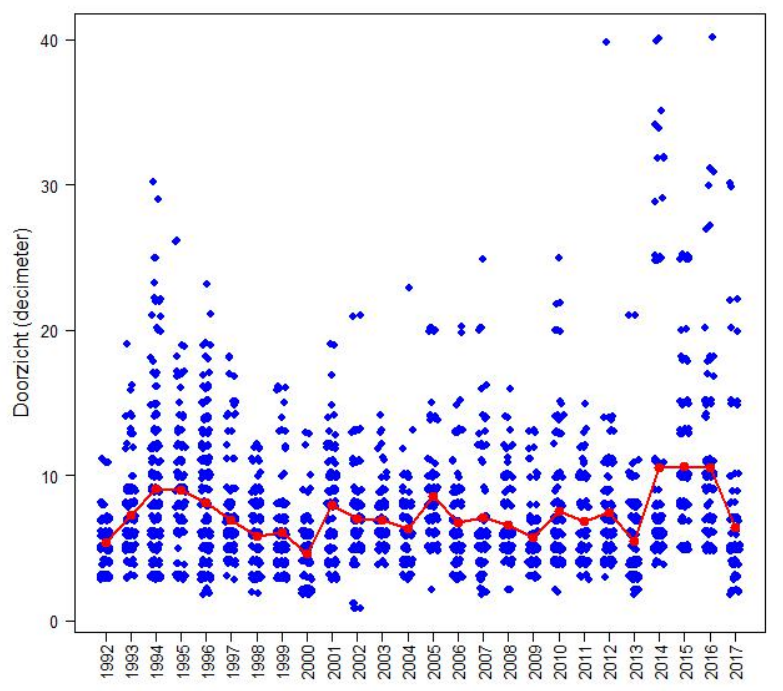

Figuur B.2.3 Doorzicht in de survey. Blauwe punten zijn de waargenomen data, de rode lijn is het gemiddelde van alle trekken. 


\section{Bijlage 3 Aantal gevangen vissen in de openwatersurvey}

Het aantal gevangen vissen in openwatersurvey met de grote kuil/verhoogde boomkor en met de elektrokor. Opgedeeld in juveniel en adult, en als totaal. In 2013 is overgestapt van grote kuil op verhoogde boomkor.

\section{Baars}

\begin{tabular}{|c|c|c|c|c|c|c|}
\hline \multirow[b]{2}{*}{ jaar } & \multicolumn{3}{|c|}{ Kuil/Boomkor } & \multicolumn{3}{|c|}{ Elektrokor } \\
\hline & juveniel & adult & totaal & juveniel & adult & totaal \\
\hline 1992 & 5785 & 1693 & 7478 & 2764 & 174 & 2938 \\
\hline 1993 & 6058 & 885 & 6943 & 256 & 29 & 285 \\
\hline 1994 & 3912 & 2223 & 6135 & 2774 & 1021 & 3795 \\
\hline 1995 & 3427 & 2285 & 5712 & 3549 & 825 & 4374 \\
\hline 1996 & 3159 & 1779 & 4938 & 5497 & 1397 & 6894 \\
\hline 1997 & 2454 & 1209 & 3663 & 6540 & 1161 & 7701 \\
\hline 1998 & 2032 & 2366 & 4398 & 1443 & 830 & 2273 \\
\hline 1999 & 2959 & 2226 & 5185 & 3394 & 1449 & 4843 \\
\hline 2000 & 2964 & 1721 & 4685 & 1872 & 448 & 2320 \\
\hline 2001 & 1984 & 1698 & 3682 & 1397 & 629 & 2026 \\
\hline 2002 & 1488 & 1236 & 2724 & 1156 & 658 & 1814 \\
\hline 2003 & 1655 & 1206 & 2861 & 1346 & 771 & 2117 \\
\hline 2004 & 2557 & 950 & 3507 & 1710 & 444 & 2154 \\
\hline 2005 & 2056 & 1277 & 3333 & 1310 & 571 & 1881 \\
\hline 2006 & 1273 & 1038 & 2311 & 685 & 211 & 896 \\
\hline 2007 & 1202 & 955 & 2157 & 658 & 253 & 911 \\
\hline 2008 & 1202 & 578 & 1780 & 859 & 222 & 1081 \\
\hline 2009 & 1083 & 996 & 2079 & 663 & 404 & 1067 \\
\hline 2010 & 1701 & 1312 & 3013 & 974 & 273 & 1247 \\
\hline 2011 & 1164 & 242 & 1406 & 888 & 123 & 1011 \\
\hline 2012 & 1908 & 1783 & 3691 & 566 & 292 & 858 \\
\hline 2013 & 1777 & 454 & 2231 & 829 & 57 & 886 \\
\hline 2014 & 1063 & 389 & 1452 & 765 & 119 & 884 \\
\hline 2015 & 943 & 130 & 1073 & 567 & 7 & 574 \\
\hline 2016 & 970 & 643 & 1613 & 408 & 213 & 621 \\
\hline 2017 & 1473 & 581 & 2054 & 839 & 126 & 965 \\
\hline
\end{tabular}


Snoekbaars

\begin{tabular}{|c|c|c|c|c|c|c|}
\hline \multirow[b]{2}{*}{ jaar } & \multicolumn{3}{|c|}{ Kuil/Boomkor } & \multicolumn{3}{|c|}{ Elektrokor } \\
\hline & juveniel & adult & totaal & juveniel & adult & totaal \\
\hline 1992 & 2150 & 2 & 2152 & 82 & 0 & 82 \\
\hline 1993 & 916 & 6 & 922 & 9 & 0 & 9 \\
\hline 1994 & 1701 & 11 & 1712 & 291 & 0 & 291 \\
\hline 1995 & 1004 & 17 & 1021 & 304 & 1 & 305 \\
\hline 1996 & 528 & 5 & 533 & 272 & 1 & 273 \\
\hline 1997 & 947 & 14 & 961 & 561 & 5 & 566 \\
\hline 1998 & 1333 & 3 & 1336 & 178 & 1 & 179 \\
\hline 1999 & 1475 & 19 & 1494 & 344 & 2 & 346 \\
\hline 2000 & 1374 & 68 & 1442 & 160 & 6 & 166 \\
\hline 2001 & 1344 & 20 & 1364 & 397 & 2 & 399 \\
\hline 2002 & 604 & 43 & 647 & 94 & 1 & 95 \\
\hline 2003 & 763 & 2 & 765 & 318 & 0 & 318 \\
\hline 2004 & 932 & 9 & 941 & 470 & 0 & 470 \\
\hline 2005 & 700 & 9 & 709 & 190 & 0 & 190 \\
\hline 2006 & 981 & 1 & 982 & 68 & 0 & 68 \\
\hline 2007 & 847 & 12 & 859 & 113 & 2 & 115 \\
\hline 2008 & 495 & 8 & 503 & 167 & 1 & 168 \\
\hline 2009 & 940 & 10 & 950 & 279 & 2 & 281 \\
\hline 2010 & 593 & 2 & 595 & 200 & 1 & 201 \\
\hline 2011 & 465 & 1 & 466 & 201 & 0 & 201 \\
\hline 2012 & 576 & 2 & 578 & 61 & 0 & 61 \\
\hline 2013 & 822 & 1 & 823 & 84 & 0 & 84 \\
\hline 2014 & 377 & 1 & 378 & 298 & 1 & 299 \\
\hline 2015 & 453 & 8 & 461 & 210 & 0 & 210 \\
\hline 2016 & 258 & 6 & 264 & 47 & 0 & 47 \\
\hline 2017 & 963 & 8 & 971 & 247 & 1 & 248 \\
\hline
\end{tabular}


Blankvoorn

\begin{tabular}{|c|c|c|c|c|c|c|}
\hline \multirow[b]{2}{*}{ jaar } & \multicolumn{3}{|c|}{ Kuil/Boomkor } & \multicolumn{3}{|c|}{ Elektrokor } \\
\hline & juveniel & adult & totaal & juveniel & adult & totaal \\
\hline 1992 & 2337 & 1897 & 4234 & 425 & 105 & 530 \\
\hline 1993 & 1267 & 981 & 2248 & 21 & 23 & 44 \\
\hline 1994 & 1732 & 1096 & 2828 & 1912 & 333 & 2245 \\
\hline 1995 & 2015 & 910 & 2925 & 1174 & 195 & 1369 \\
\hline 1996 & 1041 & 1862 & 2903 & 607 & 793 & 1400 \\
\hline 1997 & 1730 & 1088 & 2818 & 2122 & 535 & 2657 \\
\hline 1998 & 1288 & 945 & 2233 & 328 & 121 & 449 \\
\hline 1999 & 962 & 1238 & 2200 & 746 & 220 & 966 \\
\hline 2000 & 711 & 656 & 1367 & 190 & 82 & 272 \\
\hline 2001 & 509 & 705 & 1214 & 259 & 97 & 356 \\
\hline 2002 & 816 & 455 & 1271 & 422 & 114 & 536 \\
\hline 2003 & 743 & 534 & 1277 & 452 & 273 & 725 \\
\hline 2004 & 801 & 1078 & 1879 & 434 & 241 & 675 \\
\hline 2005 & 765 & 823 & 1588 & 305 & 87 & 392 \\
\hline 2006 & 1265 & 540 & 1805 & 394 & 55 & 449 \\
\hline 2007 & 793 & 853 & 1646 & 324 & 184 & 508 \\
\hline 2008 & 861 & 492 & 1353 & 451 & 58 & 509 \\
\hline 2009 & 1068 & 556 & 1624 & 457 & 123 & 580 \\
\hline 2010 & 1127 & 753 & 1880 & 364 & 132 & 496 \\
\hline 2011 & 356 & 233 & 589 & 250 & 64 & 314 \\
\hline 2012 & 431 & 239 & 670 & 153 & 12 & 165 \\
\hline 2013 & 629 & 215 & 844 & 254 & 38 & 292 \\
\hline 2014 & 289 & 107 & 396 & 210 & 32 & 242 \\
\hline 2015 & 322 & 55 & 377 & 200 & 47 & 247 \\
\hline 2016 & 509 & 93 & 602 & 135 & 10 & 145 \\
\hline 2017 & 211 & 495 & 706 & 73 & 89 & 162 \\
\hline
\end{tabular}


Brasem

\begin{tabular}{|c|c|c|c|c|c|c|}
\hline \multirow[b]{2}{*}{ jaar } & \multicolumn{3}{|c|}{ Kuil/Boomkor } & \multicolumn{3}{|c|}{ Elektrokor } \\
\hline & juveniel & adult & totaal & juveniel & adult & totaal \\
\hline 1992 & 1566 & 66 & 1632 & 31 & 7 & 38 \\
\hline 1993 & 682 & 248 & 930 & 6 & 0 & 6 \\
\hline 1994 & 848 & 237 & 1085 & 359 & 23 & 382 \\
\hline 1995 & 2504 & 633 & 3137 & 492 & 32 & 524 \\
\hline 1996 & 1055 & 400 & 1455 & 283 & 27 & 310 \\
\hline 1997 & 1539 & 222 & 1761 & 692 & 52 & 744 \\
\hline 1998 & 1036 & 177 & 1213 & 115 & 58 & 173 \\
\hline 1999 & 1360 & 357 & 1717 & 511 & 15 & 526 \\
\hline 2000 & 1006 & 149 & 1155 & 122 & 29 & 151 \\
\hline 2001 & 778 & 143 & 921 & 128 & 46 & 174 \\
\hline 2002 & 592 & 47 & 639 & 158 & 2 & 160 \\
\hline 2003 & 496 & 221 & 717 & 89 & 10 & 99 \\
\hline 2004 & 402 & 39 & 441 & 63 & 16 & 79 \\
\hline 2005 & 326 & 114 & 440 & 60 & 8 & 68 \\
\hline 2006 & 434 & 38 & 472 & 59 & 2 & 61 \\
\hline 2007 & 409 & 21 & 430 & 41 & 1 & 42 \\
\hline 2008 & 197 & 4 & 201 & 119 & 0 & 119 \\
\hline 2009 & 289 & 13 & 302 & 62 & 5 & 67 \\
\hline 2010 & 356 & 6 & 362 & 82 & 0 & 82 \\
\hline 2011 & 44 & 2 & 46 & 22 & 0 & 22 \\
\hline 2012 & 229 & 7 & 236 & 29 & 0 & 29 \\
\hline 2013 & 110 & 3 & 113 & 88 & 0 & 88 \\
\hline 2014 & 111 & 0 & 111 & 64 & 0 & 64 \\
\hline 2015 & 32 & 0 & 32 & 12 & 0 & 12 \\
\hline 2016 & 147 & 4 & 151 & 33 & 0 & 33 \\
\hline 2017 & 187 & 8 & 195 & 68 & 0 & 68 \\
\hline
\end{tabular}




\section{Bijlage 4 Biomassa-index-waardes}

\section{Baars}

Waardes voor de biomassa-indices voor baars, voor het IJ sselmeer en Markermeer gecombineerd. Voor de kuil/boomkor, de elektrokor en de gecombineerde tuigen. In totaal en opgedeeld in volwassen (paairijp) en juveniele vissen. De survey-indices betreffen de gemiddelde biomassa-dichtheid (kilogram per hectare) over alle trekken van de openwatersurvey. In de kuil/boomkor survey is van 2012 op 2013 gewisseld van tuig, van grote kuil naar verhoogde boomkor. De maturity index (zie bijlage 2) wordt elk jaar opnieuw berekend, waarbij de nieuwste gegevens worden toegevoegd. Daarom kunnen de waarden van juvenielen en adulten van voorgaande jaren elk jaar iets veranderen.

\begin{tabular}{|c|c|c|c|c|c|c|c|c|c|}
\hline \multirow[b]{2}{*}{ jaar } & \multicolumn{3}{|c|}{ Kuil/Boomkor } & \multicolumn{3}{|c|}{ Elektrokor } & \multicolumn{3}{|c|}{ Gecombineerd } \\
\hline & juveniel & adult & totaal & juveniel & adult & totaal & juveniel & adult & totaal \\
\hline 1992 & 17.06 & 10.73 & 27.79 & 17.74 & 3.31 & 21.06 & 17.26 & 8.51 & 25.77 \\
\hline 1993 & 6.29 & 3.19 & 9.48 & 3.09 & 3.20 & 6.28 & 5.33 & 3.19 & 8.52 \\
\hline 1994 & 5.05 & 7.38 & 12.43 & 4.60 & 3.17 & 7.77 & 4.92 & 6.12 & 11.03 \\
\hline 1995 & 2.74 & 10.05 & 12.79 & 3.77 & 10.51 & 14.27 & 3.05 & 10.19 & 13.24 \\
\hline 1996 & 11.19 & 7.84 & 19.03 & 12.60 & 6.07 & 18.67 & 11.61 & 7.31 & 18.92 \\
\hline 1997 & 10.00 & 6.55 & 16.54 & 16.44 & 5.28 & 21.72 & 11.93 & 6.17 & 18.10 \\
\hline 1998 & 7.18 & 11.02 & 18.20 & 7.25 & 10.26 & 17.51 & 7.20 & 10.79 & 17.99 \\
\hline 1999 & 6.33 & 7.57 & 13.91 & 8.81 & 8.14 & 16.95 & 7.08 & 7.74 & 14.82 \\
\hline 2000 & 6.24 & 6.89 & 13.13 & 8.05 & 4.33 & 12.38 & 6.78 & 6.12 & 12.90 \\
\hline 2001 & 7.33 & 7.72 & 15.05 & 9.98 & 5.86 & 15.85 & 8.13 & 7.16 & 15.29 \\
\hline 2002 & 5.87 & 6.29 & 12.16 & 15.26 & 8.46 & 23.72 & 8.69 & 6.94 & 15.63 \\
\hline 2003 & 9.01 & 6.49 & 15.50 & 52.26 & 13.87 & 66.13 & 21.98 & 8.70 & 30.69 \\
\hline 2004 & 20.05 & 3.91 & 23.96 & 40.68 & 6.04 & 46.72 & 26.24 & 4.55 & 30.79 \\
\hline 2005 & 3.84 & 3.46 & 7.30 & 11.68 & 4.40 & 16.08 & 6.20 & 3.74 & 9.94 \\
\hline 2006 & 3.93 & 2.71 & 6.64 & 3.35 & 1.62 & 4.97 & 3.76 & 2.38 & 6.14 \\
\hline 2007 & 8.41 & 3.12 & 11.53 & 36.60 & 3.56 & 40.16 & 16.87 & 3.25 & 20.12 \\
\hline 2008 & 6.03 & 3.87 & 9.90 & 11.01 & 3.04 & 14.05 & 7.53 & 3.62 & 11.15 \\
\hline 2009 & 4.01 & 3.78 & 7.80 & 3.40 & 2.96 & 6.35 & 3.83 & 3.54 & 7.37 \\
\hline 2010 & 7.48 & 5.16 & 12.63 & 4.65 & 2.46 & 7.12 & 6.63 & 4.35 & 10.98 \\
\hline 2011 & 3.42 & 0.80 & 4.21 & 9.27 & 1.25 & 10.52 & 5.17 & 0.93 & 6.11 \\
\hline 2012 & 2.53 & 4.20 & 6.73 & 1.53 & 3.16 & 4.69 & 2.23 & 3.89 & 6.12 \\
\hline 2013 & 12.38 & 1.68 & 14.06 & 8.57 & 0.78 & 9.35 & 11.24 & 1.41 & 12.64 \\
\hline 2014 & 18.82 & 4.56 & 23.38 & 7.91 & 1.87 & 9.79 & 15.55 & 3.75 & 19.30 \\
\hline 2015 & 15.09 & 0.98 & 16.07 & 12.58 & 0.14 & 12.72 & 14.34 & 0.73 & 15.07 \\
\hline 2016 & 6.68 & 10.38 & 17.05 & 1.14 & 2.49 & 4.37 & 5.02 & 8.01 & 13.25 \\
\hline 2017 & 20.12 & 3.84 & 23.96 & 14.15 & 1.86 & 16.01 & 18.33 & 3.25 & 21.58 \\
\hline
\end{tabular}




\section{Snoekbaars}

Onderliggende waardes voor de survey-indices voor snoekbaars, voor het IJ sselmeer en Markermeer gecombineerd. Voor de kuil/boomkor, de elektrokor en de gecombineerde index. In totaal en opgedeeld in volwassen (paairijp) en juveniele vissen. De survey-indices betreffen de gemiddelde biomassa-dichtheid (kilogram per hectare) over alle trekken van de openwatersurvey. In de kuil/boomkor survey is van 2012 op 2013 gewisseld van tuig, van grote kuil naar verhoogde boomkor.

\begin{tabular}{|c|c|c|c|c|c|c|c|c|c|}
\hline \multirow[b]{2}{*}{ jaar } & \multicolumn{3}{|c|}{ Kuil/Boomkor } & \multicolumn{3}{|c|}{ Elektrokor } & \multicolumn{3}{|c|}{ Gecombineerd } \\
\hline & juveniel & adult & totaal & juveniel & adult & totaal & juveniel & adult & totaal \\
\hline 1992 & 3.68 & 0.10 & 3.78 & 1.20 & 0.00 & 1.20 & 2.93 & 0.07 & 3.00 \\
\hline 1993 & 1.85 & 0.53 & 2.39 & 0.64 & 0.00 & 0.64 & 1.49 & 0.37 & 1.86 \\
\hline 1994 & 2.55 & 0.21 & 2.76 & 1.16 & 0.00 & 1.16 & 2.13 & 0.15 & 2.28 \\
\hline 1995 & 3.86 & 0.10 & 3.96 & 1.93 & 0.00 & 1.93 & 3.28 & 0.07 & 3.35 \\
\hline 1996 & 0.75 & 0.14 & 0.89 & 0.30 & 0.00 & 0.30 & 0.62 & 0.10 & 0.72 \\
\hline 1997 & 2.52 & 2.03 & 4.56 & 1.14 & 0.00 & 1.14 & 2.11 & 1.42 & 3.53 \\
\hline 1998 & 1.21 & 0.06 & 1.27 & 0.87 & 0.00 & 0.87 & 1.11 & 0.04 & 1.15 \\
\hline 1999 & 2.57 & 0.36 & 2.93 & 1.68 & 0.14 & 1.82 & 2.30 & 0.30 & 2.60 \\
\hline 2000 & 2.68 & 0.78 & 3.47 & 1.11 & 0.52 & 1.62 & 2.21 & 0.70 & 2.92 \\
\hline 2001 & 4.77 & 0.14 & 4.91 & 2.30 & 0.14 & 2.45 & 4.03 & 0.14 & 4.17 \\
\hline 2002 & 1.80 & 1.55 & 3.35 & 0.73 & 0.06 & 0.80 & 1.48 & 1.10 & 2.58 \\
\hline 2003 & 3.64 & 0.03 & 3.67 & 2.33 & 0.00 & 2.33 & 3.25 & 0.02 & 3.27 \\
\hline 2004 & 1.20 & 0.11 & 1.31 & 2.15 & 0.00 & 2.15 & 1.48 & 0.07 & 1.56 \\
\hline 2005 & 2.25 & 0.25 & 2.51 & 1.58 & 0.00 & 1.58 & 2.05 & 0.18 & 2.23 \\
\hline 2006 & 1.49 & 0.01 & 1.51 & 0.38 & 0.00 & 0.38 & 1.16 & 0.01 & 1.17 \\
\hline 2007 & 1.84 & 0.15 & 1.99 & 0.61 & 0.00 & 0.61 & 1.47 & 0.10 & 1.57 \\
\hline 2008 & 1.84 & 0.48 & 2.32 & 1.87 & 0.00 & 1.87 & 1.85 & 0.34 & 2.19 \\
\hline 2009 & 3.21 & 0.15 & 3.36 & 1.69 & 0.20 & 1.90 & 2.75 & 0.17 & 2.92 \\
\hline 2010 & 2.61 & 0.06 & 2.67 & 1.04 & 0.10 & 1.14 & 2.14 & 0.07 & 2.21 \\
\hline 2011 & 0.53 & 0.02 & 0.55 & 1.33 & 0.00 & 1.33 & 0.77 & 0.01 & 0.78 \\
\hline 2012 & 0.68 & 0.03 & 0.72 & 0.34 & 0.00 & 0.34 & 0.58 & 0.02 & 0.60 \\
\hline 2013 & 1.88 & 0.00 & 1.88 & 0.47 & 0.00 & 0.47 & 1.46 & 0.00 & 1.46 \\
\hline 2014 & 3.72 & 0.00 & 3.72 & 1.35 & 0.07 & 1.42 & 3.01 & 0.02 & 3.03 \\
\hline 2015 & 1.34 & 0.21 & 1.55 & 0.55 & 0.00 & 0.55 & 1.10 & 0.15 & 1.25 \\
\hline 2016 & 1.40 & 0.15 & 1.54 & 0.40 & 0.00 & 0.54 & 1.10 & 0.11 & 1.24 \\
\hline 2017 & 4.82 & 0.24 & 5.06 & 1.62 & 0.00 & 1.62 & 3.86 & 0.17 & 4.03 \\
\hline
\end{tabular}




\section{Blankvoorn}

Onderliggende waardes voor de survey-indices voor blankvoorn, voor het IJ sselmeer en Markermeer gecombineerd. Voor de kuil/boomkor, de elektrokor en de gecombineerde index. In totaal en opgedeeld in volwassen (paairijp) en juveniele vissen. De survey-indices betreffen de gemiddelde biomassa-dichtheid (kilogram per hectare) over alle trekken van de openwatersurvey. In de kuil/boomkor survey is van 2012 op 2013 gewisseld van tuig, van grote kuil naar verhoogde boomkor.

\begin{tabular}{|c|c|c|c|c|c|c|c|c|c|}
\hline \multirow[b]{2}{*}{ jaar } & \multicolumn{3}{|c|}{ Kuil/Boomkor } & \multicolumn{3}{|c|}{ Elektrokor } & \multicolumn{3}{|c|}{ Gecombineerd } \\
\hline & juveniel & adult & totaal & juveniel & adult & totaal & juveniel & adult & totaal \\
\hline 1992 & 2.08 & 12.00 & 14.08 & 2.09 & 6.51 & 8.60 & 2.08 & 10.36 & 12.44 \\
\hline 1993 & 0.76 & 12.79 & 13.55 & 0.27 & 1.88 & 2.15 & 0.62 & 9.52 & 10.13 \\
\hline 1994 & 1.29 & 3.73 & 5.01 & 2.12 & 1.36 & 3.48 & 1.54 & 3.02 & 4.55 \\
\hline 1995 & 2.71 & 4.14 & 6.85 & 1.88 & 2.46 & 4.33 & 2.46 & 3.64 & 6.10 \\
\hline 1996 & 0.90 & 7.76 & 8.66 & 0.67 & 3.16 & 3.83 & 0.83 & 6.38 & 7.22 \\
\hline 1997 & 0.77 & 4.92 & 5.69 & 0.58 & 1.81 & 2.39 & 0.72 & 3.99 & 4.70 \\
\hline 1998 & 2.39 & 9.77 & 12.16 & 0.53 & 1.68 & 2.21 & 1.83 & 7.34 & 9.17 \\
\hline 1999 & 0.39 & 4.16 & 4.55 & 0.37 & 1.52 & 1.89 & 0.38 & 3.37 & 3.75 \\
\hline 2000 & 0.58 & 1.97 & 2.55 & 0.46 & 0.98 & 1.44 & 0.54 & 1.67 & 2.22 \\
\hline 2001 & 0.25 & 2.59 & 2.84 & 0.17 & 0.98 & 1.15 & 0.23 & 2.10 & 2.33 \\
\hline 2002 & 0.52 & 1.49 & 2.01 & 0.72 & 1.36 & 2.08 & 0.58 & 1.45 & 2.03 \\
\hline 2003 & 1.01 & 2.75 & 3.77 & 1.34 & 2.80 & 4.14 & 1.11 & 2.77 & 3.88 \\
\hline 2004 & 1.50 & 6.86 & 8.36 & 1.20 & 2.71 & 3.90 & 1.41 & 5.61 & 7.02 \\
\hline 2005 & 0.74 & 4.11 & 4.86 & 0.57 & 1.07 & 1.64 & 0.69 & 3.20 & 3.89 \\
\hline 2006 & 1.23 & 1.50 & 2.73 & 0.73 & 0.56 & 1.30 & 1.08 & 1.22 & 2.30 \\
\hline 2007 & 1.27 & 3.61 & 4.89 & 2.06 & 1.53 & 3.58 & 1.51 & 2.99 & 4.49 \\
\hline 2008 & 3.43 & 2.16 & 5.59 & 3.34 & 0.83 & 4.17 & 3.40 & 1.76 & 5.16 \\
\hline 2009 & 0.63 & 1.69 & 2.32 & 0.76 & 1.36 & 2.13 & 0.67 & 1.59 & 2.26 \\
\hline 2010 & 1.32 & 3.12 & 4.44 & 0.60 & 1.28 & 1.88 & 1.11 & 2.57 & 3.67 \\
\hline 2011 & 0.58 & 0.94 & 1.52 & 0.71 & 0.99 & 1.70 & 0.62 & 0.96 & 1.58 \\
\hline 2012 & 0.24 & 0.63 & 0.86 & 0.15 & 0.12 & 0.27 & 0.21 & 0.48 & 0.69 \\
\hline 2013 & 0.55 & 0.99 & 1.54 & 0.38 & 0.41 & 0.80 & 0.50 & 0.81 & 1.32 \\
\hline 2014 & 2.81 & 0.78 & 3.59 & 0.37 & 0.34 & 0.72 & 2.08 & 0.65 & 2.73 \\
\hline 2015 & 0.56 & 0.40 & 0.96 & 0.31 & 0.46 & 0.77 & 0.48 & 0.42 & 0.90 \\
\hline 2016 & 0.86 & 0.34 & 1.20 & 0.16 & 0.05 & 0.22 & 0.65 & 0.25 & 0.91 \\
\hline 2017 & 0.39 & 3.28 & 3.67 & 0.23 & 1.11 & 1.34 & 0.34 & 2.63 & 2.97 \\
\hline
\end{tabular}




\section{Brasem}

Onderliggende waardes voor de survey-indices voor brasem, voor het IJ sselmeer en Markermeer gecombineerd. Voor de kuil/boomkor, de elektrokor en de gecombineerde index. In totaal en opgedeeld in volwassen (paairijp) en juveniele vissen. De survey-indices betreffen de gemiddelde biomassa-dichtheid (kilogram per hectare) over alle trekken van de openwatersurvey. In de kuil/boomkor survey is van 2012 op 2013 gewisseld van tuig, van grote kuil naar verhoogde boomkor.

\begin{tabular}{|c|c|c|c|c|c|c|c|c|c|}
\hline \multirow[b]{2}{*}{ jaar } & \multicolumn{3}{|c|}{ Boomkor } & \multicolumn{3}{|c|}{ Elektrokor } & \multicolumn{3}{|c|}{ Gecombineerd } \\
\hline & juveniel & adult & totaal & juveniel & adult & totaal & juveniel & adult & totaal \\
\hline 1992 & 4.24 & 4.49 & 8.72 & 0.68 & 0.00 & 0.68 & 3.17 & 3.14 & 6.31 \\
\hline 1993 & 5.74 & 5.19 & 10.93 & 0.26 & 0.00 & 0.26 & 4.10 & 3.63 & 7.73 \\
\hline 1994 & 5.86 & 6.43 & 12.29 & 0.17 & 0.00 & 0.17 & 4.15 & 4.50 & 8.65 \\
\hline 1995 & 8.38 & 8.75 & 17.13 & 2.51 & 1.53 & 4.04 & 6.62 & 6.58 & 13.20 \\
\hline 1996 & 5.08 & 11.20 & 16.28 & 0.86 & 1.73 & 2.59 & 3.81 & 8.36 & 12.17 \\
\hline 1997 & 7.31 & 6.43 & 13.74 & 1.54 & 0.87 & 2.41 & 5.58 & 4.76 & 10.34 \\
\hline 1998 & 5.96 & 3.12 & 9.08 & 2.88 & 7.76 & 10.64 & 5.04 & 4.51 & 9.55 \\
\hline 1999 & 5.11 & 16.34 & 21.44 & 2.38 & 0.82 & 3.20 & 4.29 & 11.68 & 15.97 \\
\hline 2000 & 3.50 & 4.64 & 8.13 & 1.54 & 3.48 & 5.02 & 2.91 & 4.29 & 7.20 \\
\hline 2001 & 6.05 & 3.54 & 9.58 & 0.81 & 5.58 & 6.40 & 4.48 & 4.15 & 8.63 \\
\hline 2002 & 1.87 & 1.72 & 3.59 & 0.68 & 0.19 & 0.87 & 1.51 & 1.26 & 2.77 \\
\hline 2003 & 3.84 & 4.48 & 8.32 & 0.64 & 2.35 & 2.98 & 2.88 & 3.84 & 6.72 \\
\hline 2004 & 2.88 & 1.71 & 4.59 & 0.56 & 2.27 & 2.82 & 2.18 & 1.88 & 4.06 \\
\hline 2005 & 1.67 & 5.85 & 7.52 & 0.34 & 1.51 & 1.85 & 1.27 & 4.55 & 5.82 \\
\hline 2006 & 0.62 & 0.66 & 1.28 & 0.12 & 0.51 & 0.63 & 0.47 & 0.62 & 1.09 \\
\hline 2007 & 1.72 & 0.16 & 1.88 & 0.29 & 0.38 & 0.67 & 1.29 & 0.22 & 1.52 \\
\hline 2008 & 0.63 & 0.22 & 0.85 & 1.04 & 0.00 & 1.04 & 0.76 & 0.15 & 0.91 \\
\hline 2009 & 0.89 & 0.12 & 1.02 & 0.44 & 0.23 & 0.67 & 0.76 & 0.16 & 0.91 \\
\hline 2010 & 0.37 & 0.21 & 0.58 & 0.17 & 0.00 & 0.17 & 0.31 & 0.14 & 0.46 \\
\hline 2011 & 0.07 & 0.18 & 0.24 & 0.09 & 0.00 & 0.09 & 0.07 & 0.12 & 0.20 \\
\hline 2012 & 0.16 & 0.29 & 0.45 & 0.05 & 0.00 & 0.05 & 0.13 & 0.20 & 0.33 \\
\hline 2013 & 0.16 & 0.28 & 0.44 & 0.22 & 0.00 & 0.22 & 0.18 & 0.19 & 0.37 \\
\hline 2014 & 0.55 & 0.00 & 0.55 & 0.15 & 0.00 & 0.15 & 0.43 & 0.00 & 0.43 \\
\hline 2015 & 0.16 & 0.00 & 0.16 & 0.03 & 0.00 & 0.03 & 0.12 & 0.00 & 0.12 \\
\hline 2016 & 0.70 & 0.00 & 0.70 & 0.06 & 0.00 & 0.12 & 0.51 & 0.00 & 0.53 \\
\hline 2017 & 0.65 & 0.13 & 0.78 & 0.22 & 0.00 & 0.22 & 0.52 & 0.09 & 0.61 \\
\hline
\end{tabular}




\section{Bijlage 5 Betrouwbaarheidsintervallen van de relatie tussen het vangstsucces van de verhoogde boomkor en grote kuil}

In de openwatersurvey in het open water van het IJ ssel- en Markermeer is tot en met 2012 met een grote kuil gevist en in 2013 is overgestapt op de verhoogde boomkor (van der Sluis et al., 2014). In 2012 is een experiment uitgevoerd, om het vangstsucces van de verhoogde boomkor en de grote kuil te vergelijken. Hiervoor is simultaan met een verhoogde boomkor en een grote kuil gevist. Er zijn 43 trekken uitgevoerd. In deze bijlage zijn de relevante uitkomsten voor de vier schubvissoorten samengevat. Voor een uitgebreide beschrijving van het experiment, de statistische vergelijking en de resultaten, zie bijlage 2 in van der Sluis et al. (2016).

In figuur B.5.1 zijn voor snoekbaars en baars de geschatte relatie tussen het vangstsucces in de grote kuil en de verhoogde boomkor weergegeven. Voor brasem en blankvoorn waren de beschikbare gegevens niet voldoende om een soort-specifieke relatie te bepalen. Daarom is de relatie van een grotere groep vissen gebruikt, namelijk van alle demersale (voor brasem) en alle pelagische (voor blankvoorn) vissoorten (figuur B.5.2)

In de figuren is het vangstsucces van de 43 vergelijkende trekken geplot. De eenheden in deze figuren zijn dezelfde als gebruikt voor de survey-indices, namelijk kilogram per hectare. De rode lijn weerspiegelt de geschatte relatie tussen de twee tuigen (voor details over de gebruikte relatie, zie de volgende paragraaf). De rode stippellijnen weerspiegelen de $95 \%$ betrouwbaarheidsintervallen van de geschatte relatie. Voor alle vier soorten kan geen statistisch verschil in vangstsucces tussen de twee tuigen aangetoond worden, i.e. de 1 -op- 1 relatie valt binnen de $95 \%$

betrouwbaarheidsintervallen. Echter de onzekerheid van deze relatie is erg groot, met name voor hogere vangstsuccessen. Zie bijvoorbeeld baars: voor een vangstsucces van $15 \mathrm{~kg} / \mathrm{hectare}$ in de grote kuil is dus de aanname dat het vangstsucces in de verhoogde boomkor ook $15 \mathrm{~kg} / \mathrm{hectare}$ is. Echter, de betrouwbaarheidsintervallen laten zien dat het geschatte vangstsucces tussen $\sim 9$ en $\sim 20$ $\mathrm{kg} /$ hectare ligt.

\section{De geschatte relatie voor alle soorten}

Het vangstsucces in de kuil is omgezet naar het vangstsucces in de boomkor via de formule:

$$
\text { boomkor }=(\text { kuil }+0.3)^{\beta} \cdot e^{(\log (0,3) \cdot(1-90)}-0.3
$$

waarbij boomkor = het vangstsucces (biomassa per hectare) van de verhoogde 4-meter boomkor, kuil $=$ het vangstsucces (biomassa per hectare) in de grote kuil en $\beta$ zoals in tabel B.5.1.

Tabel B.5.1. De gekozen parameter $\beta$ voor de schubvissoorten gevangen binnen de openwatersurvey op het IJssel-en Markermeer. Voor het vangstsucces in gewicht ( $\mathrm{kg} / \mathrm{ha})$. De parameterwaarde is geschat per soort ('per soort') of geschat per groep soorten ('pelagisch'/'demersaal'). Bij de parameterschatting is de $95 \%$ betrouwbaarheidsinterval ('95\% Cl') berekend.

Soort

Baars

Blankvoorn

Brasem

Snoekbaars

\begin{tabular}{lll} 
& \multicolumn{3}{c}{$\mathrm{kg} / \mathrm{ha}$} & \\
& $\boldsymbol{\beta}$ & $\mathbf{9 5 \%} \mathbf{C l}$ \\
Per soort & 1 & $0.865-1.077$ \\
Pelagisch & 1 & $0.967-1.083$ \\
Demersaal & 1 & $0.910-1.006$ \\
Per soort & 1 & $0.740-1.052$
\end{tabular}




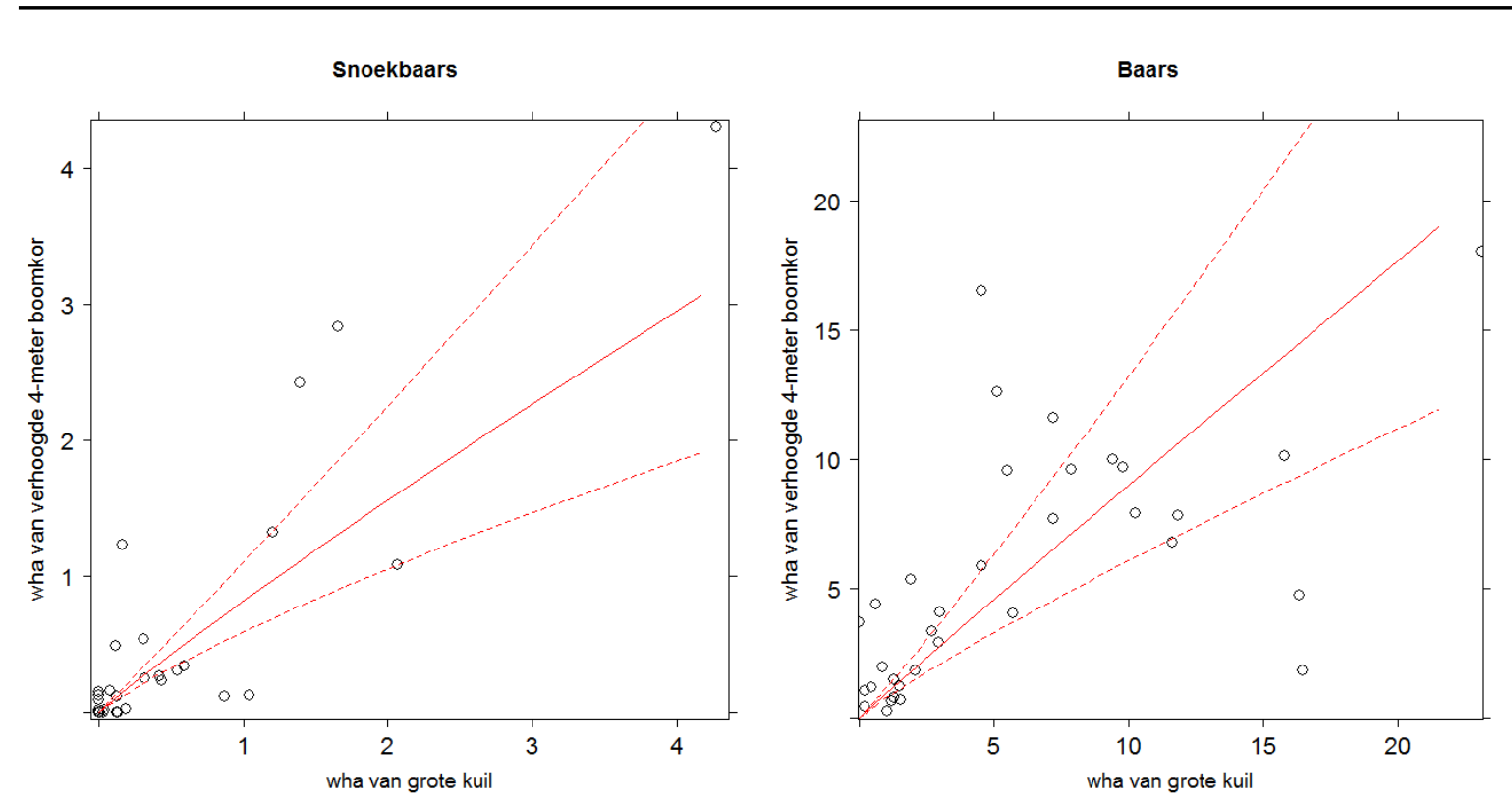

Figuur B.5.1. De geschatte relatie (rood doorgetrokken lijn) per soort tussen het vangstsucces ( $\mathrm{kg} /$ hectare) in de grote kuil en in de verhoogde boomkor. De 95\% betrouwbaarheidsintervallen uit het lineair model zijn weergegeven in rood gestippelde lijnen.
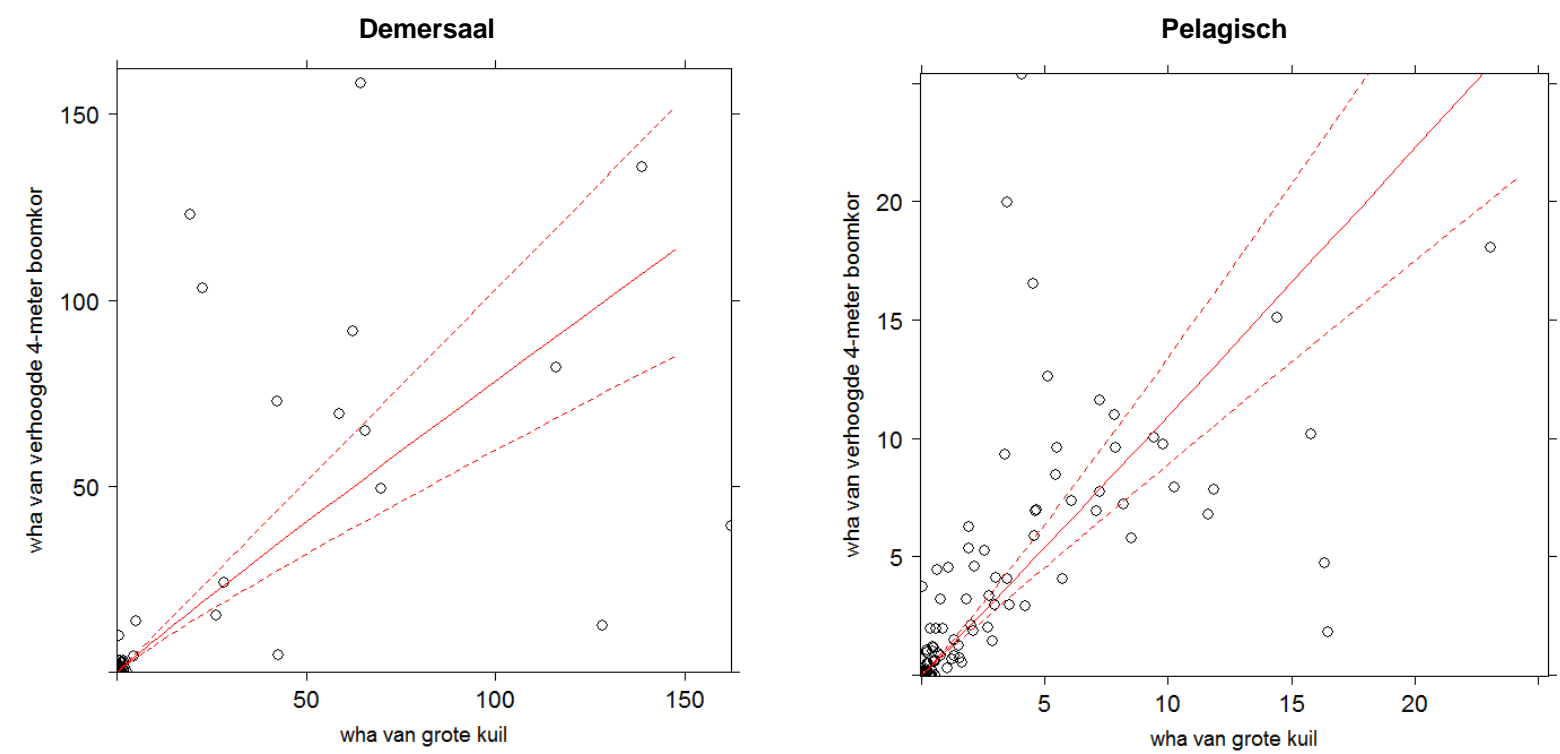

Figuur B.5.2. De geschatte relatie (rood doorgetrokken lijn) per soortgroep (demersaal of pelagisch) tussen het vangstsucces ( $\mathrm{kg} /$ hectare) in de kuil en in de boomkor. De 95\% betrouwbaarheidsintervallen uit het lineair model zijn weergegeven in rood gestippelde lijnen. De relatie voor de demersale vissoorten is gebruikt voor brasem, en de relatie voor de pelagische vissoorten voor blankvoorn. 


\section{Bijlage 6 Stock-recruitment analyses}

Bij lage dichtheden volwassen vissen wordt verwacht dat de dichtheid van de recruitment (0-jarigen) in het volgende jaar ook laag is. Immers als er weinig volwassenen zijn, dan zullen zij als geheel ook minder jongen kunnen produceren. Als de dichtheid aan volwassenen toeneemt, zal op een bepaald moment dit effect er niet meer zijn, omdat dichtheidsafhankelijke processen een rol gaan spelen. Een voorbeeld van zo een proces is voedselbeschikbaarheid; bij hogere dichtheden vis zal er te weinig voedsel beschikbaar zijn om alle jonge vis te voeden. Met andere woorden, er wordt in deze redenering aangenomen dat de omgeving draagkracht biedt voor een maximaal aantal nieuwe recruiten. Worden er meer jongen geproduceerd, dan sterft het surplus.

De relatie tussen de omvang van het paaibestand en die van de nieuwe generatie kan onderzocht worden met behulp van zogenaamde 'stock-recruitment' relaties. De omvang van het paaibestand waarbij nog net de maximum aanwas wordt gerealiseerd, wordt dan aangemerkt als 'limit reference point' (LRP). De hoogte van het LRP hangt af van de omstandigheden in de meren. Bij verschillende voedselomstandigheden of temperatuur, zal een LRP mogelijk een andere waarde hebben.

Deze stock-recruitment relatie kan worden gebruikt om iets over de staat van het bestand te zeggen (ICES Advice Technical Guidelines, 2017). Wanneer de paaibiomassa lager is dan het LRP, is er sprake van zogenaamd 'recruitment impairment'. Dit houdt in dat het paaibestand niet het aantal juvenielen kan produceren die het systeem aankan, waardoor potentieel herstel van het bestand wordt belemmerd. Ook zal er dan sowieso niet de maximale vangstcapaciteit (MSY) van het bestand worden bereikt. Daartegenover staat dat boven het LRP, fluctuaties in het paaibiomassa niet direct een negatief effect hoeven te hebben op de toekomst van het bestand.

Omdat we geen absolute schattingen van de hoeveelheid biomassa hebben (zoals berekend in een bestandschattingsmodel), wordt hier de stock-recruitment relatie onderzocht met dichtheidindices uit de openwatermonitoring. Dit is minder nauwkeurig, maar momenteel het beste dat beschikbaar is. Met deze indices wordt daarom geprobeerd de stock-recruitment relatie te schatten.

De relatie tussen de dichtheid 0 -jarigen (in aantallen) in het najaarsbestand wordt vergeleken met de dichtheid volwassen vis (in biomassa) in het jaar ervoor. Voor adulten wordt biomassa gekozen omdat grotere vis over het algemeen ook meer nakomelingen geeft dan kleinere exemplaren. Er worden drie mogelijke stock-recruitment relaties gefit, namelijk Beverton- Holt (Beverton \& Holt 1992), Ricker (Ricker 1954) en Segmented Regression (de zogenaamde 'hockeystick'). Beverton Holt gaat uit van een toename bij lage dichtheden waarna er langzaam een maximum wordt bereikt bij een bepaalde dichtheid. Het Ricker model gaat ervan uit dat bij hoge dichtheden, er minder recruitment is; de redenering hierachter is dat door voedselgebrek of andere processen (bijvoorbeeld kannibalisme) juvenielen een steeds kleinere kans op overleving hebben bij hoge dichtheden. Segmented regression gaat uit van een initiële lineaire stijging, waarna er een 'breakpoint' is, waarna er bij hogere paaibiomassa het aantal juvenielen gelijk blijft. Segmented regression is een vereenvoudigde stockrecruitment relatie; biologisch gezien zal een initiële lineaire toename, gevolgd door een maximum na het breakpoint, niet vaak voorkomen. Deze vorm verleent zich echter beter dan de andere stockrecruitment relaties voor het bepalen van de LRP. De stock-recruitment relaties zijn gefit in FLR, waarbij de fit van de drie modellen onderling is vergeleken in AIC.

$\mathrm{Er}$ is veel variatie in de sterfte van 0 -jarige vis voordat deze gevangen wordt in de survey. Daarnaast bevatten de berekende indices onnauwkeurigheden door de bemonsteringsopzet (zo kan bijvoorbeeld een periode met veel wind de vangstefficiëntie van een survey beïnvloeden). Daardoor is in het algemeen de fit van dit type stock-recruitment relaties vaak zwak. Of een stock-recruitment relatie goed genoeg is om een referentiepunt te schatten wordt binnen ICES meestal door middel van expert judgement bepaald. Daarbij geldt dat bij zeer variabele stock-recruitment relaties er ook gebruik kan worden gemaakt van andere kennis van het bestand. 


\section{Baars}

Bij baars is te zien dat - gemiddelde genomen - hoe hoger de biomassa van adulten hoe meer 0jarigen er zijn het jaar erna (figuur B.6.1). De beste fit voor baars is de Beverton-Holt (laagste AIC waarde), maar het verschil met Ricker is klein. Segmented regression gaf geen fit.

Een LPR komt niet direct voort uit een Beverton Holt stock-recruitment model, omdat de curve asymptotisch naar het maximum gaat en het dus nooit volledig bereikt. Bij Ricker ligt het LRP bij de piek, deze ligt rond de adulten-waarde van 11. Vanuit het Ricker model is dus de schatting, dat de biomassa van adulten in alle jaren lager is dan de biomassa waarbij de maximum aanwas wordt gerealiseerd (de LRP). Dit betekent dat de schatting is dat er dus vanaf 1992 al een risico is op recruitment impairment. De variatie in de datapunten is echter wel erg groot, wat de schatting onzeker maakt. Samenvattend geldt voor baars dat er signalen zijn dat in de huidige situatie een afnemend paaibestand kan leiden tot afnemende recruitment, wat een signaal is voor overbevissing (F>Fmsy).

Volgens deze gegevens was het paaibestand in 2015 zodanig laag dat de hoeveelheid daaruitvolgende recruiten niet maximaal was (i.e., recruitment impairment). In 2016 was het paaibestand echter hoog, en de hoeveelheid nieuwe recruiten ook (figuur B.6.1 links).
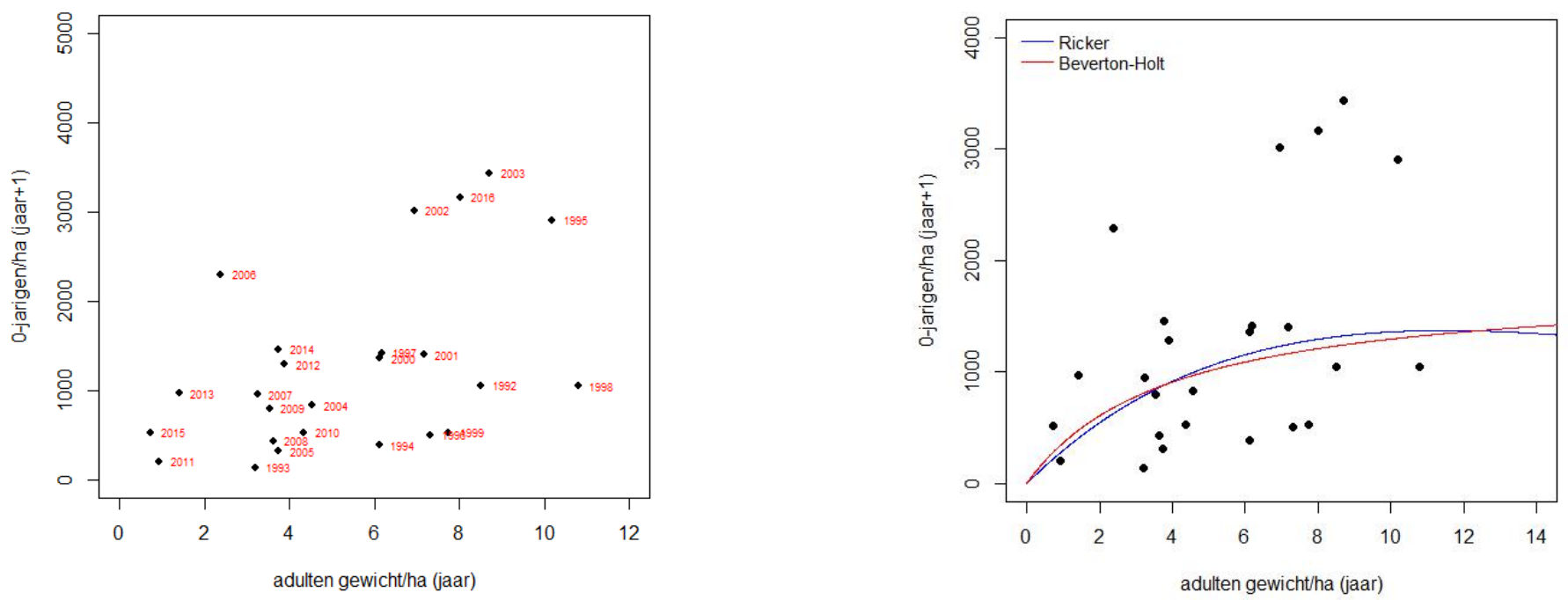

Figuur B.6.1 Stock-recruitment relatie voor baars. Relatie tussen de paaibiomassa in het huidige jaar en aantallen 0-jarigen in het jaar erna voor het IJ sselmeer en Markermeer gecombineerd (links: met de jaartallen, rechts met de gefitte relaties). Segmented regression gaf geen fit.

\section{Snoekbaars}

De paaibiomassa-index van snoekbaars is gebaseerd op zeer weinig individuen, soms maar enkele per jaar (bijlage 3). Dit maakt deze index zeer onzeker, waardoor deze niet wordt gebruikt voor vangstadviezen (Tien et al. 2017). Ook is er geen relatie tussen de leeftijden van jaar op jaar (bijlage 2 ), wat een aanwijzing is dat de gegevens niet goed genoeg zijn voor dit type analyses. Dit is ook te zien in de stock-recruitment relatie (figuur B.5.2); er is erg veel variatie in het aantal 0-jarigen bij een hele lage paaibiomassa. Zowel de hoogste recruitment als de laagste recruitment zijn te vinden bij de allerlaagste paaibiomassa-indices. Hierdoor is er geen goede stock-recruitment relatie te fitten. De gefitte relaties, Ricker en Segmented Regression, proberen de data zo goed mogelijk te fitten door zo snel mogelijk omhoog te gaan (Beverton-Holt gaf geen fit). Ook zijn er te weinig gegevens beschikbaar bij hogere paaibiomassa-indices. De conclusie is daarom dat de beschikbare gegevens niet geschikt zijn om de stock-recruitment relatie betrouwbaar te schatten. Door gebrek aan een goede stock-recruitment relatie is dus onbekend of er momenteel sprake is van recruitment impairment en zal dus als voorzorgsmaatregel opgepast moeten worden dat het paaibestand niet lager wordt. 

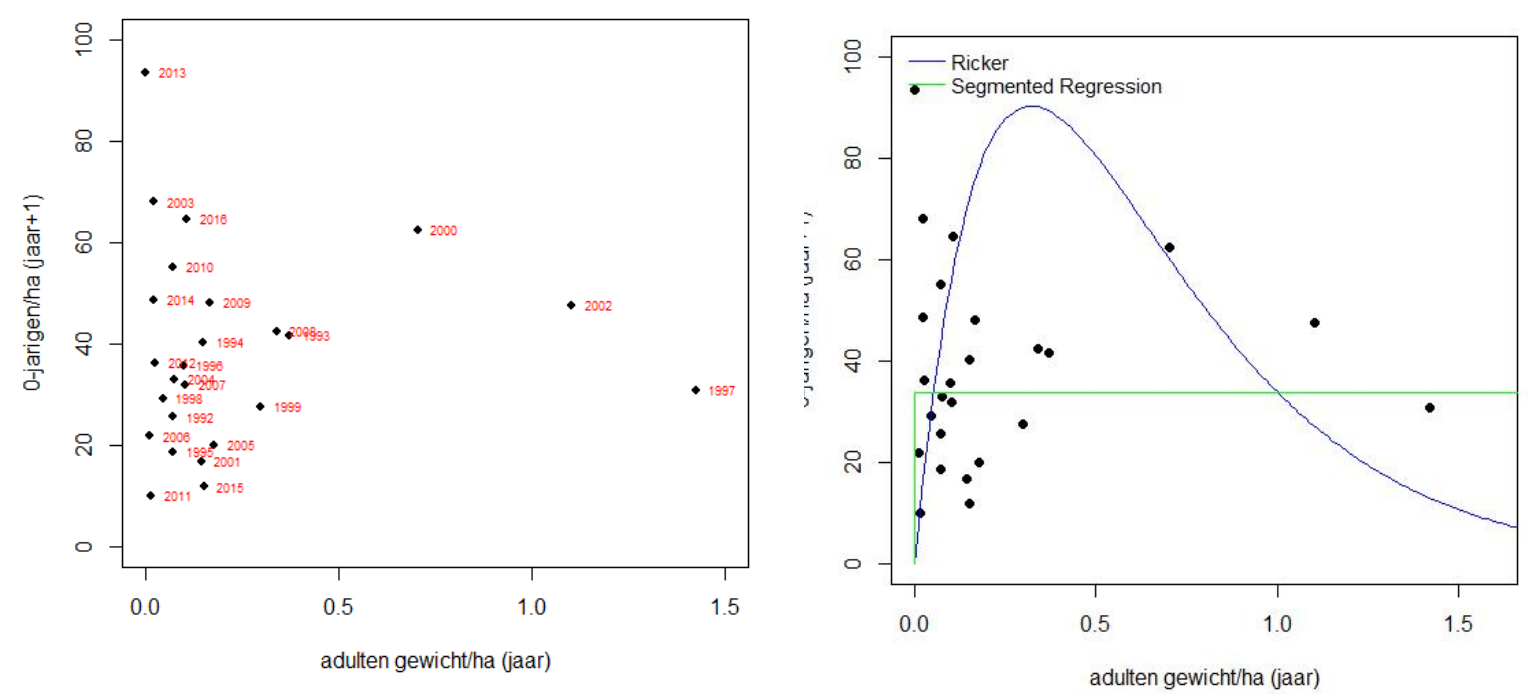

Figuur B.6.2 Stock-recruitment relatie voor snoekbaars. Relatie tussen de paaibiomassa in het huidige jaar en aantallen 0-jarigen in het jaar erna voor het IJ sselmeer en Markermeer gecombineerd. (links: met de jaartallen, rechts met de gefitte relaties). Beverton-Holt gaf geen fit.

\section{Blankvoorn}

Ook bij blankvoorn is te zien dat er erg veel variatie is in het aantal 0-jarigen bij een lage paaibiomassa. De hoogste index-waarde voor de 0 -jarigen ligt bij de één na hoogste paaibiomassawaarde en de hoogste paaibiomassa-index heeft één van de laagste index-waarden voor 0-jarigen. Ook zijn er te weinig gegevens bij hoge paaibiomassa-waardes. Ook voor blankvoorn geldt daardoor dat er geen goede stock-recruitment relatie te fitten is (Beverton-Holt gaf helemaal geen fit). Door gebrek aan een goede stock-recruitment relatie is dus onbekend of er momenteel sprake is van recruitment impairment en zal dus als voorzorgsmaatregel opgepast moeten worden dat het paaibestand niet lager wordt.
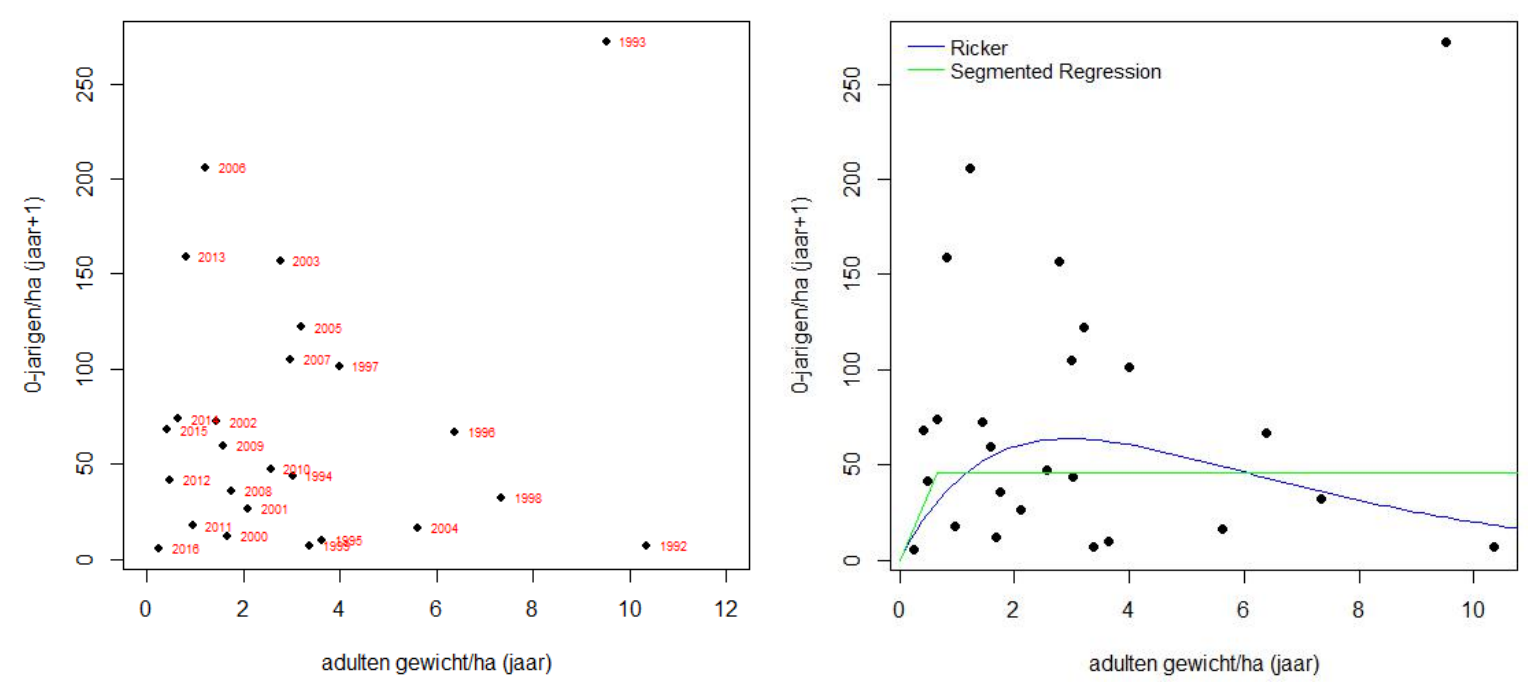
Figuur B.6.3 Stock-recruitment relatie voor blankvoorn. Relatie tussen de paaibiomassa in het huidige jaar en aantallen 0-jarigen in het jaar erna voor het IJ sselmeer en Markermeer gecombineerd. (links: met de jaartallen, rechts met de gefitte relaties). Beverton-Holt gaf geen fit.

\section{Brasem}

Ook bij brasem is te zien dat er erg veel variatie is in het aantal 0-jarigen bij alle paaibiomassa's (figuur B.6.4) en dat ook hier dus geen goede stock-recruitment relatie is te schatten. Het hoogste punt in paaibiomassa gaf een zeer lage 0 -jarige index, terwijl het één na hoogste punt in paaibiomassa de hoogste recruitment-index gaf. De gefitte relaties, Ricker en Segmented Regression geven geen goede fit (Beverton-Holt gaf geen fit). Door gebrek aan een goede stock-recruitment relatie is dus onbekend of er momenteel sprake is van recruitment impairment en zal dus als voorzorgsmaatregel opgepast moeten worden dat het paaibestand niet lager wordt.
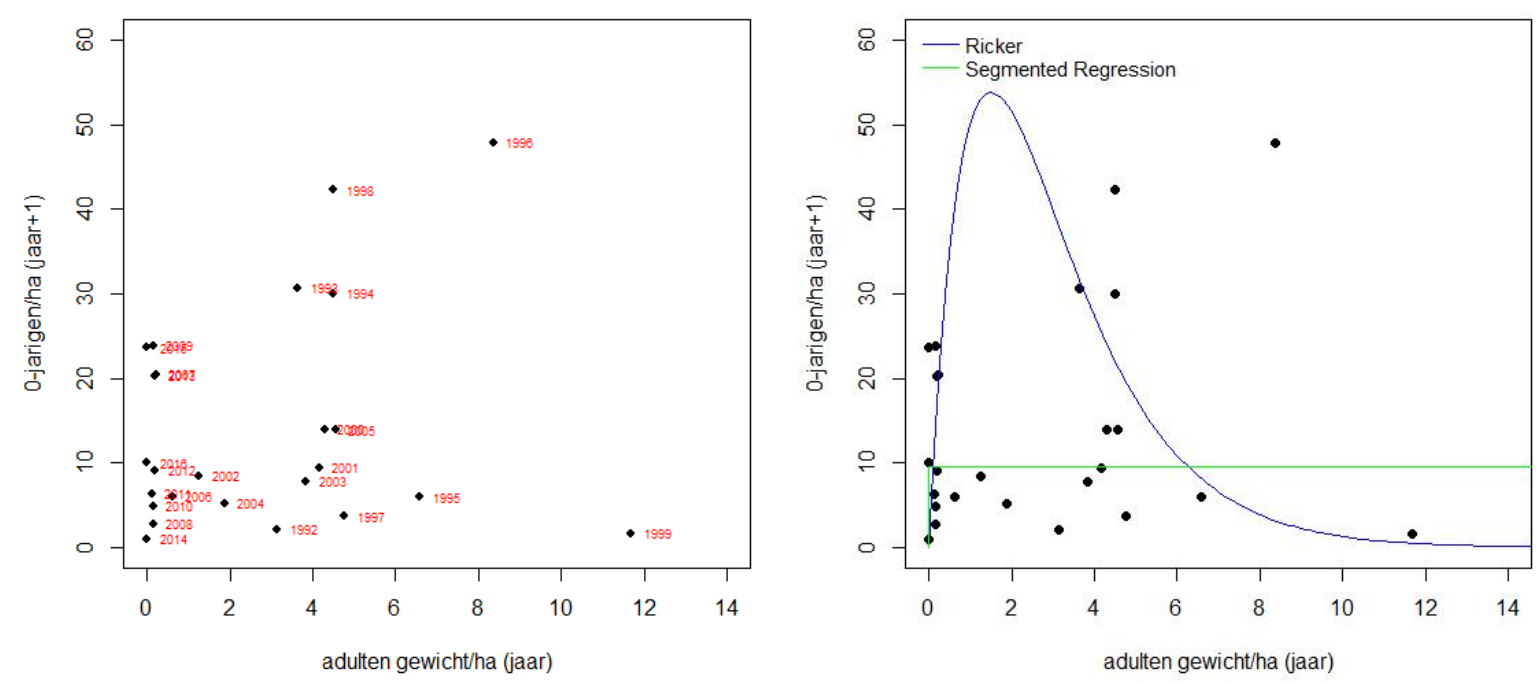

Figuur B.6.4 Stock-recruitment relatie voor brasem. Relatie tussen de paaibiomassa in het huidige jaar en aantallen 0-jarigen in het jaar erna voor het IJ sselmeer en Markermeer gecombineerd. (links: met de jaartallen, rechts met de gefitte relaties). Beverton-Holt gaf geen fit. 


\section{Bijlage 7 Aanlandingen vs survey-index}

Vanuit de beroepsvissers zijn signalen gekomen dat de trends zoals aangetroffen in de surveygegevens niet overeenkomen met de trends die de vissers in hun aanlandingen zien. Om dit te onderzoeken zijn de aanlandingen en de surveygegevens met elkaar vergeleken. De vraag hierbij is of de trend in de survey, wat betreft de paaibiomassa, overeenkomsten vertoont met de trend in de aanlandingen.

I dealiter zouden de surveygegevens met het commercieel vangstsucces (de vangsten per eenheid inspanning) worden vergeleken, waardoor er rekening zou worden gehouden met verschillen in inspanning tussen jaren. Er is echter momenteel geen tijdreeks van de inspanning beschikbaar. Van vangsten is er momenteel alleen een dataset beschikbaar van de aanlandingen zoals geregistreerd door vissers bij de PO vanaf het jaar 2000: de PO-aanlandingsregistratie. Hierbij mist in ieder geval de niet-aangelande vangst (de discards). Daarnaast mist waarschijnlijk van brasem en blankvoorn een beduidend deel van de aanlandingen (Schram et al. in prep.). Ook zijn de brasemaanlandingen in de PO-aanlandingsregistratie opgesplitst in 'brasem' en 'blei', waarbij de tweede een verzamelnaam is voor de vangsten van brasem, kolblei en hun hybride. Voor snoekbaars en baars is de inschatting dat de PO-aanlandingsregistratie de werkelijkheid qua aanlandingen redelijk goed beschrijft.

Doordat de inspanning niet bekend is, kan de surveytrend alleen vergeleken worden met de trend in de absolute hoeveelheid aanlanding, zoals geregistreerd bij de PO - waarbij de gegevens van blankvoorn en vooral brasem dus door veel onzekerheid omgeven zijn. De aanlandingen van snoekbaars, baars, blankvoorn en brasem/kolblei worden uitgezet tegen de survey-index voor het paaibestand, zoals ook gebruikt in hoofdstuk 3-6. Hierbij worden 2016 en 2017 niet meegenomen in de analyse, omdat een beduidend deel van de vissers in die jaren niet zijn opgenomen in de POaanlandingsregistratie.

\section{Baars}

De PO-aanlandingen laten grofweg een zelfde trend zien als de survey-index van het paaibestand van baars (figuur B.7.1). Beide tonen een afname vanaf het begin van de tijdreeks. In de aanlandingen lijkt er een dieptepunt te liggen in 2012, waarna de aanlandingen weer licht stijgen. De surveyindex fluctueert daarentegen sterk in de laatste jaren, op een relatief laag niveau.

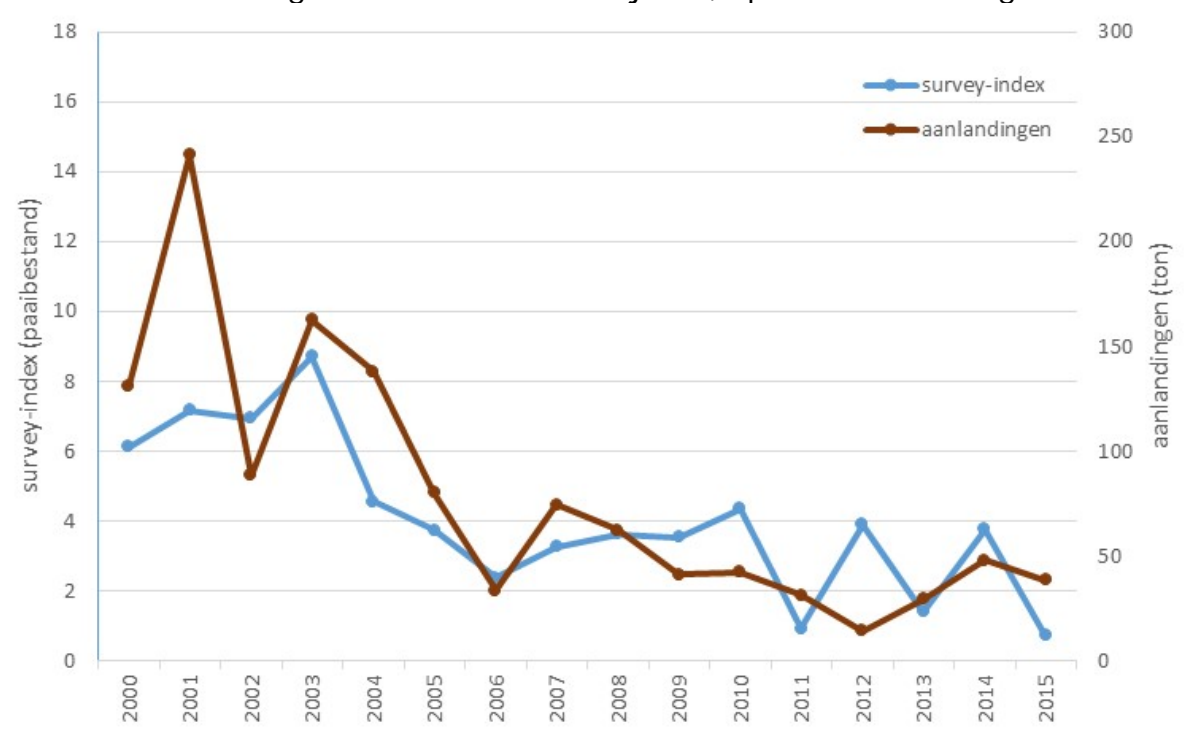

Figuur B.7.1 Vergelijking van de ontwikkeling in de biomassa-index voor het paaibestand (blauw) en in de aanlandingen zoals bijgehouden door de PO (rood), voor baars. De aanlandingen zijn van een kalenderjaar, de biomassa-index is zoals bepaald in de openwatermonitoring in oktober-november. 


\section{Snoekbaars}

De PO-aanlandingen laten eenzelfde trend zien door de jaren heen, als de survey-index van het paaibestand van snoekbaars (figuur B.7.2). Voor 2004 zijn er iets grotere verschillen, omdat de paaiindex sterk fluctueert, maar wel op een relatief hoog niveau - zoals ook de aanlandingen relatief hoog zijn. Vanaf 2004 lopen de trends gelijk op. Zowel de index als de aanlandingen laten een dieptepunt zien in 2011-2014, gevolgd door een toename in 2015. De sterke overeenkomst is opmerkelijk, aangezien de survey-index voor het paaibestand door veel onzekerheid is omgeven. Het versterkt daarom de voorzichtige signalen zoals aangetroffen in de survey, dat de hoeveelheid oudere snoekbaars sinds 2015 lijkt toe te nemen.

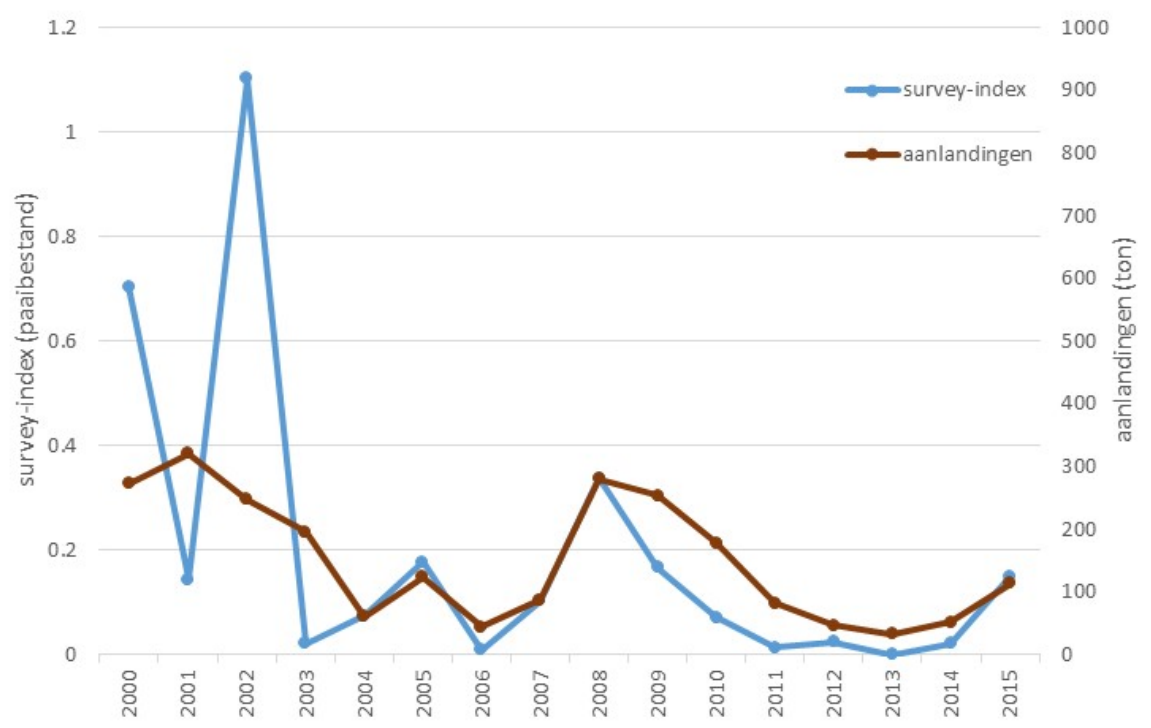

Figuur B.7.2 Vergelijking van de temporele ontwikkeling in de biomassa-index voor het paaibestand (blauw) en in de aanlandingen zoals bijgehouden door de PO (rood), wat betreft snoekbaars. Aanlandingen van het kalenderjaar, biomassa-index zoals bepaald in de openwatermonitoring in oktober-november.

\section{Blankvoorn}

De PO-aanlandingsregistratie voor blankvoorn is pas in 2007 begonnen. Deze aanlandingen laten eenzelfde trend zien als de survey-index wat betreft het paaibestand van blankvoorn (figuur B.7.3). De aanlandingen nemen consistent af, wat overeenkomt met de afname in de survey-index. De aanlandingen nemen hierbij nog consistenter van jaar op jaar af, dan de survey-index. De overeenkomst tussen aanlandingen en surveyvangsten is opmerkelijk, aangezien de blankvoornaanlandingen in de PO-dataset waarschijnlijk een onderschatting is van de daadwerkelijke hoeveelheid aanlandingen (zie inleiding). Wellicht is deze onderschatting vrij constant door de jaren heen geweest. 


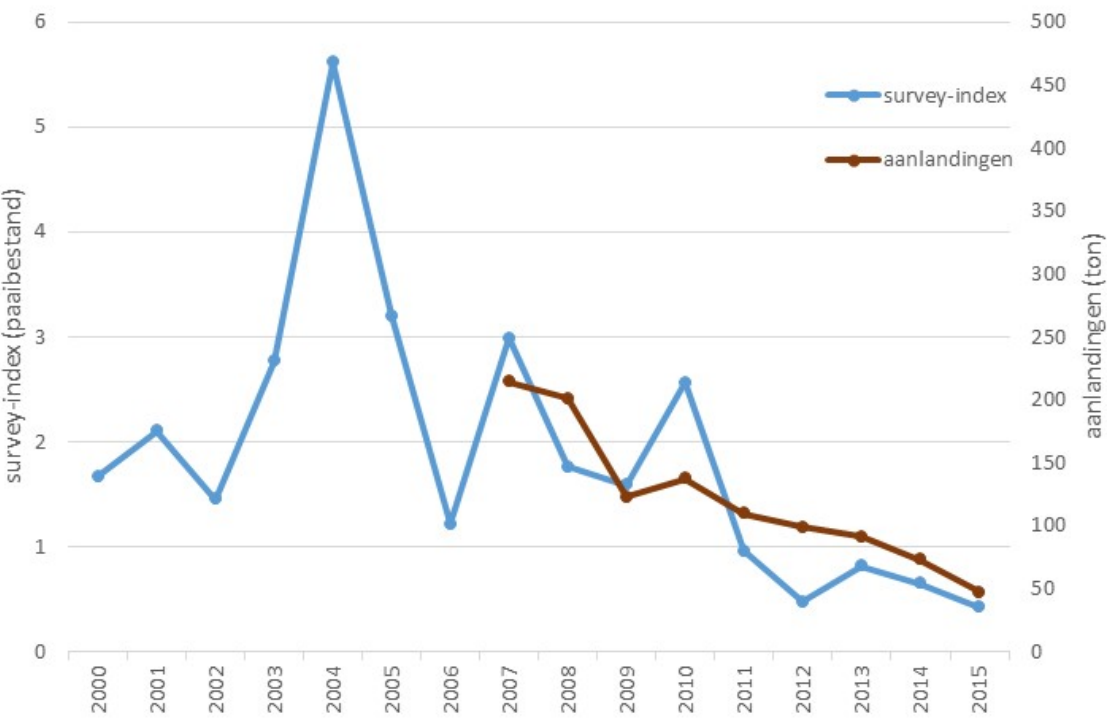

Figuur B.7.3 Vergelijking van de temporele ontwikkeling in de biomassa-index voor het paaibestand (blauw) en in de aanlandingen zoals bijgehouden door de PO (rood), wat betreft blankvoorn. Er zijn pas sinds 2007 gegevens over de blankvoornaanlandingen. Aanlandingen van het kalenderjaar, biomassa-index zoals bepaald in de openwatermonitoring in oktober-november.

\section{Brasem}

Wat betreft de brasemaanlandingen van de vissers is de representativiteit van de PO-statistieken waarschijnlijk laag (zie de inleiding). De aanlandingen laten ook niet dezelfde trend zien als de surveyindex (figuur B.7.4). De survey laat een sterke brasemafname in 2006 zien, gevolgd door een vrij consistente maar minder grote afname tussen 2006 en 2015. De PO-aanlandingen nemen toe tot aan 2006, en nemen daarna af in 2007-2015. De totale aanlandingen door de visserij laten dus niet dezelfde ontwikkelingen door de tijd zien, als de surveyvangsten. Dit is niet opmerkelijk, aangezien de brasemaanlandingen in de PO-dataset waarschijnlijk slecht overeenkomen met de daadwerkelijke brasemaanlandingen zijn (zie inleiding).

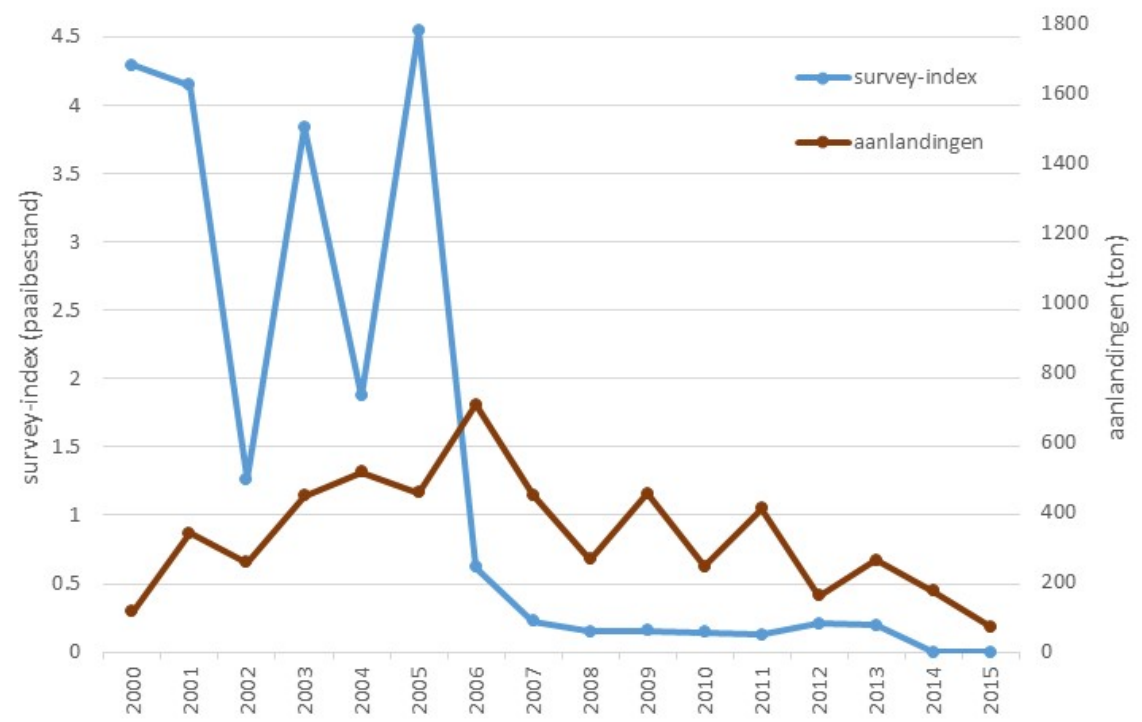

Figuur B.7.4 Vergelijking van de temporele ontwikkeling in de biomassa-index voor het paaibestand (blauw) en in de aanlandingen zoals bijgehouden door de PO (rood), wat betreft brasem. Het betreft de PO gegevens voor 'brasem' en voor 'blei'. Blei is in deze statistieken een verzamelnaam voor brasem, kolblei en hun hybride. Aanlandingen van het kalenderjaar, biomassa-index zoals bepaald in de openwatermonitoring in oktober-november. 
Wageningen Marine Research

T: $+31(0) 317480900$

E: marine-research@wur.nl

www.wur.nl/marine-research

Visitors address

- Ankerpark 271781 AG Den Helder

- Korringaweg 7, 4401 NT Yerseke

- Haringkade 1, 1976 CP IJ muiden
Wageningen Marine Research is the Netherlands research institute established to provide the scientific support that is essential for developing policies and innovation in respect of the marine environment, fishery activities, aquaculture and the maritime sector.

Wageningen University \& Research is specialised in the domain of healthy food and living environment.

\section{The Wageningen Marine Research vision:}

'To explore the potential of marine nature to improve the quality of life.'

The Wageningen Marine Research mission

- To conduct research with the aim of acquiring knowledge and offering advice on the sustainable management and use of marine and coastal areas.

- Wageningen Marine Research is an independent, leading scientific research institute.

Wageningen Marine Research is part of the international knowledge organisation Wageningen UR (University \& Research centre). Within Wageningen UR, nine specialised research institutes of Stichting Wageningen Research (a Foundation) have joined forces with Wageningen University to help answer the most important questions in the domain of healthy food and living environment. 